\title{
Late Early Permian (late Leonardian; Kungurian) algae, microproblematica, and smaller foraminifers from the Yeso Group and San Andres Formation (New Mexico; USA)
}

\author{
Daniel Vachard, Karl Krainer, and Spencer G. Lucas
}

\begin{abstract}
Six new species of algae and microproblematica, three new genera and nine new species of smaller foraminifers are described in the late Early Permian (= late Cisuralian = Kungurian = late Leonardian) strata of the Yeso Group and San Andres Formation in New Mexico (USA). These are four algae Boueina? tubulata n. sp., B.? crassundia n. sp., Gymnocodium? johnsonii n. sp., G.? bacillum n. sp.; two microproblematica Ellesmerella rara n. sp., and Tubiphytes epimonellaeformis n. sp.; four globivalvulinoid foraminifers Globivalvulina parapiciformis n. sp., G. retroseptata n. sp., G. novamexicana n. sp., and G. praegraeca n. sp.; and five miliolate foraminifers Orthovertellopsis proteaeformis n. gen. n. sp., O. calcitornellaeformis n. gen. n. sp., Olgaorlovella davydovi n. gen. n. sp., Glomomidiella infrapermica n. sp., and Praeneodiscus convexus n. gen. n. sp. The Yeso Group and San Andres Formation are subdivided into six Kungurian/late Leonardian biozones. This accurate biozonation permits a better correlation of the Leonardian regional stage of Northern America, especially in New Mexico, and its comparison with the international Kungurian stage. Furthermore, the new taxa are important for reconstructing the phylogeny of Miliolata, and for correlating more accurately the series of North America, the Ural Ocean and Tethys.
\end{abstract}

Daniel Vachard. Collegial and International Research Centre of Active Seniors (CIRCAS), 1 rue des Tilleuls, 59152 Gruson, France Daniel.Vachard@free.fr

Karl Krainer. Institute of Geology and Paleontology, University of Innsbruck, 6020 Innsbruck, Austria Karl.Krainer@uibk.ac.at

Spencer G. Lucas. New Mexico Museum of Natural History, 1801 Mountain Road N.W., Albuquerque, 87104 New Mexico, USA spencer.lucas@state.nm.us

Keywords: Early Permian; Algae; Foraminifers; new genus; new species; New Mexico

http://zoobank.org/76D74301-4F2F-4A01-ADE5-EF52F8B53659

PE Article Number: 18.1.21A

Copyright: Palaeontological Association April 2015

Submission: 13 September 2013. Acceptance: 29 March 2015

Vachard, Daniel, Krainer, Karl, and Lucas, Spencer G. 2015. Late Early Permian (late Leonardian; Kungurian) algae, microproblematica, and smaller foraminifers from the Yeso Group and San Andres Formation (New Mexico; USA). Palaeontologia Electronica 18.1.21A: 1-77

palaeo-electronica.org/content/2015/1160-kungurian-of-new-mexico 


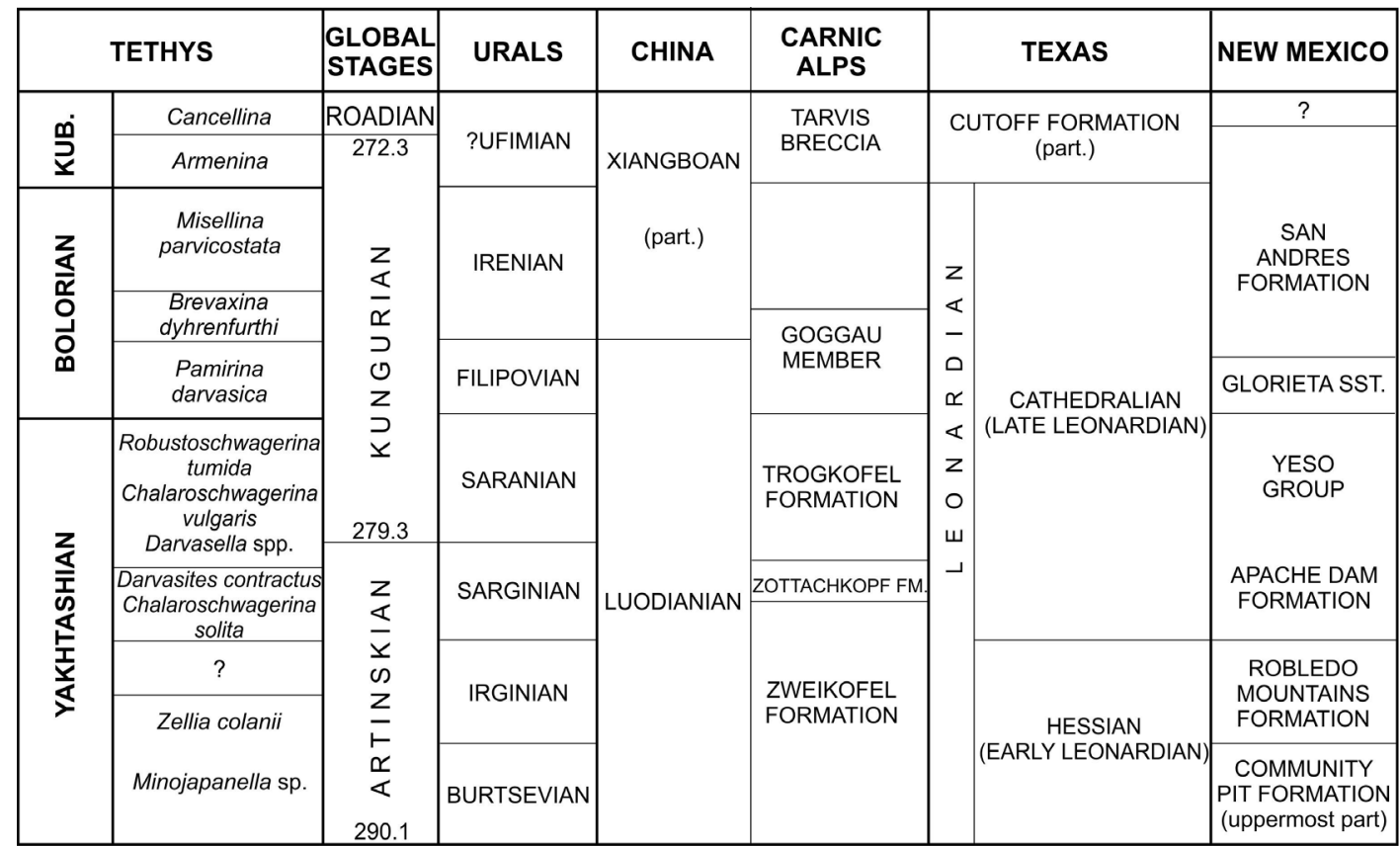

FIGURE 1. Stratigraphical nomenclature and correlations of the Artinskian, Kungurian, and Roadian (partim) interval (based on Ross and Ross, 1995; Henderson et al., 2012; Davydov et al., 2013; Lucas et al., 2015 modified). Abbreviations: KUB = Kubergandian; part. = partim (partially; in Latin); SST. = Sandstone; sp. = undetermined species; spp. = several undetermined species. Numbers $272.3,279.3$, and 290.1 represent radiometric ages in million years according to Henderson et al. (2012).

\section{INTRODUCTION}

Although the Late Pennsylvanian-Early Permian (i.e., Virgilian-Wolfcampian) fusulinids are well known in New Mexico (e.g., Thompson, 1948, 1964; Wilde, 1990, 2006; Vachard et al., 2012, 2013a with references therein), the late Early Permian (= Leonardian) assemblages of smaller foraminifers and algae remain poorly investigated (Krainer et al., 2009; Brose et al., 2013; Lucas et al., 2013a, 2013b, 2013c, 2015; Vachard et al., 2013b). In general, the Leonardian regional stage is less known than the other Permian stages in the USA (Dunbar et al., 1960; Ross, 1960, 1962, 1986, 1995; Magginetti et al., 1988; Fichten et al., 1995; Davydov, 1996; Davydov et al., 1997; Ross and Ross, 2003; Stevens and Stone, 2007); and in all of the Americas (Johnson and Kaska, 1965; PérezRamos, 1992; Vachard et al., 1997; 2000a, 2000b, 2000c; Groves, 2000; Pérez-Ramos and Nestell, 2002). The equivalents of the Leonardian are the Artinskian and Kungurian of the Ural Mountains in Russia (e.g., Chuvashov et al., 1990; Anfimov et al., 1991); two stages which are now the international references in chronostratigraphy. The Tethyan equivalents are Yakhtashian and Bolorian (Leven, 1992, 1993, 2003); the Chinese regional names are Luodianian and Xiangboan (= early Chi- hsian = early Qixaian) (Tong and Shi, 2000; Wang and Jin, 2000; Zhang et al., 2003; Yang et al., 2004) (Figure 1). This paper intends to: 1) describe a rich microflora of calcareous algae and microfauna of smaller foraminifers with interesting transitional forms, recently recovered from the late Early Permian Yeso and San Andres strata in central New Mexico; 2) document a rich microflora of codiaceans and gymnocodiaceans, as well as rare carbonate microproblematica, the zoological or botanical affinities (and consequently, the taxonomy) of which continue to be discussed: tuberitinids (or tuberitinaceans), tubiphytidids (or tubiphytaceans), and ellesmellerids (or ellesmeraceans); 3) document various species of globivalvulinid, miliolate and nodosariate smaller foraminifers; and 4) try to provide biostratigraphic and palaeobiogeographic inferences.

\section{HISTORICAL BACKGROUND}

The Leonardian of the USA was divided into three fusulinid biozones by Wilde (1990), from bottom to top: 1) PL1: zone of Schwagerina (now Praeskinnerella) crassitectoria (Dunbar and Skinner, 1937); 2) PL2: zone of transitional Parafusulina; 3) PL3: middle zone of Parafusulina. According to Wilde (1990), PL1 is well represented 


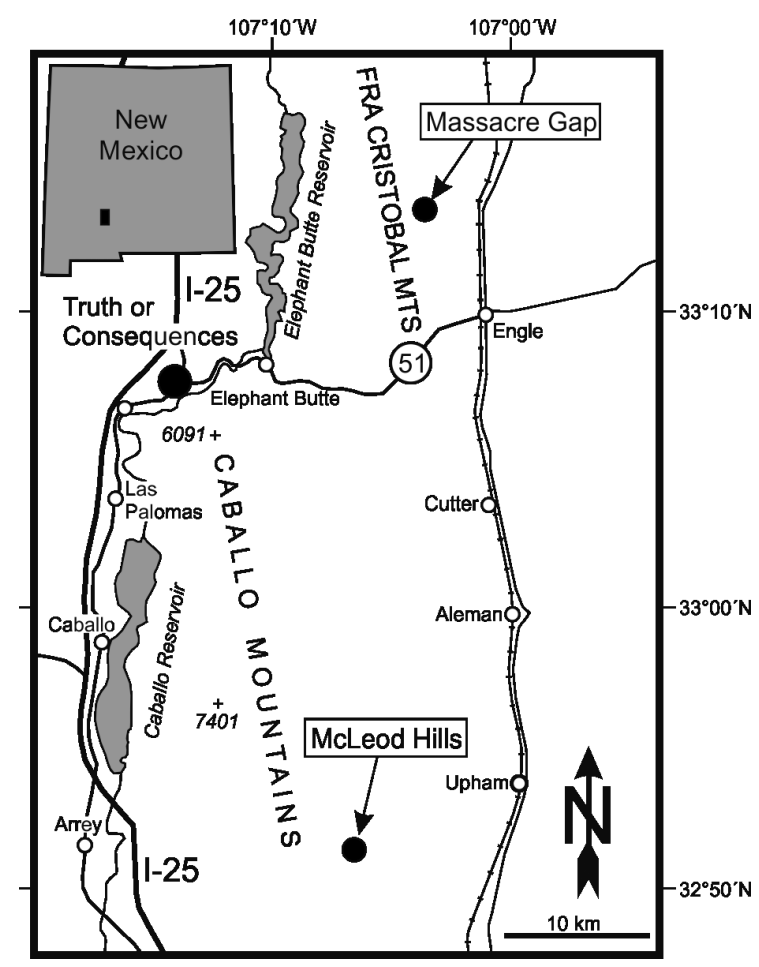

FIGURE 2. Location map of the Yeso Group sections at Massagre Gap and in the McLeod Hills, Sierra County (New Mexico) (after Lucas and Krainer, 2012 and Krainer et al., 2012, slightly modified).

by the lower Bone Spring Formation in the Delaware Basin, whereas its upper part corresponds to the lower part of the Yeso Group. The biozone PL2 is represented by the middle Bone Spring Formation and the middle Yeso shales and carbonates. The biozone PL3 corresponds to the upper Bone Spring Formation and the upper part of the Yeso Group. Moreover, PL3 contains the first Boultonia (now Ogbinella) guadalupensis Skinner and Wilde, 1954, which were encountered in the subsurface in the San Andres Formation (Wilde, 1990). These three biozones are considered to be either Artinskian and Kungurian (Ross and Ross, 1987, 1995; Vachard et al., 1997, 2000c) or parts of both stages (i.e., late Artinskian to early late Kungurian according to Davydov et al., 2013); the first two parts correspond to the Hessian regional substage and the last one to the Cathedralian substage. A zone of Chalaroschwagerina hawkinsi (Dunbar and Skinner, 1937) is occasionally added at the base of the Leonardian.

No biozonations with smaller foraminifers have been established in the Leonardian beds, and, in general, the knowledge of these groups is very poor in the Americas. References are more numerous in the Urals (Morozova, 1949; Grozdilova, 1956; Zolotova and Baryshnikov, 1980; Baryshnikov et al., 1982; Chuvashov et al., 1990) and other regions of the former USSR (Filimonova, 2008,2010 ), as well as in the Arctic islands of Norway and Canada (Sosipatrova, 1972; Groves and Wahlman, 1997; Pinard and Mamet, 1998; Blazejowski, 2009).

\section{MATERIAL AND METHODS}

\section{Yeso Group}

We studied the Yeso Group in the southern Fra Cristobal Mountains where a complete section is exposed at Massacre Gap and in the McLeod Hills of the southern Caballo Mountains, where a complete section is present but poorly-exposed, both in Sierra County, New Mexico (Figure 2).

In southern New Mexico, the Lower Permian Yeso Group is divided into the Arroyo de Alamillo Formation and the overlying Los Vallos Formation. The Los Vallos Formation is further divided into the (ascending order) Torres, Cañas and Joyita members (Lucas et al., 2005, 2013b; Lucas and Krainer, 2012). The Yeso Group (Figure 3) is underlain by nonmarine redbeds of the Abo Formation and overlain by strata of the eolian and shallow marine Glorieta Sandstone or the marine San Andres Formation (Figures 4, 5, 6).

At Massacre Gap in the Fra Cristobal Mountains (Figure 2), the Torres Member is approximately $134 \mathrm{~m}$ thick and composed of dolomite, gypsiferous siltstone, gypsum and siltstone to finegrained sandstone (see details in Lucas and Krainer, 2012). The succession is composed of six transgressive-regressive cycles marked by six intervals of dolomite separated by thicker intervals composed of siltstone, gypsiferous siltstone, gypsum and minor carbonate and sandstone beds. Dolomite is present as bedded to massive, and is locally indistinctly laminated. Calcareous algae and foraminifers were recognized in dolomite horizons 2 and 4 . In dolomite horizon 2, algae and foraminifers occur in an oncoidal floatstone to rudstone, composed of oncoids up to $6 \mathrm{~mm}$ in diameter, coated grains and fossil fragments including skeletons of bivalves and brachiopods, gastropods, foraminifers, ostracods, crinoids and calcareous algae (sample MG 10). In dolomite horizon 4, an intercalated dolomitized wackestone is composed of peloidal matrix with bivalves, gastropods, ostracods, crinoids, foraminifers and calcareous algae. In dolomite horizon 4, there are also thin intercalated rudstone layers (coquina) composed of abun- 


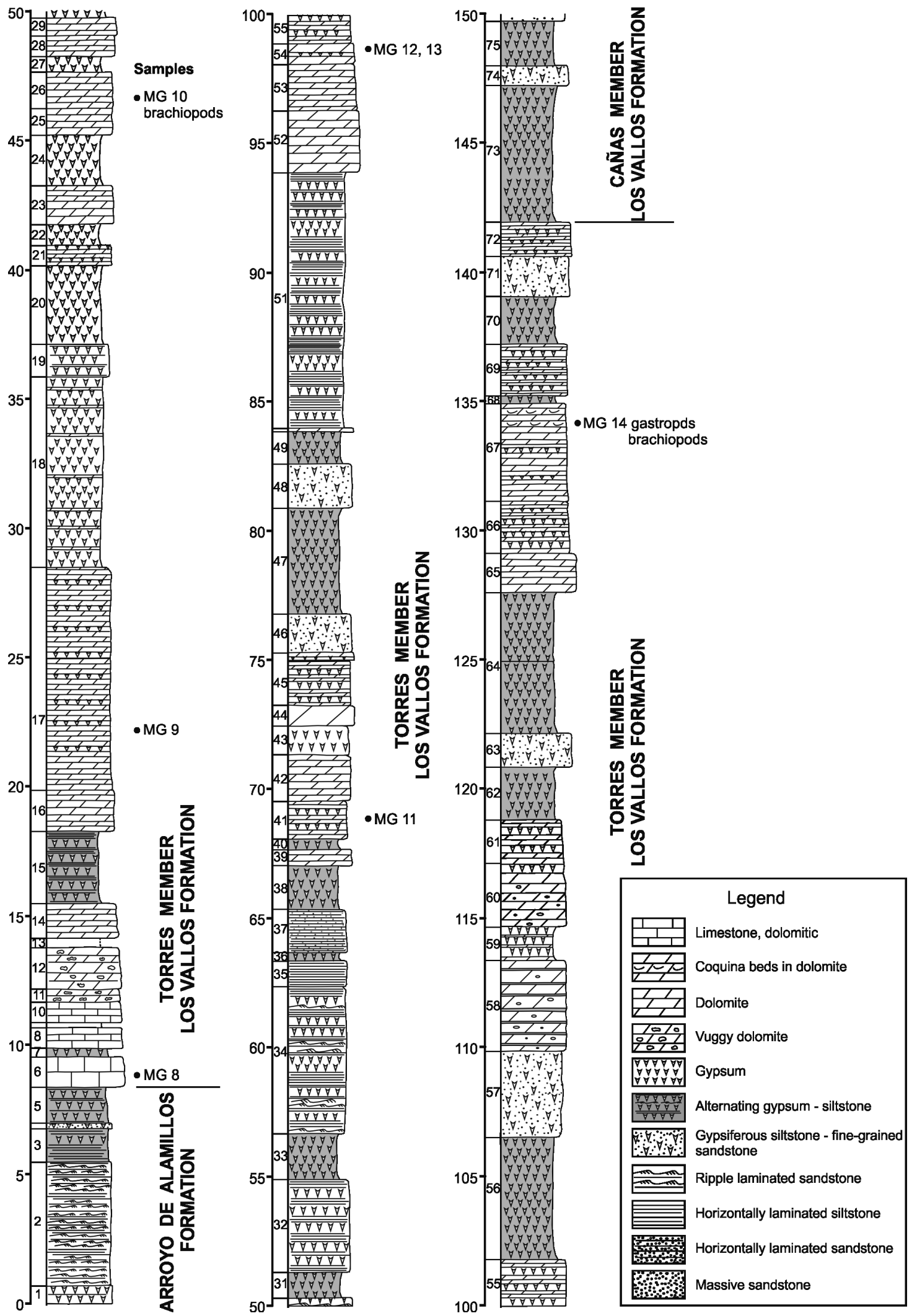

FIGURE 3. Lithostratigraphic columns of the Group at Massacre Gap with ticknesses (in $\mathrm{m}$ ) and sample MG locations (after Lucas and Krainer, 2012 and Krainer et al., 2012, slightly modified). 


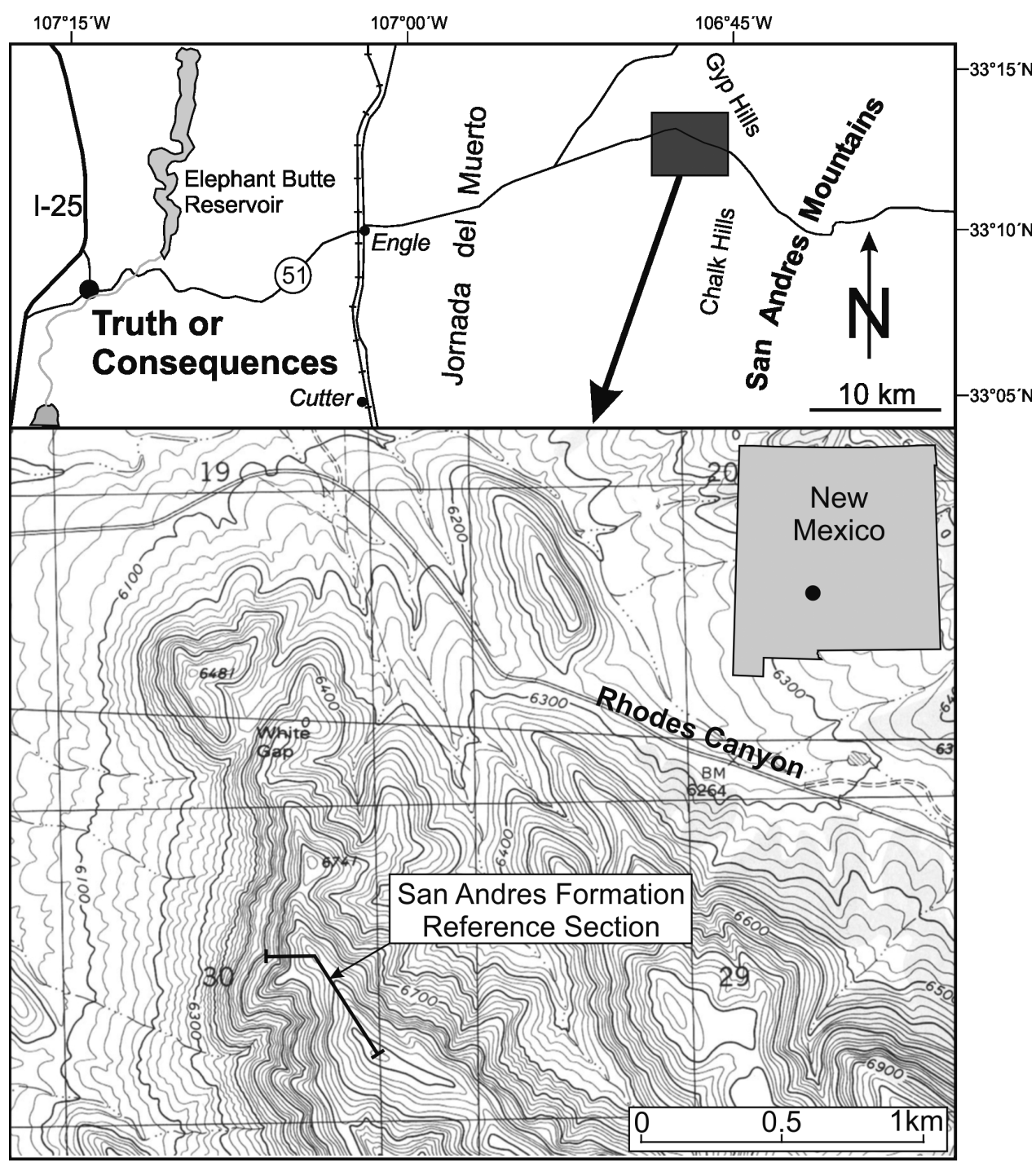

FIGURE 4. Location map of San Andres Formation at the reference section in the San Andres Mountains. After Krainer et al. (2012) (slightly modified).

dant bivalve and brachiopod fragments, minor amounts of gastropods and ostracods, and rare fragments of crinoids and calcareous algae (samples MG 12-13).

The dolomite horizon in the middle of the Torres Member in the McLeod Hills of the southern Caballo Mountains contains mudstone to wackestone composed of peloidal micrite and a poorly diversified fossil assemblage of locally abundant ostracods, crinoids and a few smaller foraminifers (Lucas and Krainer, 2012) (samples MLY 1-2). Dolomite of the Torres Member was deposited in a shallow marine, mostly restricted environment indicated by the low-diversity fossil assemblage. In this probable coastal sabkha, partly evaporitic conditions prevailed. Rare normal marine incursions into the sabkha provide diversified fossil assemblages, whereas some coquina layers may represent storm layers (tempestites) (for details, see Lucas and Krainer, 2012).

\section{San Andres Formation}

The San Andres Formation was studied at the reference section in the northern San Andres Mountains, approximately $1.6 \mathrm{~km}$ west of the type section near Rhodes Canyon, Sierra County, and in the McLeod Hills of the southern Caballo Mountains New Mexico (Figures 2, 4).

The reference section of the San Andres Formation, exposed in the northern San Andres Mountains, is approximately $130 \mathrm{~m}$ thick (Figure 5). 

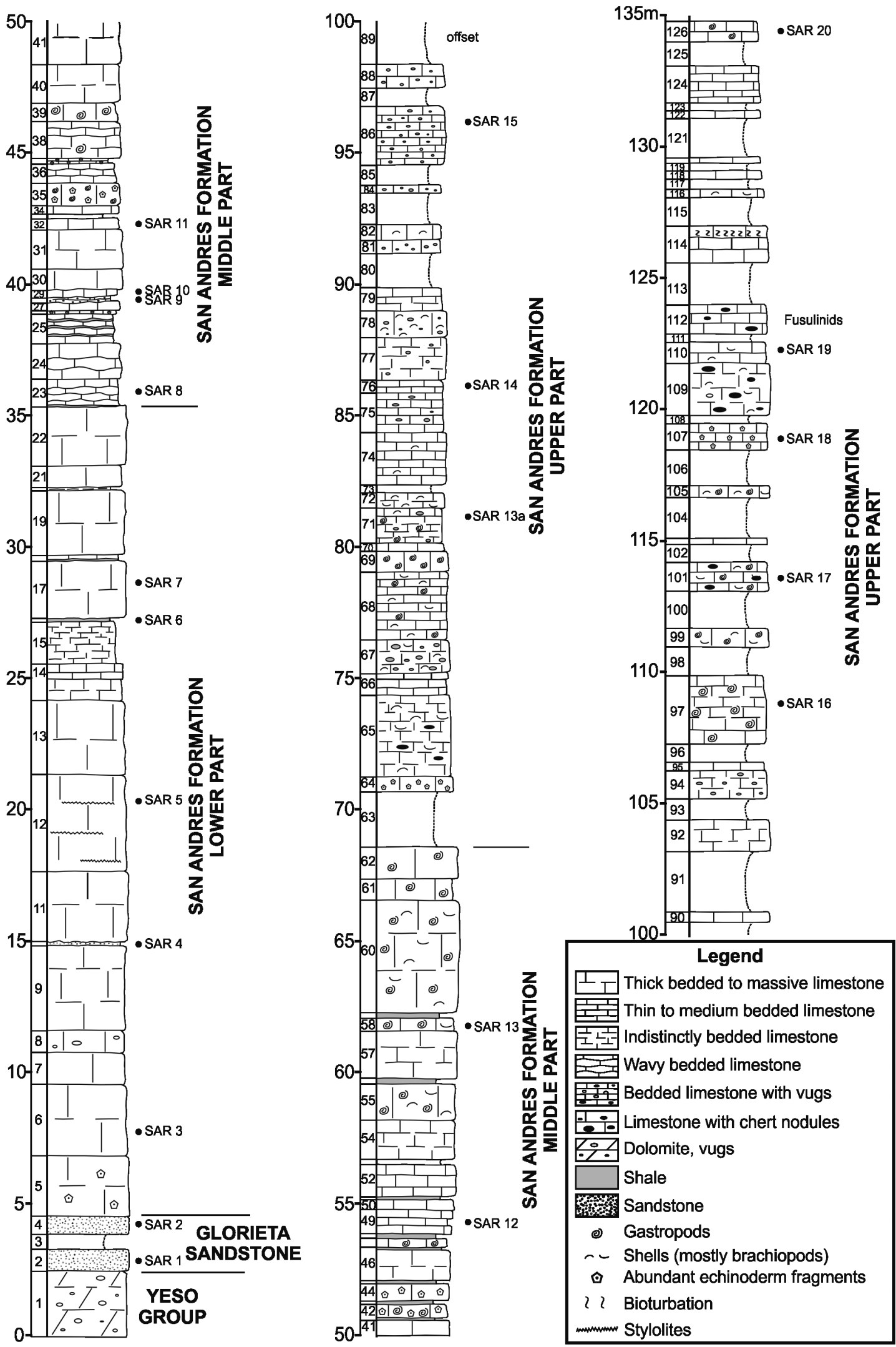

FIGURE 5. Stratigraphic columns of the San Andres Formation with thicknesses and sample SAR locations. 


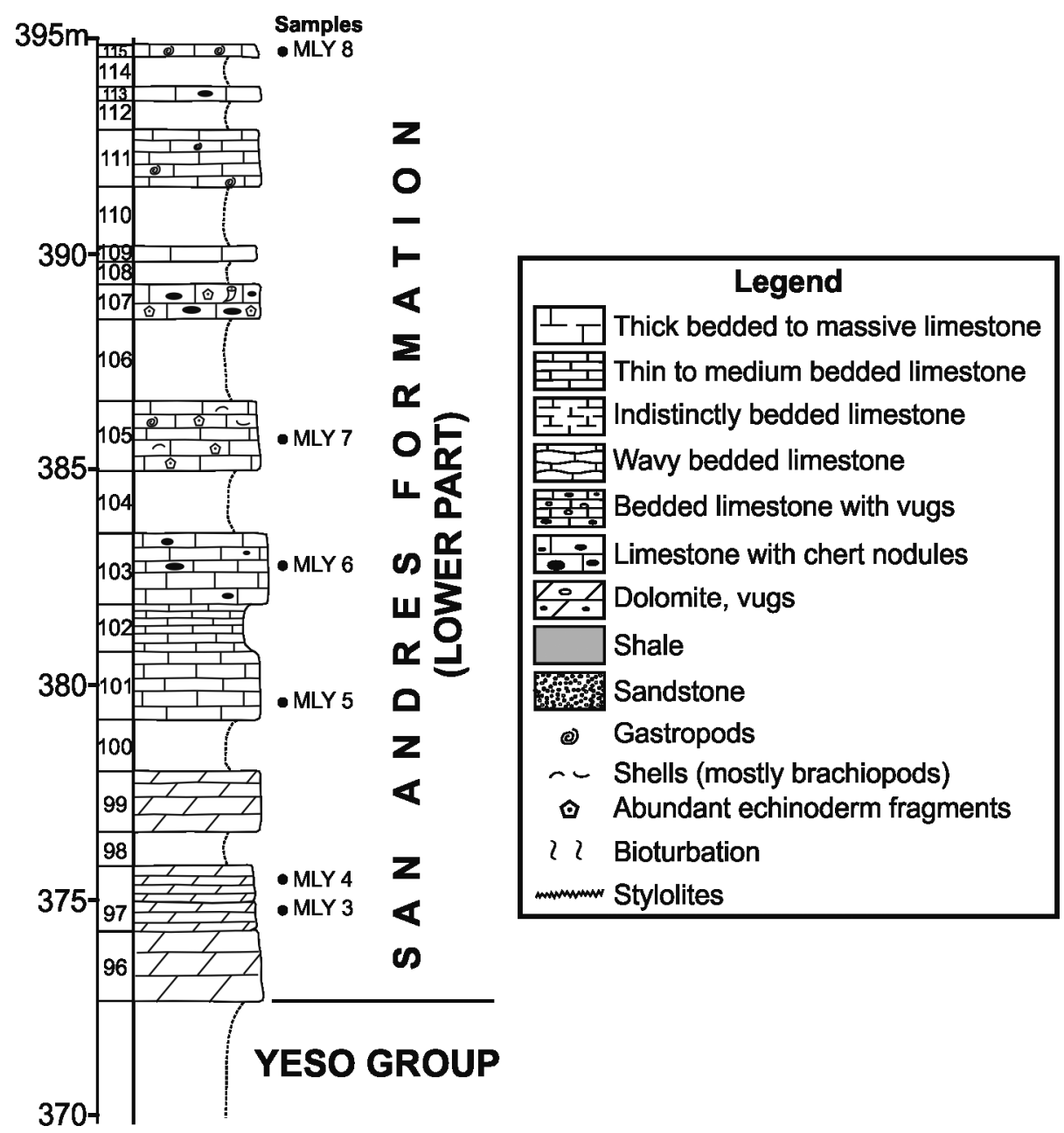

FIGURE 6. Detailed stratigraphic column of the lower part of San Andres Formation, in the McLeod Hills (southern Caballo Mountain), with thicknesses and sample MLY locations.

The succession rests on a very thin Glorieta Formation (= Glorieta Sandstone). The San Andres Formation section, which has an eroded top (and is probably incomplete), can be divided into lower, middle and upper parts (Krainer et al., 2012). The lower part (30 m thick) is composed of thick-bedded to massive, rare thin-bedded, gray to dark gray, bituminous, muddy limestone. The middle part (33 $\mathrm{m}$ thick) consists of thin- to thick-bedded limestone and massive limestone beds up to $4.3 \mathrm{~m}$ thick. Limestone is gray to dark gray and of muddy texture. The upper part is $67 \mathrm{~m}$ thick and composed of medium- to thick-bedded, partly indistinctly bedded, light to dark gray limestone, which rarely contain chert nodules. Richly bioclastic wackestone is the dominant microfacies, whereas subordinate microfacies are rudstone, floatstone and in the upper part grainstone (see details in Krainer et al., 2012). Smaller foraminifers and cal- careous algae are present throughout the section; particularly, in its top (samples SAR 8, 11, 13 and 20).

The succession, approximately $22 \mathrm{~m}$ thick, overlying the Yeso Group in the McLeod Hills, southern Caballo Mountains (Figure 6), has been assigned to the San Andres Formation by Lucas and Krainer (2012). It is composed of massive to bedded dolomite, and bedded (mostly 20-40 cm) dolomitic limestone and limestone. Individual pure limestone intervals are up to $1.6 \mathrm{~m}$ thick; they contain echinoderm fragments (mainly crinoids), bryozoans, brachiopods, gastropods and rare corals. A few limestone beds contain chert nodules and silicified fossils; they are composed of wackestone with a high diversity fossil assemblage (including algal wackestone) and bioclastic mudstone with a low diversity fossil assemblage (samples MLY 3-8; Figure 6). The wackestone indicates deposition in 


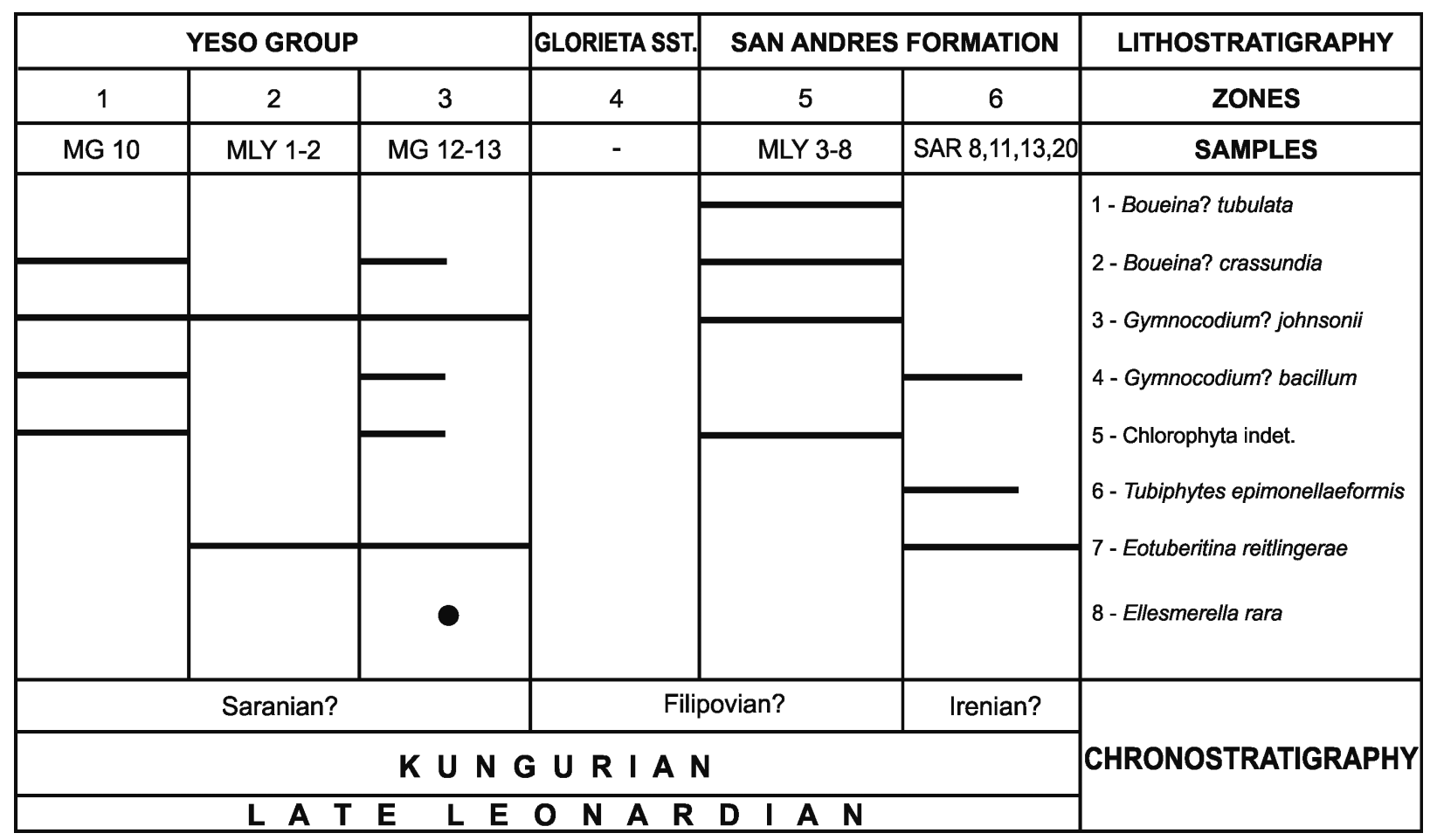

FIGURE 7. Distribution of the studied algae, and microproblematica, and their biozonation and proposed chronstratigraphy, in the Yeso Group and San Andres Formation (New Mexico, USA).

an open marine, shallow shelf environment of dominantly low to moderate water turbulence; whereas the mudstone, containing vugs filled with calcite pseudomorphs of gypsum or other evaporite minerals, and a less diverse fossil assemblage indicates deposition in a restricted environment with increased salinity (Krainer et al., 2012). Nautiloids and ammonoids indicate a late Leonardian age (Kottlowski et al., 1956).

\section{BIOSTRATIGRAPHIC SUBDIVISIONS}

Two parallel biostratigraphic scales for the Yeso Group and San Andres Formation, are presented in this paper (Figures 7, 8, 9). These biozones are proposed, following the definitions of Salvador (1994), in order to: 1) propose a first consistent biozonation of the different lithostratigraphical units; 2) try to correlate the lithological units across New Mexico; 3) permit correlations in North America and eventually with the type Kungurian in Russia.

The Yeso Group is subdivided into three zones of calcareous algae and microproblematica (Figure 7):
Zone 1 with Boueina? crassundia n. gen. n. sp. and Gymnocodium? johnsonii lowestoccurrence zone;

Zone 2 with Gymnocodium? johnsonii n. sp. interval zone;

Zone 3 with Ellesmerella rara n. sp. and Gymnocodium? johnsonii n. sp. assemblage zone.

The Glorieta Formation is barren of microfossils and corresponds to an informal fourth zone.

The San Andres Formation is subdivided into two zones (Figure 7):

Zone 5 with Boueina? tubulata n. sp. taxon-range zone;

Zone 6 with Tubiphytes epimonellaeformis n. sp. taxon-range zone;

Similarly, the Yeso Group and San Andres Formation are subdivided here into six zones of smaller foraminifers (Figures 8, 9), which are probably exactly in correlation with the six biozones of calcareous algae and microproblematica which have just been proposed:

Zone 1 with Glomomidiella infrapermica n. sp, and Orthovertellopsis protaeformis n. sp. lowest-occurrence zone;

Zone 2 with G. parapiciformis n. sp. and Nestellorella? sp. assemblage zone; 


\begin{tabular}{|c|c|c|c|c|c|c|}
\hline \multicolumn{3}{|c|}{ YESO GROUP } & GLORIETA SST. & \multicolumn{2}{|c|}{ SAN ANDRES FORMATION } & \multirow{2}{*}{$\begin{array}{c}\text { LITHOSTRATIGRAPHY } \\
\text { ZONES }\end{array}$} \\
\hline 1 & 2 & 3 & 4 & 5 & 6 & \\
\hline \multirow[t]{12}{*}{ MG 10} & MLY 1-2 & MG $12-13$ & - & MLY 3-8 & SAR $8,11,13,20$ & \multirow{12}{*}{\begin{tabular}{|l}
\multicolumn{1}{|c|}{ SAMPLES } \\
1 - Globivalvulina parapaciformis \\
2 - Globivalvulina retroseptata \\
3 - Globivalvulina novamexicana \\
4 - Globivalvulina praegraeca \\
5 - Orthovertellopsis proteaeformis \\
6 - Orthovertellopsis calcitornellaeformis \\
7 - Olgaorlovella davydovi \\
8 - Glomomidiella infrapermica \\
9 - Praeneodiscus convexus \\
10 - Ammovertella sp. \\
11 - Palaeonubecularia sp. \\
12 - Calcitornella elongata \\
13 - Hemigordiellina cf. elogans \\
14 - Hemigordiellina aff. elegans \\
15 - Hemigordiellina? cf. simplex
\end{tabular}} \\
\hline & & & & & & \\
\hline & & & & & & \\
\hline & & & & & & \\
\hline & & & & & & \\
\hline & & & & & & \\
\hline & & & & & & \\
\hline & & & & & & \\
\hline & & & & & & \\
\hline & & & & & & \\
\hline & & & & & & \\
\hline & & & & & & \\
\hline \multicolumn{3}{|c|}{ Saranian? } & \multicolumn{2}{|c|}{ Filipovian? } & Irenian? & \multirow{3}{*}{ CHRONOSTRATIGRAPHY } \\
\hline \multicolumn{6}{|c|}{$K \cup N G \cup R$ I $A N$} & \\
\hline & $\mathbf{L} \mathbf{A}$ & L E & O $N A$ A & D I A A & & \\
\hline
\end{tabular}

FIGURE 8. Distribution of the smaller foraminifers (taxa 1 to 15), and their biozonation and proposed chronstratigraphy, in the Yeso Group and San Andres Formation (New Mexico, USA).

Zone 3 with "Frondicularia" aff. turae taxon-range zone;

Zone 4 with the Glorieta Formation barren of microfossils;

Zone 5 with Praeneodiscus convexus n. gen. n. sp. and Orthovertellopsis calcitornellaeformis n. gen. n. sp. assemblage zone;

Zone 6 with Olgaorlovella davydovi n. gen. n. sp. taxon-range zone.

\section{FORAMINIFERAL AND CALCAREOUS ALGAL ASSEMBLAGES}

The regional Kungurian assemblages from the Yeso Group and San Andres Formation are composed of: 1) common codiacean and gymnocodiacean algae including species of Boueina?, Gymnocodium? and undetermined Chlorophyta (Figure 10, Figure 11, Figure 12, Figure 13, Figure 14 , Figure 15, Figure 16, Figure 17, Figure 18, Figure 19 , Figure 20 ); 2) relatively common smaller foraminifers including species of Globivalvulina,
Ammovertella, Calcitornella, Palaeonubecularia, Orthovertellopsis, Hemigordiellina, Pseudospira, Olgaorlovella, Hemigordius, Glomomidiella, Praeneodiscus, Protonodosaria?, Nodosinelloides, Nestellorella?, Geinitzina, "Frondicularia", and Gen. indet. (Figures 20, 21, 22, 23, 24, 25, 26, 27 , $28,29,30,31,32,33,34,35,36$ ); and 3) some microproblematica including species of Tubiphytes, Ellesmerella, and Eotuberitina (Figures 10, 11, 12, $13,14,19,22,24)$.

\section{ABBREVIATIONS AND REPOSITORY}

In the systematic part below, we used the following abbreviations for the algae: $L=$ length, $D=$ outer diameter, $d=$ inner diameter, $s=$ thickness of wall, $p=$ diameter of pores (= diameter of laterals), and ip = interval between two pores (i.e., between two laterals). For the foraminifers, the abbreviations are as follows: $L=$ length, $H=$ height, $D=$ outer diameter, $d=$ inner diameter, $s=$ wall thickness, $w=$ width, $w / D=$ ratio width to outer diameter, $p=$ proloculus diameter, $n=$ number of whorls, 


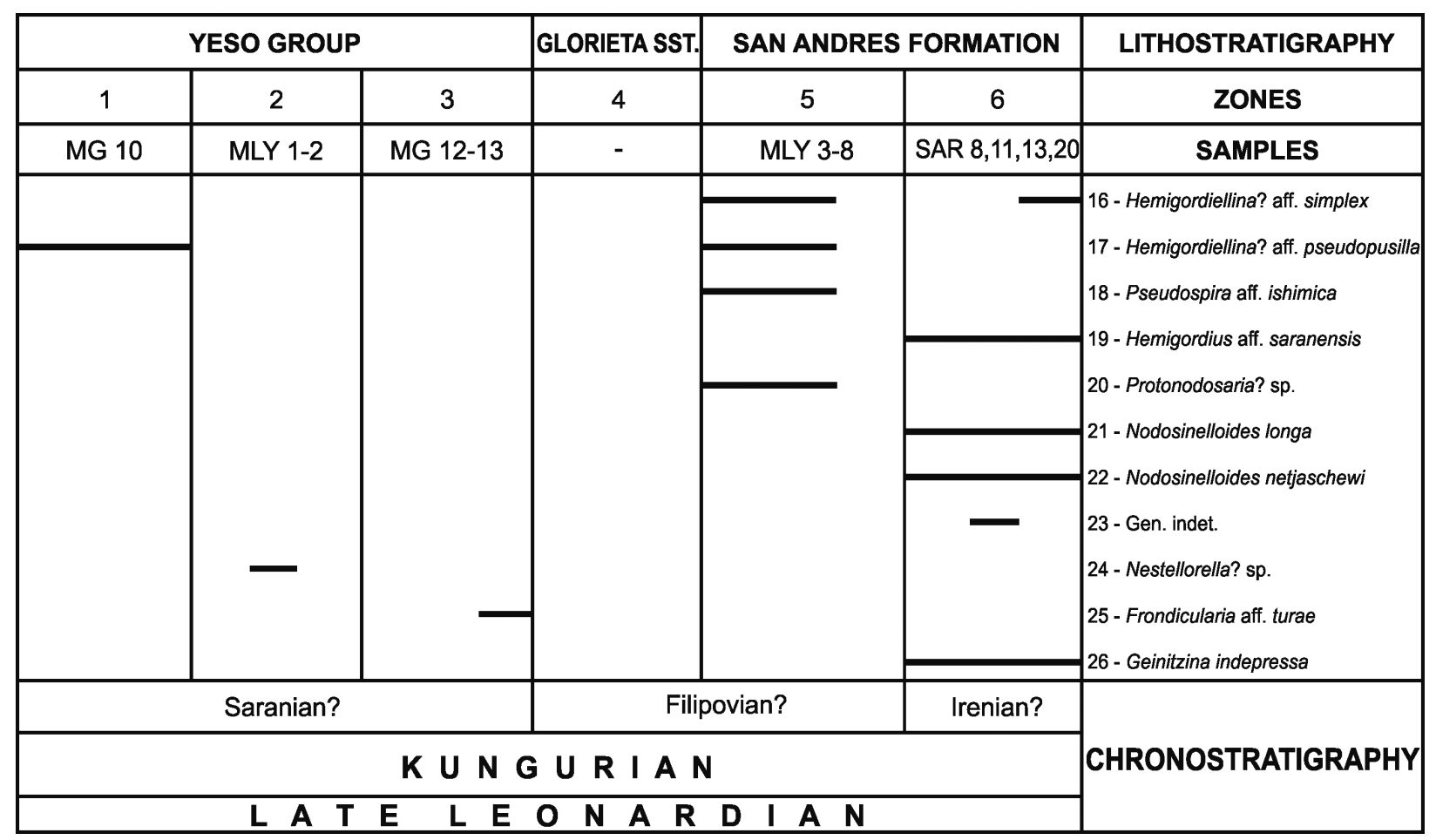

FIGURE 9. Distribution of the studied smaller foraminifers (taxa 16 to 26), and their biozonation and proposed chronstratigraphy, in the Yeso Group and San Andres Formation (New Mexico, USA).

and $\mathrm{h}=$ height of last whorl or height of last chamber.

All type specimens (holotypes and paratypes) of algae and foraminifers are housed in the collection of the New Mexico Museum of Natural History and Science and have NMMNH catalogue numbers.

\section{SYSTEMATIC PALAEONTOLOGY}

Phylum CHLOROPHYCOPHYTA Papenfuss, 1955 Class BRYOPSIDOPHYCEAE Bessey, 1907 Order BRYOPSIDALES Schaffner, 1922

Description. See e.g., Chuvashov, Luchinina, Shuysky, Shaikin, Berchenko, Ishchenko, Saltovskaya and Shirshova, 1987.

Remarks. The bryopsidales (codiales or caulerpales auctorum) appeared in the Ordovician and were abundant and diverse in back-reef environments during the Late Silurian and Early to Middle Devonian (Rothpletz, 1908; Poncet, 1982, 1990; Roux, 1985; Chuvashov et al., 1987; Mamet and Préat, 1994; Vachard, 1993). However, unquestionable bryopsidalean genera are very rare during Carboniferous and Permian times (e.g., Vachard et al., 1989b, 2001; Parvizi et al., 2013), whereas many Middle-Late Permian taxa belong to Gym- nocodiaceae or "phylloid algae", the botanical assignment of which is discussed. These questionable genera are Succodium Konishi, 1955; Aphroditicodium Elliott, 1970; Tauridium Güvenç, 1966; Tibeticodium Mu, 1982; Nanjinophycus $\mathrm{Mu}$ and Riding, 1983; and Thaiporella Endo, 1969, which, although described as codiaceans, instead belong to gymnocodiaceans. Pia (1937), Elliott (1955) and Kochansky-Devidé and Sliskovic (1969) interpreted the gymnocodiaceans as galaxauracean red algae, based on the shape and subcortical location of the conceptacles, and the intraskeletal tubular elements identified as long files of cells. More recently, the gymnocodiaceans have been transferred to the green algae (Mu and Riding, 1983; Chuvashov et al., 1987; Bucur, 1994; Radoicic, 2004; and Schlagintweit and Sanders, 2007). Morphologically, it is evident that the files of cells are rarely visible (except for Tauridium, perhaps) and that the deltoid terminations of many genera are similar to the utricles of the codiaceans.

Phylogenetically, the assignment to the galaxauraceans leads to many problems with a very problematical and puzzling history: 1) unquestionable pre-Middle Permian ancestors are unknown; the Devonian "Gymnocodium" devonicum Mamet et al., 1993, is most probably a fossil ulotrichale 

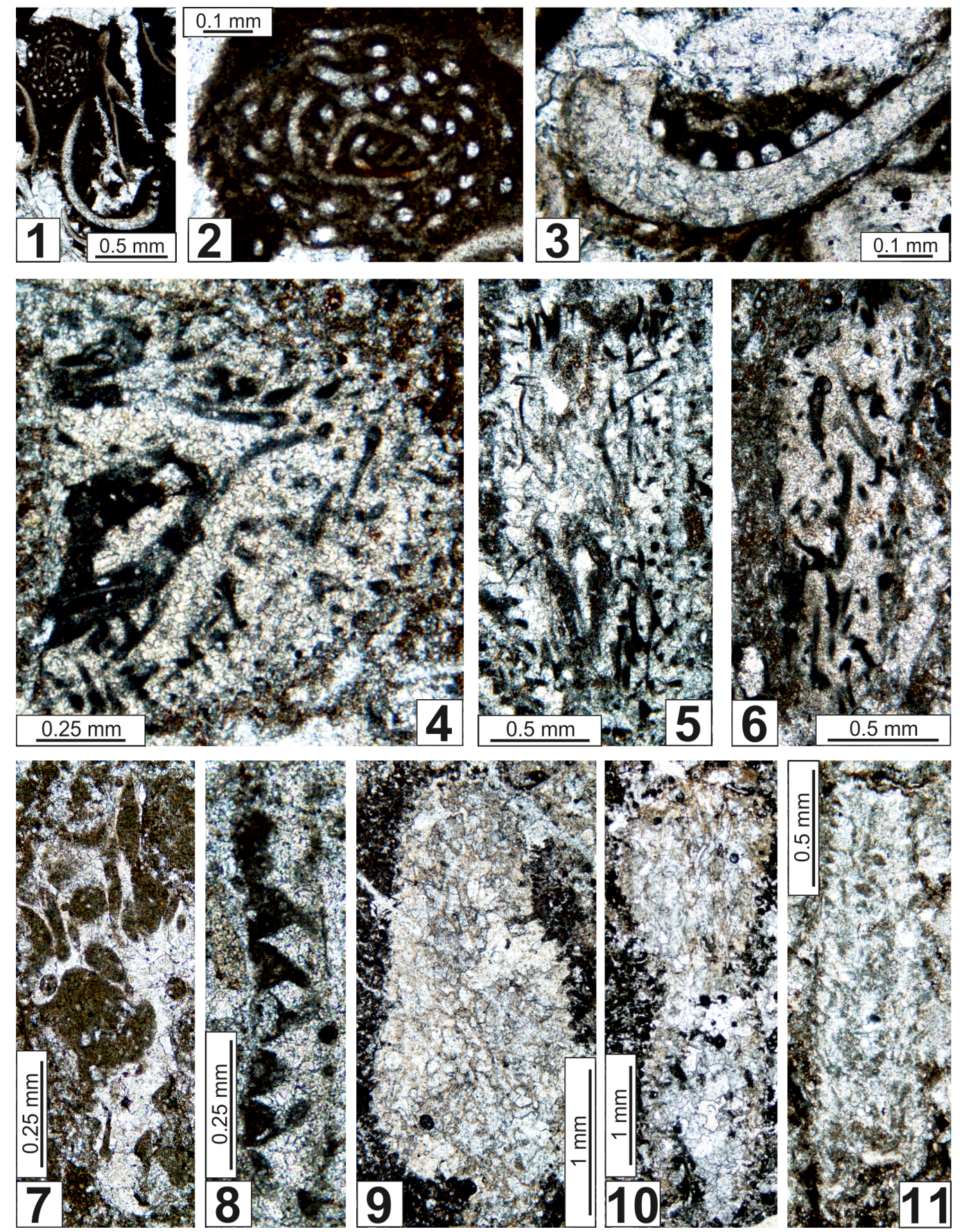

FIGURE 10. 1-3. Ellesmerella rara n. sp. 1. NMMNH P-67501, holotype and microfacies. Yeso Group. Sample MG 13c. 2. NMMNH P-67501, detail of holotype. Yeso Group. Sample MG 13d. 3. NMMNH P-67502, paratype encrusting the concavity of a bivalve shell. Yeso Group. Sample MG 13i. 4-6. Boueina? tubulata n. sp. 4. NMMNH P-67504, paratype. Oblique section with two medullar siphons (left) and numerous cortical siphons. San Andres Fm. Sample MLY(2) 5-17. 5. NMMNH P-67503, holotype. Axial section. San Andres Fm. Sample MLY(2) 6-12. 6. NMMNH P67505, paratype. Axial section. San Andres Fm. Sample MLY(2) 6-19b. 7-8. Undetermined Chlorophyta. 7. NMMNH P-67514, subaxial section with possible connections between two orders of siphons or of laterals L1 and L2 (top, right). Yeso Group. Sample MG(2) 12-1. 8. Oblique section with distal parts of siphons or laterals. San Andres Fm. Sample MLY(2) 6-9. 9-10. Gymnocodium? johnsonii n. sp. 9. NMMNH P-67509, holotype. Longitudinal section. Yeso Group. Sample MG(2) 12-4. 10. NMMNH P-67510, paratype. Compressed longitudinal section. Yeso Group. Sample MG(2) 12-12. 11. Gymnocodium? bacillum n. sp. NMMNH P-67513, holotype. Longitudinal section. San Andres Fm. Sample SAR 8a-4. 
(according to the criteria proposed by Kozlowski and Kazmierczak, 1968); 2) productivity was huge in Middle-Late Permian times followed by an almost total absence during the Triassic and the Early and Middle Jurassic; 3) a Lazarus effect occurs from Late Jurassic to Palaeocene; 4) a second Lazarus effect occurs in the Recent. Several derivations from one or several stocks of bryopsidales are most easy to imagine.

We speculate here that the phylogeny codiaceans-gymnocodiaceans really exists, and that our late Early Permian material has been particularly interesting for confirming this relationship with possible transitional forms similar to and/or ancestral to Boueina? described from our material.

Similarly, the "phylloid algae" are questionable codiacean algae. According to Schlagintweit (2010) and Granier (2012), the phylloid algae sensu lato can be considered as an informal botanical group. Indeed, the group defined by Pray and Wray (1963) is heterogenous, since it encompassed codiaceans (see Roux, 1985; Mamet et al., 1987; Forsythe et al., 2002; Torres, 2003), ancestral corallinales (see Wray, 1971; Vachard et al., 1989a; Corrochano et al., 2013), and algospongia (see Vachard et al., 1989a, 1989b, 2001, 2012; Vachard and Cózar 2010; Granier 2012; Parvizi et al., 2013). Furthermore, some representatives are probably the result of complex taphonomic interactions on algal thalli (Vachard et al., 1989a, 1989b, 2001). According to our published and unpublished data, the phylloid algae are to interpret as follows: 1) Eugonophyllum Konishi and Wray, 1961; Ivanovia Khvorova, 1946; Anchicodium Johnson, 1946; Neoanchicodium Endo in Endo and Kanuma, 1954; Kansaphyllum Baars, 1992; Calcipatera Torres, West and Sawin, 1992; and Iranicodium Senowbari-Daryan and Rashidi, 2010 most probably belong to the codiaceans (moreover, there are many generic synonymies; see discussion in Parvizi et al. (2013)); 2) Archaeolithophyllum Johnson, 1956 is typically a red alga; and perhaps, the unique unquestionable Palaeozoic calcareous red alga (Vachard et al., 1989a, 2001; Kirkland et al., 1991, 1993; Dawson, 1992; Moshier and Kirkland, 1993; Pintigore, 1994; Corrochano et al., 2013); 3) Calcifolium Maslov, 1956 and the calcifoliids differ totally and belong to the incertae sedis algosponges (Vachard and Cózar, 2010).

Occurrence. Ordovician to Recent; cosmopolitan in subtropical seas.

Family CODIACEAE Kützing, 1843

Synonyms. Dimorphosiphonaceae (Shuysky in Chuvashov, Luchinina, Shuysky, Shaikin, Berch- enko, Ishchenko, Saltovskaya and Shirshova, 1987) Vachard, 1993; Codiaceae Kützing, 1843 (partim); Praecodiaceae Dragastan, 2008 (partim); Scribroporellaceae (Rietschel, 1966) Vachard, 1993 emend. Vachard, Haig and Mory, 2014 (partim).

Description. Large thalli not segmented, probably cylindrical or club-shaped. Broad medullar zone poorly preserved. Subcortical zone with subvertical siphons, acrophore, slightly phloiophore or perhaps vesiculifer, more or less euspondyl. Cortical zone with fine siphons linked in tuft-like groups and showing several ramifications with constant diameter up to the outer surface, and terminated by circular pores (deltoid terminations corresponding to utricles are inconspicuous). Reproductive structures unknown (the occasionally mentioned subcortical conceptacles are in fact misinterpreted and correspond to lithophagous perforations). Wall whitish, microsparitized, probably originally aragonitic.

Composition. Six Palaeozoic tribes (plus eventually two tribes of "phylloid algae" to emend): Ivanoviae Shuysky in Chuvashov et al. (1987) and Paradelleae Maslov, 1956: Lanciculeae Shuysky, 1985; Palaeoporelleae Shuysky in Chuvashov et al. (1987); Abacelleae Shuysky in Chuvashov et al. (1987); Ampulliporeae Shuysky in Chuvashov et al. (1987); Botryelleae Shuysky in Chuvashov et al. (1987); and the first Boueineae Shuysky in Chuvashov et al. (1987) (orth. mut.; sic: Boueneae).

Remarks. The name Codiaceae has priority over Scribroporellaceae as well as Dimorphosiphonaceae and encompasses the majority of the Praecodiaceae. The Palaeozoic members of this family constitute a group that shares morphological and possible phylogenetic affinities with various fossil ulotrichales (Kozlowski and Kazmierczak, 1968), gymnocodiales, dasycladales, and siphonales.

Occurrence. Ordovician-Holocene; widespread on Palaeotethys and Urals Ocean shelves during the Late Palaeozoic.

Tribe BOUEINEAE Shuysky in Chuvashov, Luchinina, Shuysky, Shaikin, Berchenko, Ishchenko, Saltovskaya and Shirshova, 1987

Description. Codiaceae with a medullar zone well to poorly preserved. Cylindrical thalli (or segments). Medullar zone with coarse, tangled siphons. Subcortical zone with subvertical siphons, acrophore to slightly phloiophore, more or less euspondyl. Cortical zone with perpendicular, thin, acrophore, finer, ramified siphons first parallel and then linked in tuft-like groups and showing several 

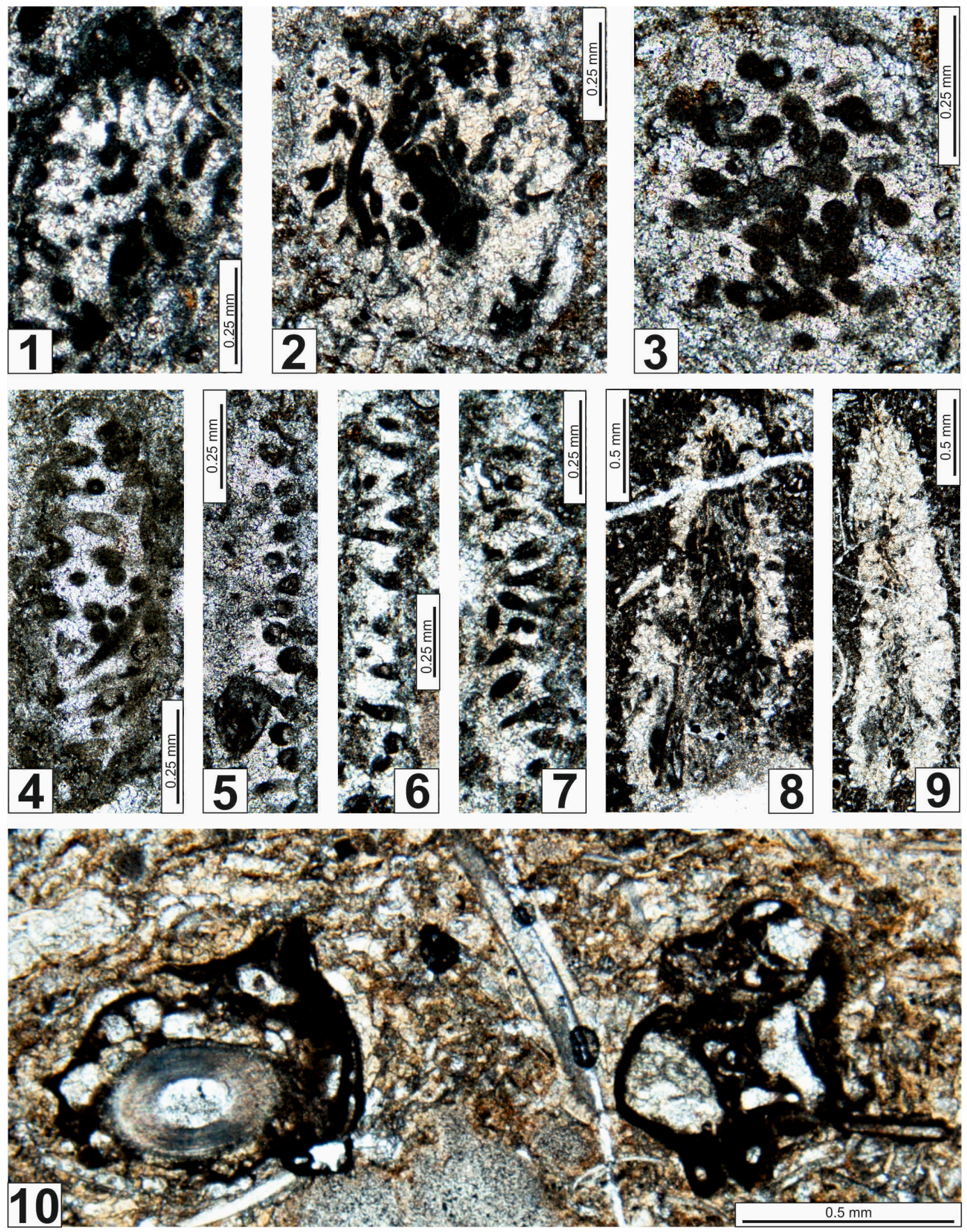

FIGURE 11. 1-4, 6-7. Boueina? crassundia n. sp. 1. NMMNH P-67506, holotype. Oblique section showing all the types of siphons. San Andres Fm. Sample MLY(2) 6-7a. 2. NMMNH P-67494, paratype. Axial section. San Andres Fm. Sample MLY(2) 5a-13. 3. NMMNH P-67495, paratype. Axial section with medullar siphons. San Andres Fm. Sample MLY(2) 5a-11. 4. NMMNH P-67507, paratype. Oblique section with cortical siphons. San Andres Fm. Sample MLY(2) 6-27. 6. NMMNH P-67507, paratype. Oblique sections with cortical siphons (already illustrated in Brose et al., 2013, figure 6.8). San Andres Fm. Sample MLY(2) 5-9. 7. NMMNH P-67496, paratype. Oblique section with cortical siphons. San Andres Fm. Sample MLY(2) 6-28. 5. Undetermined Chlorophyta. NMMNH P-67516, oblique sections with siphons or L2 and L1 laterals (bottom, left). San Andres Fm. Sample MLY(2) 6-10. 8-9. Gymnocodium? johnsonii n. sp. 8. NMMNH P-67511, paratype. Axial section with well preserved medullar zone. Yeso Group. Sample MG(2) 12-3. 9. NMMNH P-67512, paratype. Axial section more recrystallized than Figure 11.8. Specimen already illustrated in Lucas et al. (2013b, figure 8J). Yeso Group. Sample MG(2) 12-5. 10. Tubiphytes epimonellaeformis n. sp. NMMNH P-67518, a paratype encrusting a productoid spine (left); another paratype (right); and an isolated brachiopod spine (centre). San Andres Fm. Sample SAR 12-3. 
ramifications with constant diameter up to the outer surface.

Composition. Boueina Toula, 1884; Boueina? (this study); Maslovina Obrhel, 1968; Pseudolitanaia Mamet and Préat, 1994; Bijagodella Chuvashov, Yuferev and Liuchinina, 1985; Poncetellina Mamet and Roux, 1984; Palaeoporella? sp. sensu Vachard, 1988; Funiculus Shuysky and Shirshova in Chuvashov et al. (1987); Arabicodium Elliott, 1957.

Remarks. Boueinae? differs from the other tribes of Palaeozoic Codiaceae listed above, and especially from Litanaiae Shuysky in Chuvashov et al. (1987), by the weak development or absence of inflated parts in the siphons and/or deltoid terminations (utricles). Some Devonian taxa have more affinities with Boueineae than Litanaiae or Palaeoporelleae Shuysky in Chuvashov et al. (1987), such as Maslovina meyenii Obrhel, 1968; M. australensis Mamet and Pohler, 2002; Pseudolitanaia graecensis [sic; to correct in graeca] (Hubmann, 1990) Mamet and Préat, 1994; Paralitanaia baileuxensis Mamet and Préat, 1985; Praelitanaia anirica (Maslov, 1956) Shuysky in Chuvashov et al. (1987); Bijagodella bijagodensis (Chuvashov, 1973) Chuvashov et al. (1985); etc. (the diagnoses of these taxa are compiled, for example, in Bassoullet et al. (1983)). Arabicodium seems to be morphologically transitional between Boueina and Halimeda Lamouroux, 1812 (see Elliott, 1982; Bassoullet et al., 1983).

Occurrence. FAD in the Late Silurian with Maslovina. First acme in the Middle Devonian with Funiculus. The tribe is present with Palaeoporella? $\mathrm{sp}$. at the Devonian-Carboniferous boundary (Vachard, 1988, plate 1, figure 7). Boueina is known from the Late Triassic of Thailand (Flügel, 1988) to Early Cretaceous (Toula, 1884). LAD in early Eocene with Arabicodium (Bassoullet et al., 1983).

\section{Genus BOUEINA?}

Description. Cylindrical Boueineae with medium, tangled, longitudinal medullary threads with long segments of tubes; and fine, oblique, and one time branching, radial or oblique cortical threads. The subdermal zone shows fine terminal branchlets (and very rarely very small deltoid terminations). No reproductive organs obvious.

Composition. Boueina? tubulata n. sp.; B.? crassundia n. sp.; Boueina sp. sensu Maslov (1973, plate 12, figure 4).

Remarks. Boueina? differs from true Boueina by having less ramification orders in the cortical zone, less difference in filament diameters between the cortical and medullar zones, and shorter and more rectilinear medullar siphons (see Elliott, 1970, table 2). These differences are presently insufficient to permit the description of a new genus. The coeval genus Nanjinophycus Mu and Riding, 1983 (from the late Bolorian = latest Kungurian = Misellina claudiae Deprat fusulinid zone of the Nanjing area in China), differs fundamentally by the cortex of typically gymnocodiacean deltoid terminations. Moreover, incomplete and/or abraded fragments may be relatively identical, due to relatively similar cortical and medullar siphons.

Occurrence. Kungurian (late Leonardian) of New Mexico. Middle Permian of Armenia (Maslov, 1973).

Boueina? tubulata n. sp.

Figures 10.4-10.6, 13.3, 13.6, 13.7, 18.1-18.5

zoobank.org/07418D5F-E7B7-4290-A6BF-D446556580E8

v. 2013b Boueina? sp. 1; Vachard, Krainer and Lucas, p. 348 (no illustration).

Etymology. Latin tubulatus: bearing small tubes.

Holotype. NMMNH P-67503; Figure 10.5; sample MLY(2) 6-12.

Paratypes. NMMNH P-67504, 67505; Figure 10.4, 10.6.

Material. 52 specimens.

Locus Typicus. NMMNH locality 8892, San Andres Formation, McLeod Hills (New Mexico).

Stratum Typicum. Middle? Kungurian (late Leonardian).

Diagnosis. Boueina? with thin siphons in both medullar and cortical zones.

Description. The thallus is cylindrical and measures: $L=0.86-1.86 \mathrm{~mm}$ and $\mathrm{w}=$ (rarely $0.34-0.47$ ) $0.72-1.25 \mathrm{~mm}$. Medullar zone with medium-sized, tangled, longitudinal threads exhibiting long segments of tubes with a diameter of (rarely $0.01 \mathrm{~mm}$ ) 0.02-0.04 $\mathrm{mm}$. Cortical zone with fine $(0.01 \mathrm{~mm})$, oblique, and one time branching, radial or oblique threads. The subdermal zone shows some small deltoid terminations, $0.03 \mathrm{~mm}$ wide.

Occurrence. Middle? Kungurian (late Leonardian) of New Mexico (San Andres Formation, McLeod Hills (lower part): samples MLY 5-8, MLY 5-10, MLY 5-14, MLY(2) 5-17, MLY(2) 5-19, MLY(2) 5a-2, MLY(2) 5a-9, MLY(2) 5a-20, MLY(2) 5a-26, MLY(2) 6-4, MLY(2) 6-8, MLY(2) 6-12, MLY(2) 6-19a, $\operatorname{MLY}(2)$ 6-19b, MLY 6-20)).

Boueina? crassundia n. sp.

Figures 11.1-11.4, 11.6, 11.7, 13.1, 13.2, 13.4, $13.5,13.8,13.10,14.1-14.4,14.10,15.1,15.2$, 

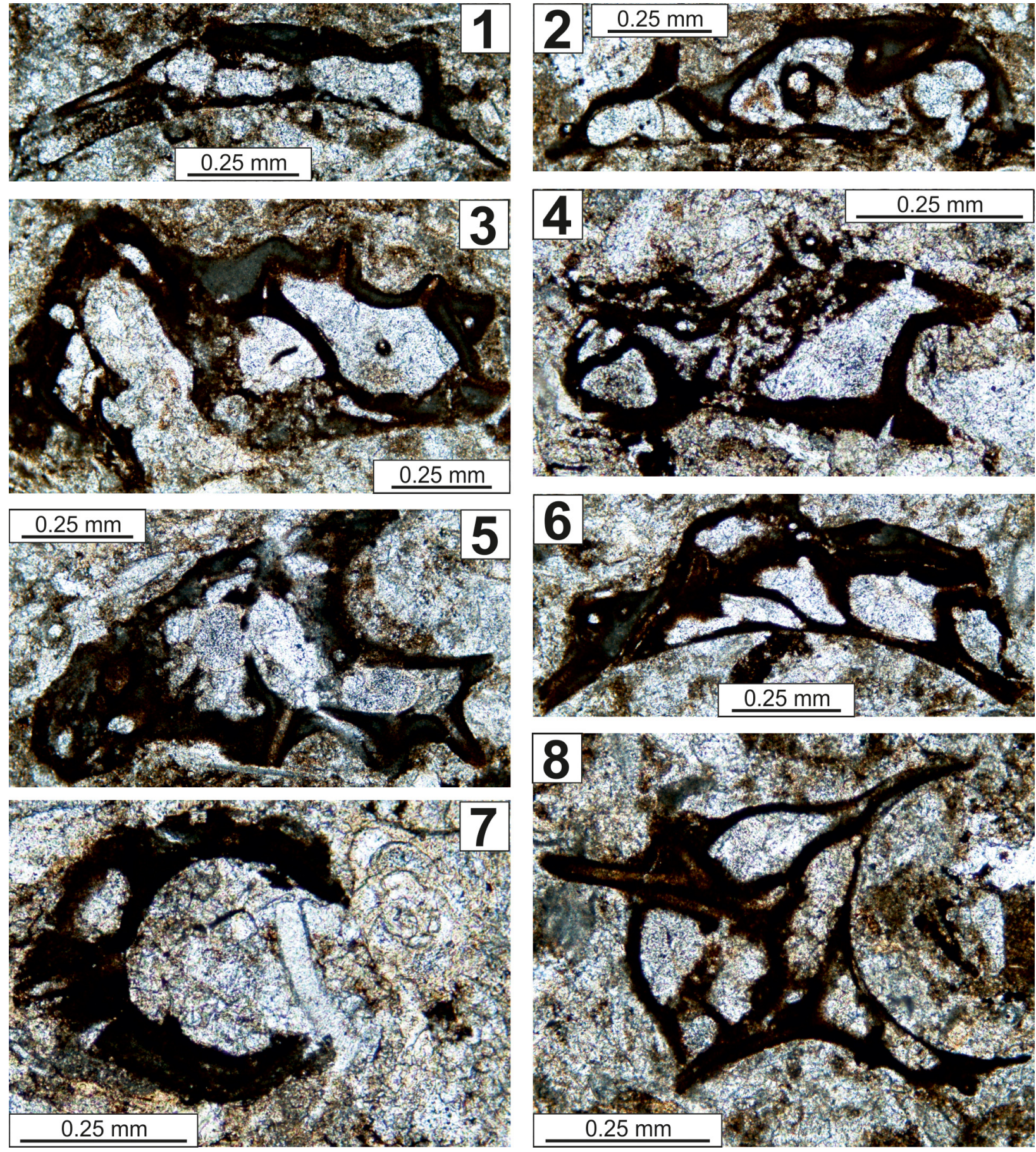

FIGURE 12. 1-8. Tubiphytes epimonellaeformis n. sp. 1. NMMNH P-67517, holotype. San Andres Fm. Sample SAR(2) 12-2. 2. NMMNH P-67518, paratype. San Andres Fm. Sample SAR(2) 12-3a. 3. NMMNH P-67519, paratype. San Andres Fm. Sample SAR(2) 12-3. 4. NMMNH P-67520, paratype. San Andres Fm. Sample SAR(2) 11-9. 5. NMMNH P-67521, paratype. San Andres Fm. Sample SAR(2) 12-12. 6. NMMNH P-67522, paratype. San Andres Fm. Sample SAR(2) 12-8. 7. NMMNH P-67523, paratype with Olgaorlovella davydovi n. gen. n. sp. (paratype; top right). San Andres Fm. Sample SAR(2) 11-8. 8. NMMNH P-67524, paratype. San Andres Fm. Sample SAR(2) 12-13. 
$15.4,15.7,15.9,16.1,16.2,16.6,16.8,18.6-18.11$, $20.13,20.15$

zoobank.org/F99005B2-1230-43E7-992C-18910EB11B9A

v. 2013 Paraboueina; Brose, Lucas and Krainer, fig. 6.8 .

v. 2013b Boueina? sp. 2; Vachard, Krainer and Lucas, p. 348 (no illustration).

Etymology. Latin crassundia: large intestine; because of the broad medullar siphons.

Holotype. NMMNH P-67506; Figure 11.1; sample MLY(2) 6-7a.

Paratypes. NMMNH P-67494, 67495, 67496, 67507, 67508; Figure 11.2-4, 11.6-7.

Material. 200 specimens.

Locus Typicus. NMMNH locality 8892; San Andres Formation, McLeod Hills (New Mexico).

Stratum Typicum. Middle? Kungurian (late Leonardian).

Diagnosis. Boueina? with broad siphons in both medullar and cortical zones.

Description. The thallus is cylindrical $(L=1.00-$ $1.75 \mathrm{~mm} ; \mathrm{w}=0.45-0.75 \mathrm{~mm}$ ). Medullar zone with medium-sized, tangled, longitudinal threads exhibiting long segments of tubes with a diameter of $0.05-0.09 \mathrm{~mm}$. Cortical zone with relatively wide (0.03-0.04 mm), oblique, and one time branching, radial or oblique threads. The subdermal zone shows some small deltoid terminations (0.03-0.05 $\mathrm{mm}$ ).

Comparison. Boueina? crassundia n. sp. differs from B.? tubulata n. sp. by broader siphons, even where the other dimensions are the same. This character is not diagenetic because there are no transitional measurements.

Occurrence. Early?-middle? Kungurian (late Leonardian) of New Mexico (Yeso Group, Los Vallos Formation, Torres Member: samples MG 10-1, MG 10-10, MG(2) 12-6, MG(2) 12-11, MG(2) 1215; San Andres Formation, McLeod Hills (lower part); samples MLY 5-1, MLY 5-2, MLY 5-6, MLY(2) 5-6, MLY 5-7b, MLY(2) 5-9, MLY(2) 5-11, MLY(2) 514, MLY(2) 5-16, MLY 5-18, MLY(2) 5-18, MLY(2) 5-19, MLY(2) 5-19d, MLY 5-20, MLY 5-26, MLY 527, MLY 5-28, MLY(2) 5a-1, MLY(2) 5a-3, MLY(2) 5a-4, MLY(2) 5a-10, MLY(2) 5a-11, MLY(2) 5a-12, $\operatorname{MLY}(2)$ 5a-13, MLY(2) 5a-19, MLY(2) 5a-19a, MLY(2) 5a-21, MLY(2) 5a-23, MLY(2) 5a-25, $\operatorname{MLY}(2)$ 6-7, MLY(2) 6-7a, MLY 6-8, MLY(2) 6-8, MLY(2) 6-8a, MLY 6-10, MLY(2) 6-11, MLY 6-13, MLY 6-14, MLY(2) 6-15, MLY(2) 6-16, MLY(2) 6-17, $\operatorname{MLY}(2)$ 6-21, MLY(2) 6-27, MLY(2) 6-28, MLY(2) 630, MLY 8-3)).
Incerti ordinis

Family GYMNOCODIACEAE Elliott, 1955

Genus GYMNOCODIUM Pia, 1920 emend. Elliott, 1955

Type Species. Gyroporella bellerophontis Rothpletz, 1894.

Description. Gymnocodiaceae characterised by thallus rarely hollow and/or bifurcated; elongate cone shaped to pinching and swelling, circular in cross section. Medullar siphons oblique, numerous, preserved in the form of short segments; cortical siphons not ramified and with relatively wide deltoid terminations.

Occurrence. FAD poorly known; LAD at the Permian-Triassic Boundary. Common and cosmopolitan in the Late Permian (Carnic Alps, Southern Alps, Croatia, Montenegro, Serbia, Hungary, Greece, Tunisia, Turkey, Armenia, North Caucasus, Iran, Iraq, Saudi Arabia, Oman, Afghanistan, Pakistan, Ladakh, Tibet, South China, Thailand, Malaysia, Laos, Cambodia, Viet Nam, Japan, New Zealand, New Mexico, Guatemala).

\section{Genus GYMNOCODIUM?}

Description. The regional representatives differ from true Gymnocodium by the absence of conceptacles, the thallus less regularly cylindrical and not bifurcated, the occasionally well preserved medullary zone, the smaller deltoids, and the cortical siphons better preserved; however, these characters seem to be insufficient to create a distinct genus or subgenus. Gymnocodium? differs also from Permocalculus Elliott, 1955 in the thallus less regularly segmented, the wider deltoids, the lesser number of ramifications of the cortical siphons, and the absence of conceptacles.

Composition. Gymnocodium? johnsonii n. sp., $\mathrm{G}$ ? bacillum $\mathrm{n}$. sp. (and their possible synonyms indicated below).

Occurrence. Kungurian (= late Leonardian) of New Mexico; Artinskian-Kungurian (early-late Leonardian) of Guatemala. Possibly present in the Early Permian of South China ( $\mathrm{Li}$ and Mamet, 1993) and North China (Mamet and Zhu, 2005).

Gymnocodium? johnsonii n. sp. Figures 10.9, 10.10, 11.8, 11.9, 14.6, 14.7, 14.11, $15.3,15.5,15.6-15.8,15.10,15.11,16.3-16.5$, $16.7,16.9,17.5,17.8,17.9,18.11,19.1,19.2$, $19.4-19.6,19.9,20.17,20.19$

zoobank.org/BCE369DB-86A5-45C7-8EAA-073A16E94617

? 1965 Gymnocodium bellerophontis (Rothpletz); Johnson and Kaska, p. 64, pl. 1, figs. 1, 2, 3,4 . 

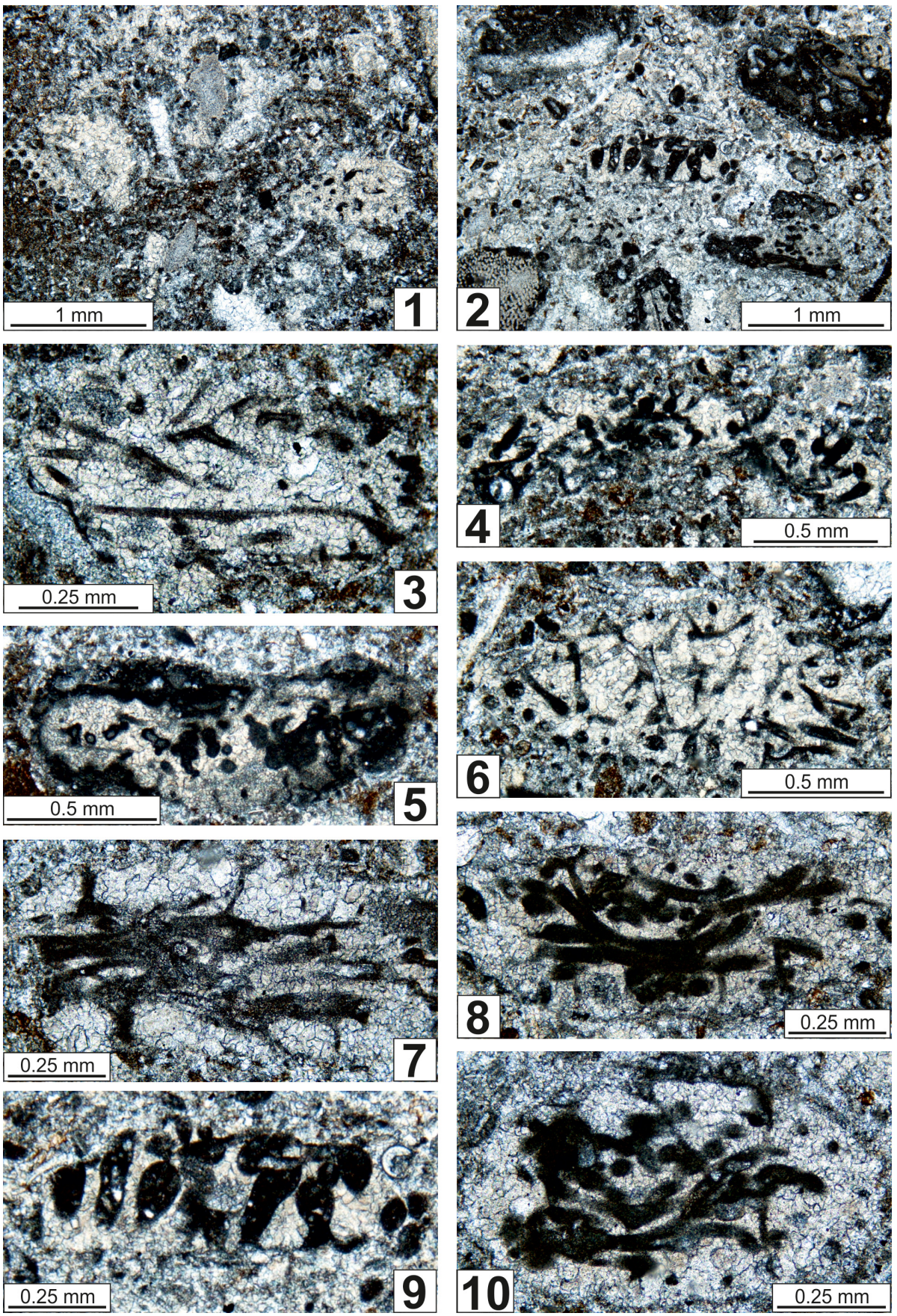

FIGURE 13. 1, 4-5, 8, 10. Boueina? crassundia n. sp. 1. Tangential section (right) with Gymnocodium? johnsonii $\mathrm{n}$. sp. (left) and crinoids (centre top and bottom). San Andres Fm. Sample MLY 5-26. 4. Oblique subaxial section showing the siphons of the medullar zone. San Andres Fm. Sample MLY 5-6. 5. Oblique section showing the siphons of the medullar zone. San Andres Fm. Sample MLY 5-18. 8. Axial section with cortical and medullar zones. San Andres Fm. Sample MLY 5-8. 10. Axial section with a well-developed medullar zone but a poorly preserved cortical zone. San Andres Fm. Sample MLY 5-20. 2, 9. Undetermined Chlorophyta. 2. Fragment of a longitudinal section and microfacies (bivalve, top left; Palaeonubecularia sp. (top right); Eotuberitina reitlingerae Miklukho-Maklay, 1958 (right, centre); crinoid (bottom left); Boueina? crassundia n. sp. (bottom right)). San Andres Fm. Sample MLY 5-2. 9. Detail of Figure 13.2; with Eotuberitina reitlingerae Miklukho-Maklay, 1958 (top right). San Andres Fm. Sample MLY 5-2a. 3, 6-7. Boueina? tubulata n. sp. 3. Subaxial section showing the ramified siphons of the medullar zone. San Andres Fm. Sample MLY 5-14. 6. Oblique subaxial section showing some ramifications of the siphons of the medullar zone. San Andres Fm. Sample MLY 5-7b. 7. Axial section with typical cortical and medullar siphons. San Andres Fm. Sample MLY 5-10. 
? 1965 Permocalculus cf. tenellus Pia; Johnson and Kaska, p. 64-65, pl. 2, fig. 1.

? 1993 Gymnocodium; Li and Mamet, fig. 4F.

? 2005 Gymnocodium; Mamet and Zhu, fig. 6H.

v. 2013b Gymnocodium; Lucas, Krainer and Voigt, fig. $8 \mathrm{H}, \mathrm{J}$.

v. 2013 Gymnocodiacean algae; Brose, Lucas and Krainer, fig. 6.1, 6.3.

v. 2013 Gymnocodium; Brose, Lucas and Krainer, fig. 6.9.

v. $2013 \mathrm{~b}$ Gymnocodium sp. 1; Vachard, Krainer and Lucas, p. 348 (no illustration).

Etymology. In memory of J.H. Johnson for his fundamental work on the North American algae.

Holotype. NMMNH P-67509; Figure 10.9; sample MG(2) 12-12.

Paratypes. NMMNH P-67510, 67511, 67512; Figures 10.10, 11.8-9.

Material. 275 specimens.

Locus Typicus. NMMNH locality 8893; Yeso Group, Los Vallos Formation, Torres Member, Massacre Gap in the southern Fra Cristobal Mountains (New Mexico).

Stratum Typicum. Early? Kungurian (late Leonardian).

Diagnosis. A Gymnocodium? characterised by some constrictions of the thallus, a poorly individualized medullar zone, and curved cortical siphons with large deltoid terminations.

Description. Thallus moderately large $(L=1.13$ $4.50 \mathrm{~mm}, \mathrm{w}=0.45-3.00 \mathrm{~mm}$ ), and periodically but asymmetrically compressed. Medullar zone generally sparitized and poorly individualized from the cortical zone. This cortical zone is relatively wide and crossed by euspondyl, curved, thin siphons, with terminal deltoids equilaterally triangular and relatively wide $(0.05-0.07(0.09) \mathrm{mm})$. Conceptacles not observed.

Comparisons. Gymnocodium? johnsonii n. sp. differs from the typical Gymnocodium by the characters indicated above. From the rare moniliform Gymnocodium as such as G. nodosum (OgilvieGordon, 1927) Bilgütay, 1959, it differs by larger dimensions $(\mathrm{w}=1.27-2.40 \mathrm{~mm}$ in this latter species; see Roux, 1991), irregular swelling (against regular barrel-like segments), and less deep deltoid terminations. It differs from Siamporidium elongatum Endo, 1969 by a less elongate test and less ramified cortical siphons.

The new taxon Gymnocodium? johnsonii n. sp., as one of the oldest representatives of the Gymnocodiaceae, may represent a missing link between an ancestral Boueina-like codiacean or
Nanjinophycus-like gymnocodiaceans and the true gymnocodiaceans; i.e., Gymnocodium and Permocalculus. Nevertheless, Permocalculus Elliott, 1955 might correspond to another branch of this lineage, because its FAD is possibly located as early as the Sakmarian (see, Homann, 1972, plate 1, figure 8; identified as Gymnocodium cf. gracile Kordé) or the early Wolfcampian (Buitrón-Sanchez et al., 2012); i.e., prior to the first occurrence of Gymnocodium? johnsonii n. sp.

Occurrence. Kungurian (late Leonardian) of New Mexico (Yeso Group, Torres Member: samples MG 10-13, MG(2) 10-15, MG(2) 12-3, MG(2) 12-4, MG 12-4a, MG(2) 12-5, MG(2) 12-8, MG 12-9, MG(2) 12-12, MG(2) 12-13, MG(2) 12-14, MG 13e; San Andres Formation, McLeod Hills, lower part (MLY) and reference sections (SAR): samples MLY 5-26, MLY(2) 5a-12, MLY(2) 5-13, MLY(2) 6-5, MLY 6-6, MLY(2) 6-6, MLY 6-7, MLY 6-11, MLY 6-12, MLY(2) 6-14, MLY(2) 6-15, MLY(2) 6-17, MLY(2) 6-18, MLY(2) 6-19, MLY(2) 6-20, MLY(2) 6-22, MLY 6-25, MLY 6-27, MLY 6-32, MLY 8-5, SAR 2-1, SAR 2-2, SAR 2-3, SAR 2-4, SAR 7-8, SAR 7-9, SAR(2) 8-7/ 8-17, SAR(2) 8-11, SAR 8-15, SAR 8a-15, SAR 8a16, SAR 8a-25)). Possibly present in the Artinskian-Kungurian (Leonardian) of Guatemala and in the Lower Permian of South China ( $\mathrm{Li}$ and Mamet, 1993) and North China (Mamet and Zhu, 2005).

Gymnocodium? bacillum n. sp.

Figures 10.11, 14.5, 14.8, 14.9, 19.3, 19.7, 19.8, $19.10-19.16,20.16$

zoobank.org/D6410A47-1864-4B04-BD65-1367AFF88A0F

v. 1997 Gymnocodium bellerophontis (Rothpletz); Vachard et al., figs. 12.2-9.

v. 2013b Gymnocodium sp. 2; Vachard, Krainer and Lucas, p. 348 (no illustration).

v. 2013b Dasycladacean algae; Lucas, Krainer and Voigt, fig. 8D.

Etymology. Latin bacillus, small stick.

Holotype. NMMNH P-67513; Figure 10.11; sample SAR 8a-4.

Material. 42 sections.

Locus Typicus. NMMNH locality 8894; San Andres Formation, reference section near Rhodes Canyon in the San Andres Mountains (New Mexico).

Stratum Typicum. Late? Kungurian (latest Leonardian).

Diagnosis. A Gymnocodium? characterised by small, stick-shaped segments, relatively well-preserved medullar zone, and moderately wide deltoid terminations. 

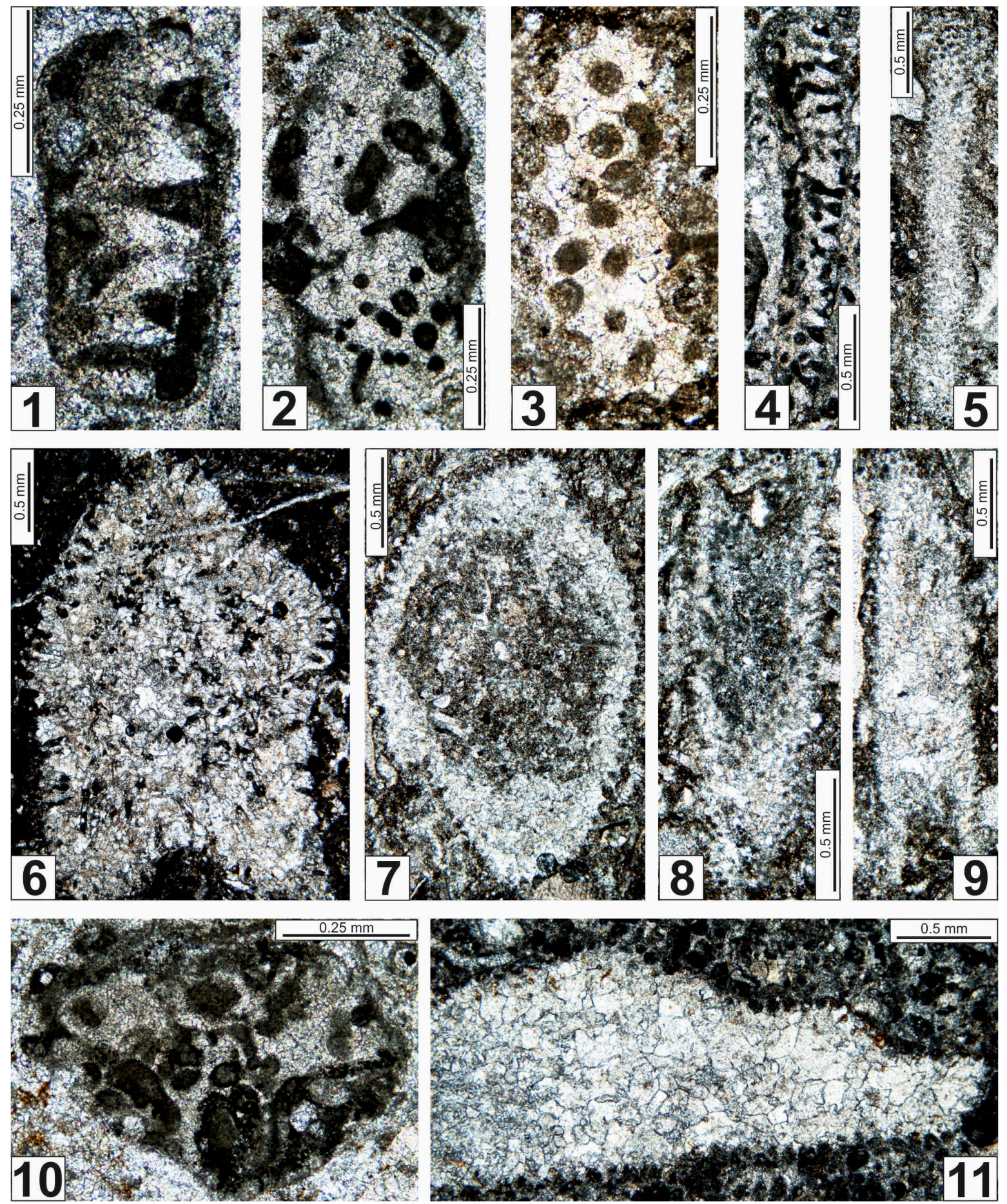

FIGURE 14. 1-4, 10. Boueina? crassundia n. sp. 1. Axial section through dilated deltoid terminations. San Andres Fm. Sample MLY(2) 6-16. 2. Oblique section through the siphons. San Andres Fm. Sample MLY(2) 5a-25. 3. Tangential sections of the siphons. Yeso Group. Sample MG(2) 12-5. 4. Subaxial sections of cortical siphons. San Andres Fm. Sample MLY(2) 6-7. 10. Subaxial section showing medullar and cortical siphons. San Andres Fm. Sample MLY(2) 5a19a. 5, 8-9. Gymnocodium? bacillum n. sp. 5. Tangential section. San Andres Fm. Sample SAR(2) 8-9. 8. Axial section. San Andres Fm. Sample SAR(2) 8-20. 9. Axial section. San Andres Fm. Sample SAR(2) 8-14. 6-7, 11. Gymnocodium? johnsonii n. sp. 6. Axial section. Yeso Group. Sample MG(2) 12-13. 7. Subaxial section without calcified medullar zone; the internal sediment contains an Eotuberitina reitlingerae Miklukho-Maklay, 1958. San Andres Fm. Sample SAR(2) 8-17. 11. Axial section completely recrystallized. San Andres Fm. Sample MLY(2) 6-14. 
Description. The thallus is small $(\mathrm{L}=1.75-3.00$ $\mathrm{mm}, \mathrm{w}=0.50-0.90 \mathrm{~mm}$ ), segmented, and our material is composed of individualized stickshaped segments. They are tapering to subcylindrical. Numerous tangled, thin medullar tubes are often preserved. Oblique cortical simple siphons with terminal deltoids ( $=$ utricles) $(p=0.01-0.02$ $\mathrm{mm}$ ). Conceptacles not observed.

Remarks. In our material, some specimens of this species are relatively similar to Gymnocodium? johnsonii n. sp. (e.g., compare the Figures 19.7 and 19.9), but differ by their smaller deltoids, other are relatively similar to true Gymnocodium (Figure 19.8-19.11) but more tapering. On the other hand, G.? bacillum $\mathrm{n}$. sp. differs from a true Gymnocodium like $G$. bellerophontis by its smaller dimensions and well-preserved medullar zones, and from Siamporidium minum (sic; probably minimum) Endo, 1969 by a less lanceolate test, well preserved medullar zone, and less ramified cortical siphons.

Occurrence. Artinskian/Kungurian of Guatemala. Kungurian of New Mexico (Yeso Group, Los Vallos Formation, Torres Member: samples MG 10-11, MG(2) 12-2; San Andres Formation: samples SAR 2-5, SAR 7-8, SAR 8-8, SAR(2) 8-9, SAR 8-14, SAR(2) 8-20, SAR 8a-3, SAR 8a-4, SAR 8a-15, SAR 8a-16, SAR 8a-23, SAR 8a-26, SAR 13-6).

Undetermined Chlorophyta

Figures 10.7, 10.8, 11.5, 13.2, 13.9, 16.3-16.5, $17.1-17.4,17.7,20.18$

v. 2013b Undetermined mastoporean? dasyclads; Vachard, Krainer and Lucas, p. 348 (no illustration).

Description. The fragments measure: $L=0.50$ $1.43 \mathrm{~mm} ; \mathrm{w}=(0.09)-0.17-0.38 \mathrm{~mm}$; they display the classical aspect of large, spherical, broken epimastoporacean thalli. The shapes of the laterals are variable in sections (Figure 16.3-16.4). The siphons or laterals are ovoid and measure 0.03$0.04 \mathrm{~mm}$ in diameter and up to $0.20 \mathrm{~mm}$ long. The L2 are cup-shaped (proximal diameter $=0.03-0.04$ $\mathrm{mm}$; distal diameter $=0.05-0.10 \mathrm{~mm}$ ).

Material. 37 specimens; illustrated are NMMNH P 67514, 67515, 67516.

Remarks. Some sections are relatively similar to those of Wagonella Mamet and Préat, 1992 from the Middle Devonian of Belgium (compare Figure 13.9 with the holotype of Wagonella). They differ from Wagonella by the shape of the laterals (cylindrical and not acrophore); and on the other hand, that might correspond to a peculiar and extreme taphonomic transformation of Boueina? crassiundia (Figures 10.8, 11.5, 16.4).

Occurrence. Early? and middle? Kungurian of New Mexico (Yeso Group, Los Vallos Formation, Torres Member: samples MG(2) 10-11a, MG 1019, MG 10-27, MG(2) 12-1, MG 12-2, MG 12-3, MG 12-3a; San Andres Formation, McLeod Hills (lower part): samples MLY 5-2, MLY 5-2a, MLY(2) 5-18, MLY(2) 5a-6a, MLY(2) 6-9, MLY(2) 6-9a, MLY(2) 6-10, MLY 6-20, MLY(2) 6-24, MLY(2) 626).

Kingdom indet.

Phylum indet.

Incertae sedis

Order TUBERITINIDA Miklukho-Maklay, 1958 nom. translat. herein

Family TUBERITINIDAE Miklukho-Maklay, 1958

Description. See Vachard (1994).

Remarks. Despite their resemblances to foraminifers, tuberitinids cannot belong to this group because of: 1) some microstructures of their wall; 2) common mutual attachment; and 3) existence of a double way of life, either free or attached (Conil and Lys in Conil et al., 1977). This latter character might indicate a relationship with the Euglenophyta but this group is not calcified, and the remarkable biological tolerance of the tuberitinids is not compatible with a protophytal ecology. As indicated by Vachard (1994), some links might exist with the calcitarcha calcisphaeraceae, but this group is also incertae sedis. Appearing in the Silurian, the tuberitinids are still common up to the Permian-Triassic Boundary (PTB) (Vachard, 1994), Very rare forms cross through the PTB, given that Song et al. (2011; and personal commun., November 2014) have identified Diplosphaerina Derville 1952 (the free stage of Eotuberitina) in the lowermost Triassic beds of South China.

Occurrence. Silurian-Permian, cosmopolitan.

$$
\begin{aligned}
& \text { Genus EOTUBERITINA } \\
& \text { Miklukho-Maklay, } 1958
\end{aligned}
$$

Type Species. Eotuberitina reitlingerae MiklukhoMaklay, 1958.

Description. Ampulliform test often showing an attachment disk. Wall thin, dark, microgranular, with very fine radial microperforations inconspicuous to obvious.

Remark. This genus has its first acme in the Middle Devonian but appears in the Early Silurian of Tajikistan (Gissar Range: Saltovskaya, 1981).

Occurrence. Early Silurian-Late Permian, cosmopolitan. 

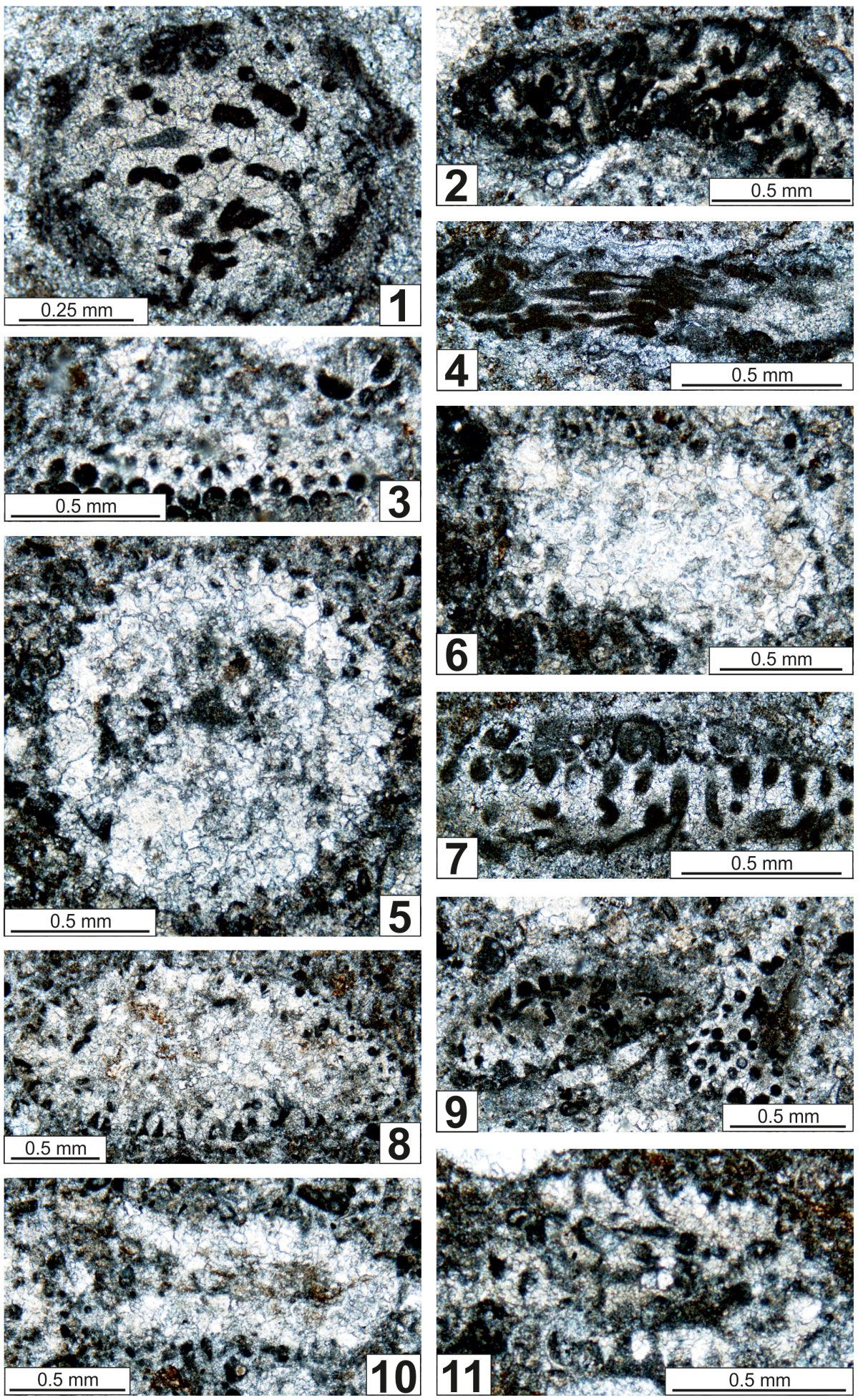

FIGURE 15. 1-2, 4, 7, 9. Boueina? crassundia n. sp. 1. Oblique subaxial section. San Andres Fm. Sample MLY 5-1. 2. Oblique section. San Andres Fm. Sample MLY 5-27. 4. Axial section. San Andres Fm. Sample MLY 5-28. 7. Atypical axial section with excessively dilated siphons of medullar zones. San Andres Fm. Sample MLY 6-8. 9. Two oblique sections with typical dilated siphons of medullar zones. San Andres Fm. Sample MLY 6-10. 3, 5-8, 10-11. Gymnocodium? johnsonii n. sp. 3. Tangential section. San Andres Fm. Sample MLY 6-6. 5. Transverse section. San Andres Fm. Sample MLY 6-11. 6. Subaxial section. San Andres Fm. Sample MLY 6-7. 7. Oblique section. San Andres Fm. Sample MLY 6-8. 8. Oblique subaxial section. San Andres Fm. Sample MLY 6-15. 10. Axial section. San Andres Fm. Sample MLY 6-12. 11. Axial section. San Andres Fm. Sample MLY 6-25. 
Eotuberitina reitlingerae Miklukho-Maklay, 1958 Figures 13.2, 13.9, 14.7, 20.9, 22.15

1950 Tuberitina maljavkini Mikhailov; Reitlinger, $p$. 88, pl. 19, figs. 2, 3 (non Mikhailov, 1939).

1958 Eotuberitina reitlingerae Miklukho-Maklay, p. 134 (nomen novum).

v. 2013b Eotuberitina reitlingerae Miklukho-Maklay; Vachard, Krainer and Lucas, p. 348 (no illustration).

Description. Eotuberitina reitlingerae is relatively rare in our material but typical with the following parameters: $\mathrm{H}=0.05-0.15 \mathrm{~mm} ; \mathrm{w}=0.13-0.17 \mathrm{~mm}$; and $\mathrm{s}=0.005-0.007 \mathrm{~mm}$.

Occurrence. Kungurian (late Leonardian) of New Mexico (Yeso Group, Los Vallos Formation, Torres Member: sample MG 12-12a; San Andres Formation; samples MLY 4-5, MLY 4-7, SAR(2) 8.7, SAR 11a-1, SAR(2) 12-15).

Kingdom indeterminate

Phylum indeterminate

Incertae sedis

Family TUBIPHYTIDAE Vachard, Krainer and Lucas, 2012

Description. Microproblematica probably constituted by the weakly to strongly transformed consortial association of cyanobacterial algae and Miliolata foraminifers. Proloculus and juvenarium are very poorly known but occasionally illustrated. Poorly transformed chambered tubes of Tubiphytes are called Cordiformis Güvenç, 1965 (nomen nudum; see Vachard and Montenat, 1981 and Vachard and Ferrière, 1991) and Nodophthalmidium Macfadyen, 1939. Typical Tubiphytes appear as masses of a rounded, thick-walled taxon with a small rounded cavity (e.g., Razgallah and Vachard, 1991; Senowbari-Daryan and Flügel, 1993); atypical Tubiphytes exhibit large cavities, integrated small tubes and other transformations of the initial foraminifer for which the specimen illustrated by Riding and Guo (1992, plate 1, figure 4) is the best example.

Composition. Tubiphytes Maslov, 1956 (= Nigriporella Rigby, $1958=$ Tubiella sensu Rauzer-Chernousova, 1949 (or 1951 fide Roux, 1985, p. 620) preoccupied $=$ Shamovella in the sense of RauzerChernousova, 1950 nomen dubium); Plexoramea Mello, 1977; Crescentiella Senowbari-Daryan et al., 2008; Latitubiphytes Vachard et al., 2012; Cordiformis Güvenç, 1965 (nomen nudum; = Incertae sedis 5 in the sense of Nguyen Duc Tien, $1979=$ Foraminifer gen. et sp. indet. in the sense of Senowbari-Daryan and Flügel, 1993); one of the Vervilleina bradyi (Spandel, 1901) illustrated by
Filimonova (2010, plate 5, figure 11); Porferitubus Senowbari-Daryan, 1984; Nodophthalmidium Macfadyen, 1939; Ramovsia Kochansky-Devidé, 1973 (= Dorudia Jenny and Jenny-Deshusses, 1978 = Apterinella in the sense of Berczi-Makk and Kochansky-Devidé, 1981 non Cushman and Waters, 1928b); ?Nubeculinella Cushman, 1930.

Remarks. As indicated by many authors (Elias, 1959; Riding and Guo, 1992), the genera Shamovella and Tubiphytes share the same stratigraphic level and type area, in the pre-Kungurian of the Urals in the Ishimbajevo oil-field, near the town of Sterlitamak, probably in the bioconstruction (shikhan) of Nizhni-Irginsk re-studied by Vennin et al. (1997). An origin in the Sylvinsk reefs, near the town of Kungur, where Tubiphytes is very common (Chuvashov, 1983), is also possible. Furthermore, the type material of Tubiphytes was collected by Maslov and Rauzer-Chernousova together (Riding, 1993). During this joint field-trip, Rauzer-Chernousova, who had created Shamovella a few years before had a valuable opportunity to promote it to Maslov. However, in his diagnosis of Tubiphytes, Maslov did not refer to Shamovella, but instead to Tubiella Rauzer-Chernousova as a preoccupied name which specifically must be replaced by Tubiphytes. After that, Rauzer-Chernousova has never contested Tubiphytes and proposed its replacement by Shamovella. We can deduce that, as soon as 1956, a consensus about Tubiphytes existed among the Russian micropalaeontologists, and, ipso facto, the unique argument of Riding (1993) and Riding and Barkham (1999) to replace Tubiphytes by Shamovella is irrelevant.

On the other hand, our studies in New Mexico confirm the synonymy of Nigriporella magna Rigby, 1958, defined in the lower Leonard Formation, with Tubiphytes obscurus (synonymy first suggested by Elliott, 1962).

The external surface of the wall of Tubiphytes is probably relatively soft (or firm, at the maximum) because, as mentioned by Vachard (1980) and Vennin et al. (1997), Tubiphytes is rarely encrusted and only by Tubiphytes, Archaeolithoporella Endo, 1959, tuberitinid microproblematica, and/or fistuliporid bryozoans. For this reason, the soft/firm wall of Tubiphytes was probably able to integrate some elements of the sea bottom: generally, sponge spicules but also some fragments of bryozoans, rare foraminifers and fragments of ungdarellacean algae (Maslov, 1956; Homann, 1972; Vachard, 1980; Vachard and Montenat, 1981; Vennin et al., 1997). Due to this character, the foraminifer included in Tubiphytes and illustrated by Krainer et 

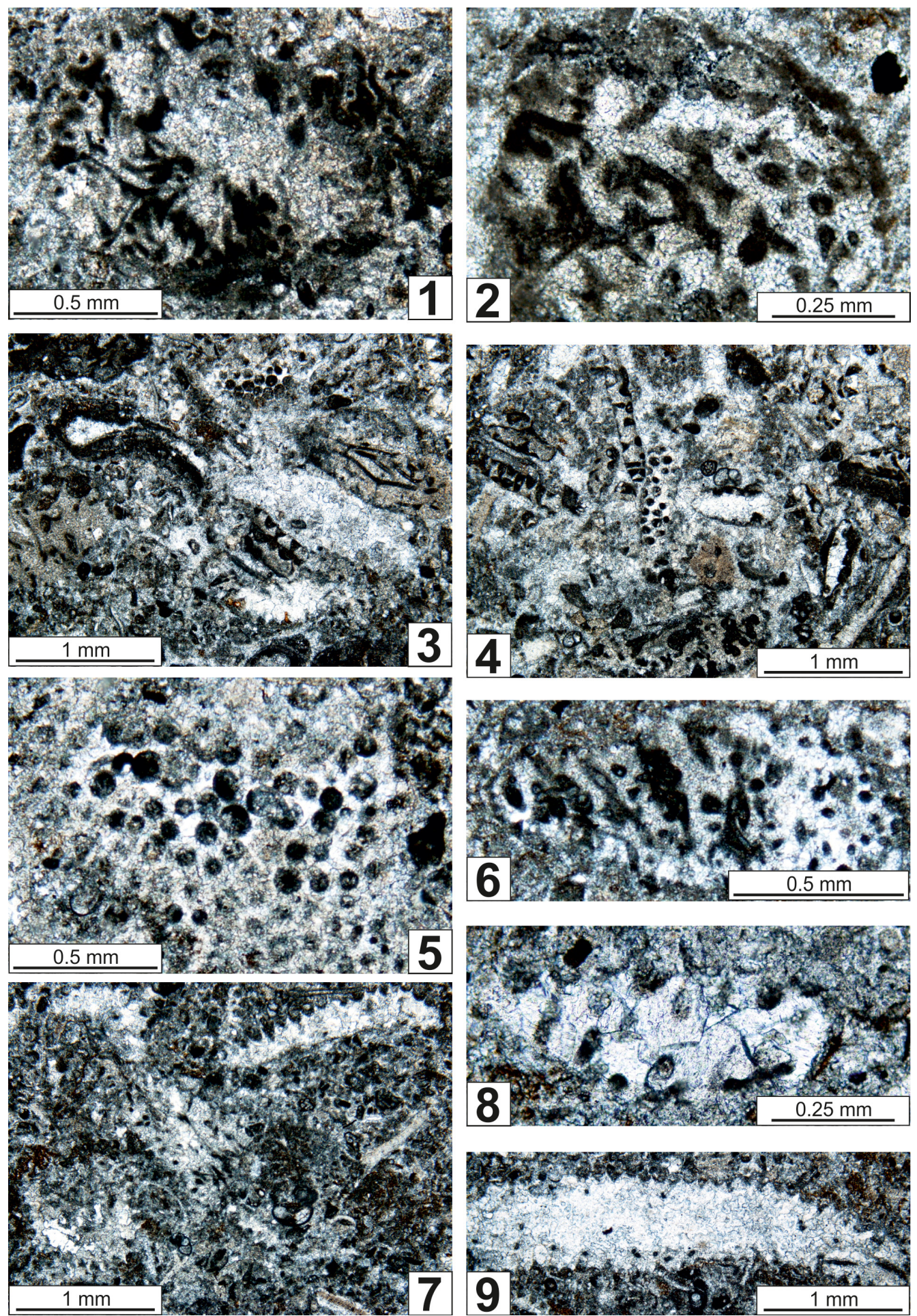

FIGURE 16. 1-2, 6, 8. Boueina? crassundia n. sp. 1. Oblique section. San Andres Fm. Sample MLY 6-13. 2. Subaxial section. San Andres Fm. Sample MLY 6-14. 6. Tangential section. San Andres Fm. Sample MLY 6-30. 8. Atypical oblique section. San Andres Fm. Sample MLY 8-3. 3-5. Undetermined Chlorophyta. 3. Two sections (centre) with Gymnocodium? johnsonii n. sp. (centre bottom and top) and Boueina? tubulata n. sp. (top right). San Andres Fm. Sample MLY 6-20. 4. At least six fragments. San Andres Fm. Sample MLY 6-21. 5. Tangential section. San Andres Fm. Sample MLY 8-5. 7, 9. Gymnocodium? johnsonii n. gen. n. sp. 7. Various sections associated with Globivalulina parapiciformis n. sp. (bottom, left) and G. novamexicana n. sp. (centre). San Andres Fm. Sample MLY 6-32. 9. Subaxial section. San Andres Fm. Sample MLY 6-27. 
al. (2009, plate 3 , figure 2 ), which is probably a Nodosinelloides netschajewi (compare with plate 5, figures 1, 2, 3, 4 in the same article), is not a boring foraminifer as suggested by Schlagintweit et al. (2013), but an included foraminifer. Another nodosariate incorporated in Tubiphytes has been illustrated by Razgallah and Vachard (1991, plate 2, figures 7,8$)$. After this soft/firm stage with the possibility of inclusion, Tubiphytes rapidly becomes strongly hard and lithified because many fragments of Tubiphytes can be reworked near the colonies in situ (Sano et al., 1990), and because these fragments can be covered by early diagenetic fibrous cements (Vennin et al., 1997).

No new data can be provided here concerning the assignment of Tubiphytes. The interpretation of Bernier (1984), Vachard et al. (2001), and Vachard and Krainer (2001b) is fundamentally different from that of Maslov (1956) and Senowbari-Daryan and Flügel (1993), because the former authors consider the internal cavity as an important part of the organism; i.e., inherited from an ancestral Miliolata foraminifer. During evolution in the late Moscovian, this ancestor (probably a species of Palaeonubecularia Reitlinger, 1950) becomes intimely associated with a cyanobacterium (in a narrow assemblage similar to a lichen, for example). During this evolution, the shape of the foraminiferal cavity trends to disappear; for example, from Latitubiphytes in the Late Pennsylvanian (KasimovianGzhelian) to true Tubiphytes in the Early Permian (Asselian-Kungurian), but it can reappear in the Late Permian with the "stages" of Tubiphytes obscurus illustrated by Senowbari-Daryan and Flügel, 1993 (text-figure 10 A-D, plate 3, figures 1, 2, $3,4,5,6,7,8,9,10,11,12,13,14,15,16$; plate 4, figures 1, 2, 5, 6) and Vachard et al., 2003 (plate 27, figures 1, 4, 5), and called Cordiformis (nomen nudum) by Güvenç (1965). Similarly, the resemblance of the cavity of Tubiphytes (now Crescentiella) morronensis Crescenti, 1969 with that of nubecularioid foraminifers has often been stressed (Bernier, 1984; Senowbari-Daryan et al., 2008).

Occurrence. Questionable references to tubiphytids in Bashkirian and early Moscovian deposits seem more related to "tolypamminid" (in fact, porcelaneous homeomorphs of these latter) foraminifers (Vachard et al., 2012). The family truly appears in the late or latest Moscovian (Chuvashov et al., 1993; Vachard et al., 2012), during which Palaeonubecularia rustica Reitlinger, 1950, true primitive tubiphytids (Latitubiphytes), and transitional forms between both genera can be found together. The typical tubiphytids are present from the Late Penn- sylvanian (Kasimovian) to Early Cretaceous (for the Mesozoic forms see Senowbari-Daryan et al., 2008).

Genus TUBIPHYTES Maslov, 1956

Type Species. Tubiphytes obscurus Maslov, 1956.

Tubiphytes epimonellaeformis $\mathrm{n}$. sp.

Figures 11.10, 12.1-12.8, 18.12, 24.8, 24.12

zoobank.org/6CFC3DB1-DD93-4AEA-81FC-8B0B92D57395

? v. 2009 Tubiphytes ("Rigidicaulis") sp.; Krainer, Lucas and Vachard, pl. 3, fig. 7.

v. 2013b Tubiphytes sp. 1; Vachard, Krainer and Lucas, p. 348 (no illustration).

Etymology. Relatively similar to Epimonella Vachard in Kolodka, Vennin, Vachard, Trocmé and Goodarzi, 2012.

Holotype. NMMNH P-67517; Figure 12.1; sample SAR 12-2.

Paratypes. NMMNH P-67518-67524; Figures 11.10, 12.2-8.

Material. 32 specimens.

Locus Typicus. NMMNH locality 8896; San Andres Formation, reference section near Rhodes Canyon in the San Andres Mountains (New Mexico).

Stratum Typicum. Late? Kungurian (latest Leonardian).

Diagnosis. Tubiphytes with large subquadratic cavities and some prominent, small, cylindrical tubes.

Description. Test elongate rarely subquadratic (Figure 12.8) encrusting a curved to cylindrical substrate, not preserved. Test surface very irregular. Lateral sides inflated. Peripheral margin rounded. Large subquadratic cavities as well as typical tubiphytid small cavities are present within the test (Figure 24.8). Some cylindrical, small tubes are prominent and evidently permit a communication with the exterior. $L=(0.50)-0.81-1.45$ $\mathrm{mm} ; \mathrm{H}=0.30-0.70 \mathrm{~mm}$; width of large cavities = (0.10-0.12)-0.20-0.63 mm; height of large cavities $=(0.05)-0.14-0.34 \mathrm{~mm}$; width of small tubes $=0.04-$ $0.08-(0.10) \mathrm{mm}$; maximal length of small tubes $=$ $0.22 \mathrm{~mm}$; large cavities wall thickness $=0.03-0.10$ $\mathrm{mm}$; small tube wall thickness $=0.01-0.02 \mathrm{~mm}$.

Remarks. To the typical forms with irregular broad cavities and prominent tubes, we can add some representatives relatively difficult to distinguish from Latitubiphytes and that also show the typical porcelaneous recrystallization "en dents de peigne" (fine-tooth comb-shaped) of Gargouri and Vachard (1988). This observation provides further evidence of a more or less direct relationship with the Miliolata (see also Tubiphytes sp. sensu Krainer et al. 

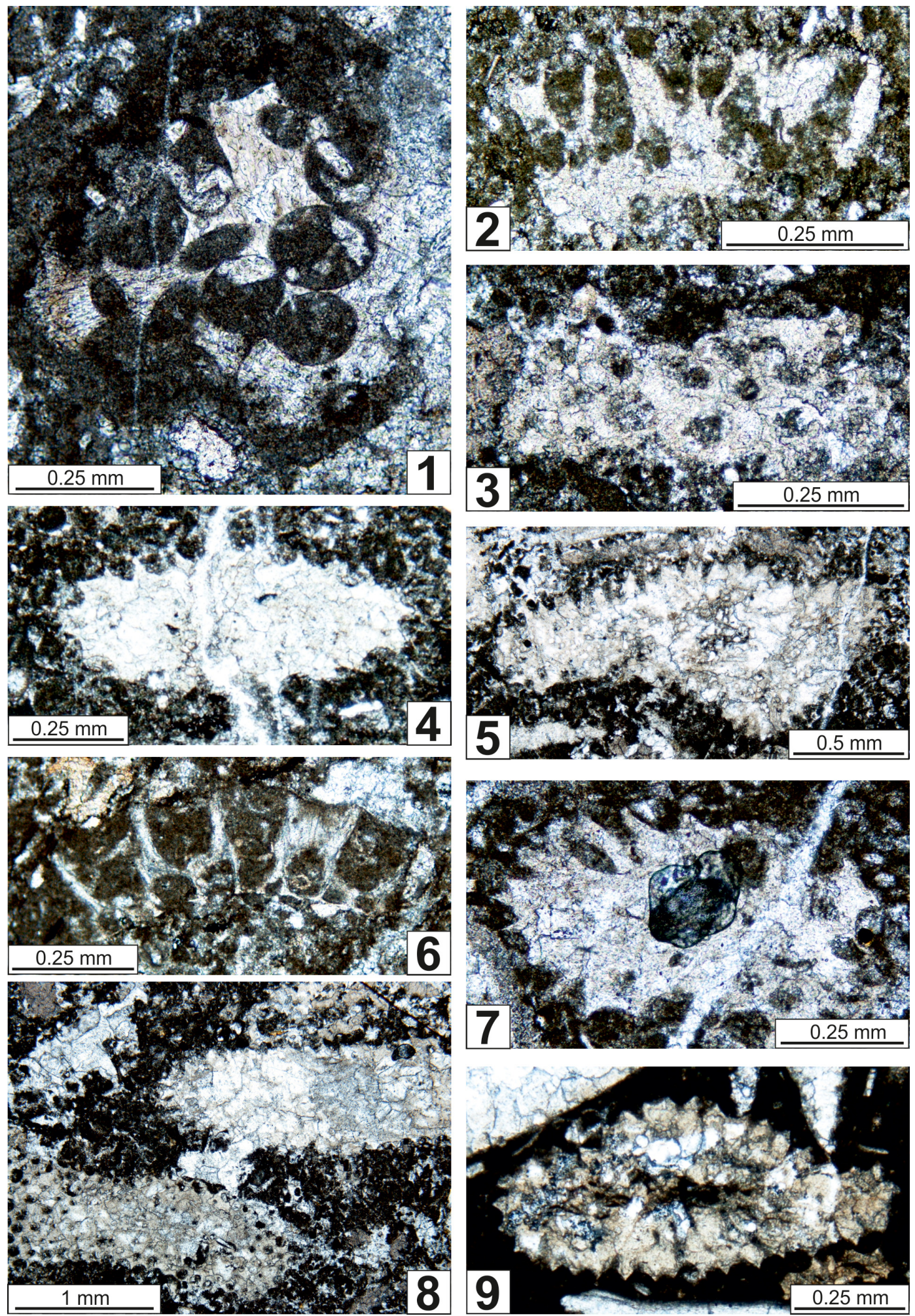

FIGURE 17. 1-4, 7. Undetermined Chlorophyta. 1. Tangential section. Yeso Group. Sample MG 10-27. 2. Subaxial section. Yeso Group. Sample MG 12-2. 3. Tangential section. Yeso Group. Sample MG 12-3. 4. Subaxial section. Yeso Group. Sample MG 12-8. 7. Oblique subaxial section. Yeso Group. Sample MG 12-3a. 6. Bryozoa. Subaxial section. Yeso Group. Sample MG 12-10. 5, 8-9. Gymnocodium? johnsonii n. sp. 5. Subaxial section. Yeso Group. Sample MG 12-5. 8. Two specimens in subaxial and tangential sections. Yeso Group. Sample MG 12-9 (already illustrated in Lucas et al., 2013b, figure 8H). 9. Subaxial section. Yeso Group. Sample MG 13e. 
(2003, plate 60, figure 4)); and with these tubiphytids, probably Latitubiphytes, illustrated under the name Vermiporella nipponica by Flügel (1966, plate 8 , figure 3 ).

The taxon has also possibly been illustrated as Galaenella? sp. by Kobayashi (2001, plate 2, figure 13) from the earliest Middle Permian of S-W Japan; but this specimen may also correspond to a non-skeletal aggregate grain in the sense of Flügel (2004).

No inclusions in the wall (as described above for typical Tubiphytes) have been observed in Tubiphytes epimonellaeformis $\mathrm{n}$. $\mathrm{sp}$. With all these particularities, $T$. epimonellaeformis $\mathrm{n}$. sp. constitutes a very atypical trend among the tubiphytids, and it is suggested here as the ancestor of the genus Epimonella Kolodka et al., 2012, which is another unusual tubiphytid.

The cavities of Tubiphytes epimonellaeformis can be explained by comparison with some marine species of Rivularia Agardh ex Bornet and Flahault, 1886 , or by an incomplete distribution of the calcium carbonate, where the older thalli are hollow and occupied by gas (Fritsch, 1945, p. 840), or by an incomplete distribution of the calcium carbonate precipitated in vivo in the cyanobacterial part of the wall (compare with Altermann et al., 2006, figure 3A-D).

Numerous small cylindrical tubes without apparent connections with Tubiphytes have been illustrated by Flügel et al. (1984, plate 31, figure 6 , plate 42 , figures $8,9,10)$ and Noé $(2003$, plate 18 , figures 7, 8; plate 19, figures $1,2,3,4,5)$. Senowbari Daryan and Flügel (1993, plate 2, figure 3) illustrated an "extended tube passing through younger segments." The connected small tubes are present in several reconstructions of Tubiphytes provided by Wang et al. (1994, figure 7.3-4, 9 ). The figure 7.9 of these authors is externally very similar to $T$. epimonellaeformis; nevertheless, the internal aspect of this specimen is not given, and the other illustrated sections (figures 8.1-11, 11.1-8) more likely correspond to $T$. obscurus or $T$. carinthiacus.

Comparison. This form appears to be transitional between true Tubiphytes and Epimonella because of the tubular expansions of the hemispherical masses.

Some parts are similar to Tubiphytes obscurus, and the other ones show large cavities totally unknown in the latter species.

The new species appears relatively similar to Palaeonubeculata (sic) fluxiformis Igonin, 1998 in the dimensions of the larger cavities and the strati- graphic occurrence ( $P$. fluxiformis is known from the Kungurian of the Northern Pre-Urals and Pechora Basin), but apparently the small open tubes are not present in this species.

The new species is relatively similar to Tubiphytes ("Rigidicaulis") sensu Krainer et al. (2009, plate 3 , figure 7 ), which is older.

Occurrence. Late? Kungurian (latest Leonardian) of New Mexico (San Andres Formation, reference section: samples SAR 3-3, SAR 8a-22, SAR(2) 116, $\operatorname{SAR}(2)$ 11-8, $\operatorname{SAR}(2)$ 11-9, $\operatorname{SAR}(2)$ 11-12, SAR(2) 12-1, SAR 12-3, SAR(2) 12-3, SAR(2) 123a, SAR(2) 12-5, SAR(2) 12-7, SAR(2) 12-8, $\operatorname{SAR}(2)$ 12-9, SAR(2)12-10, SAR(2) 12-12, SAR(2) 12-13).

\section{Kingdom indeterminate \\ Class, Order and Family incertae sedis Genus ELLESMERELLA Mamet and Roux in \\ Mamet, Roux and Nassichuk, 1987 emend. Vachard and Krainer, 2001b}

Type Species. Girvanella permica Pia, 1937.

Description. Encrusting groups of tubular chambers, forming flat nodules or oncoids. These elongate cylindrical undivided chambers are arranged parallel to each other in subhorizontal or roughly concentric layers. Their diameter varies due to the presence of pseudoconstrictions. The basal part of the tubular chambers is flatter than the upper part, which is more rounded.

Remarks. Ellesmerella has been interpreted as an atypical foraminifer by Vachard and Krainer (2001b). Further unpublished observations of the same authors, on specimens of the Grenzland Fm of the Carnic Alps, provide evidence of a porcelaneous wall in the well-preserved specimens. The girvanellacean nature of this taxon thus might be definitely abandoned, because the wall of this cyanobacterial group is dark-microgranular, but never porcelaneous; a type of wall apparently only known among the miliolate foraminifers. Ellesmerella is therefore more similar to nubeculariid foraminifers than girvanellacean trichomes. Ellesmerella is probably present in the literature under several names: Girvanella auctorum (partim), Nubecularioidea (partim), Osagia (partim), Ottonosia (partim), and Clinortonella Vachard and Moix, 2013. If Ellesmerella was easily confused with cyanobacteria (Girvanella, Clinoortonella, etc.), that is probably because porcelaneous walls are very rarely preserved (as in the Zweikofel Formation of the Carnic Alps; Vachard and Krainer, unpublished data), and because, almost always, it diagenetically becomes microgranular and similar to an ontogenic girvanellacean wall. 

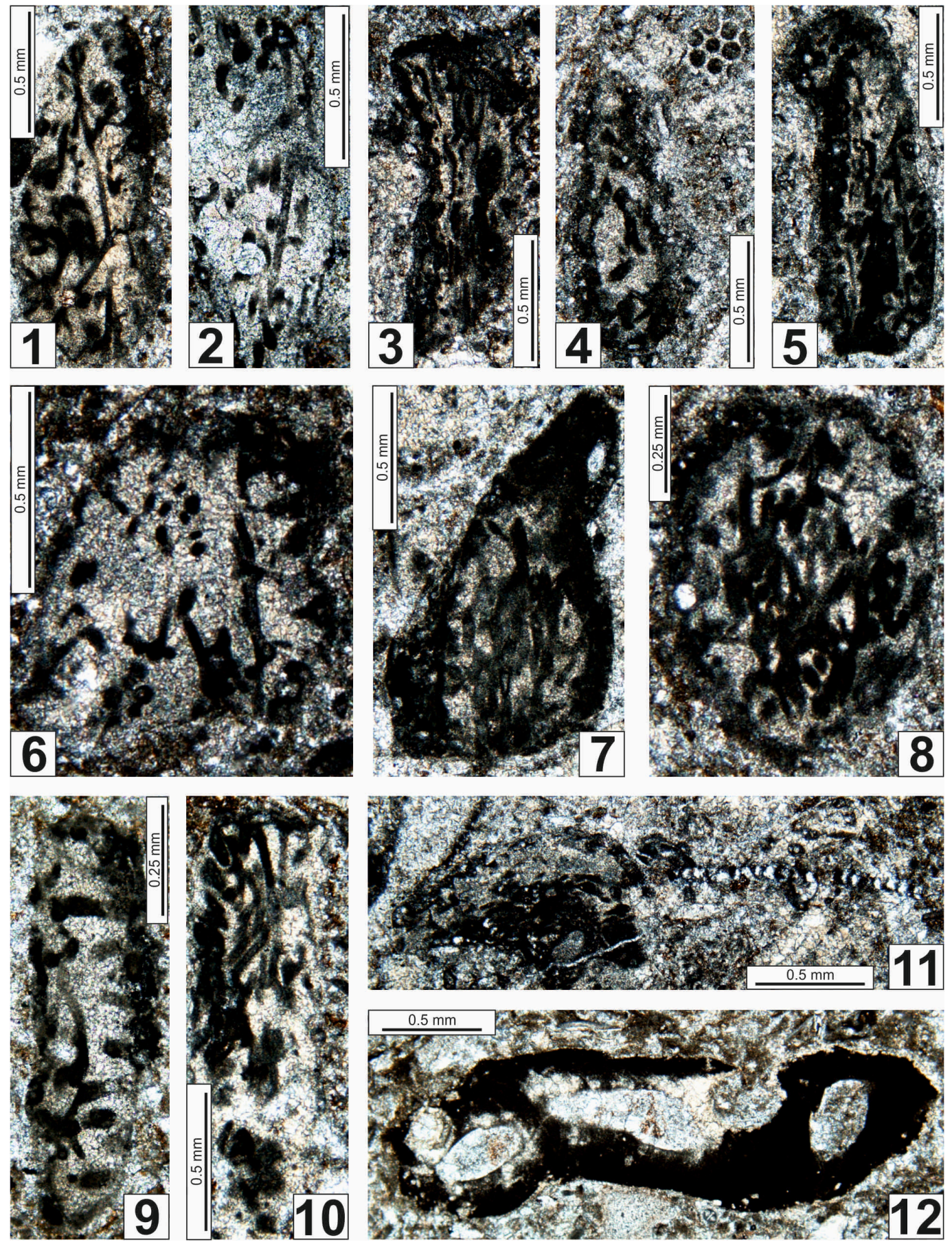

FIGURE 18. 1-5. Boueina? tubulata n. sp. 1. Axial section. San Andres Fm. Sample MLY(2) 5a-26. 2. Axial section. San Andres Fm. Sample MLY(2) 5a-9. 3. Subaxial section. San Andres Fm. Sample MLY(2) 5a-2. 4. Oblique section. San Andres Fm. Sample MLY 5-18. 5. Subaxial section. San Andres Fm. Sample MLY(2) 5-19. 6-11. Boueina? crassundia n. sp. 6. Axial section. San Andres Fm. Sample MLY(2) 5-9. 7. Axial section. San Andres Fm. Sample MLY(2) 5-19d. 8. Oblique section. San Andres Fm. Sample MLY(2) 5-11. 9. Oblique subaxial section. San Andres Fm. Sample MLY(2) 5-16. 10. Longitudinal section. San Andres Fm. Sample MLY(2) 5-14. 11. Oblique section (left). San Andres Fm. Sample MLY(2) 5a-12. 11. Gymnocodium? johnsonii n. sp. An axial section through the cortical zone (right). San Andres Fm. Sample MLY(2) 5a-12. 12. Tubiphytes epimonellaeformis n. sp. Specimen similar to Latitubiphytes Vachard, Krainer and Lucas, 2012 exhibiting a neosparitization of Miliolata, especially Hemigordiopsis, Baisalina or Pseudobaisalina (see Gargouri and Vachard, 1988; Vdovenko et al., 1993). San Andres Fm. Sample SAR(2) 12-15. 
Finally, it is interesting to notice that three groups of Permian Miliolata are very transformed and exhibit some resemblances with algae or cyanobacteria: ellesmerellids, tubiphytids, and pseudovermiporellids. These three groups, although abundant, are difficult to palaeobiologically interpret because their descendents (or at least homeomorphs) are absent from the modern seas.

Occurrence. Early Permian, cosmopolitan (see Vachard and Krainer, 2001b, p. 190).

\section{Ellesmerella rara n. sp. \\ Figure 10.1-10.3}

zoobank.org/08ED08A8-233B-451D-9B66-6339DF25B309

v. 2013b Ellesmerella sp. 1; Vachard, Krainer and Lucas, p. 348 (no illustration).

Etymology. Latin rarus, rare.

Holotype. NMMNH P-67501; Figure 10.1-2; sample MG 13c-d.

Paratypes. NMMNH P-67502; Figure 10.3.

Material. 3 specimens (samples MG 13 c-d, i).

Locus Typicus. NMMNH locality 8891; Yeso Group, Los Vallos Formation, Torres Member, Massacre Gap in the southern Fra Cristobal Mountains (New Mexico).

Stratum Typicum. Early? Kungurian (late Leonardian).

Diagnosis. An Ellesmerella constituting some small ovoid sets of attached trichomes without encrustation of an exotic nucleus.

Description. The whole colony is elongate to ovoid $(L=0.47-0.50 \mathrm{~mm}$; $w=0.10-0.65 \mathrm{~mm}$ ); it is composed of 4-5 whorls of roughly concentric rows of very low, undivided pseudochambers measuring $D=0.04-0.05 \mathrm{~mm} ; \mathrm{d}=0.03 \mathrm{~mm} ; \mathrm{I}=0.16-0.33 \mathrm{~mm}$; and $\mathrm{s}=0.01-0.02 \mathrm{~mm}$.

Remarks. Ellesmerella permica is distinct in constituting large oncoids around elongate nuclei (e.g., bivalve or brachiopod shell fragments or Anchicodium phylloid algae), which are common from the Carnic Alps (Austria-Italy) to Alborz (Iran); moreover, its pseudochambers are shorter and smaller $(I=0.30-0.40 \mathrm{~mm}$ (rarely $0.11 \mathrm{~mm})$ and $\mathrm{d}=$ 0.01-0.02 $\mathrm{mm}$ according to Flügel, 1966).

Occurrence. Early? Kungurian (late early Leonardian) of New Mexico (Yeso Group, Torres Member).

Phylum RHIZARIA Cavalier-Smith, 2002

Subphylum FORAMINIFERA d'Orbigny, 1826 nom. translat. Cavalier-Smith, 2003

Class FUSULINATA Möller, 1878 nom. translat. Gaillot and Vachard, 2007

Subclass FUSULININA Möller, 1878 nom. translat.
Vachard, Pille and Gaillot, 2010

Order ENDOTHYRIDA Brady, 1884 nom. translat. Fursenko, 1958

Superfamily GLOBIVALVULINOIDEA Reitlinger, 1950 nom. translat.

Hance, Hou and Vachard, 2011

Family GLOBIVALVULINIDAE Reitlinger, 1950 nom. translat. Gaillot and Vachard, 2007

Subfamily GLOBIVALVULININAE Reitlinger, 1950 orth. mut. Pokorny, 1958

Genus GLOBIVALVULINA Schubert, 1921

Type Species. Valvulina bulloides Brady, 1876.

Description. Test planispirally and biserially coiled; occasionally initially trochospiral. Coiling entirely involute, rarely semi-involute to evolute. Test subspherical to nautiloid, rarely ovoid. The ventral side is flattened to concave; the dorsal side is strongly convex to slightly curved. Proloculus spherical, more or less large and more or less inserted in the inner whorls. Few whorls (1-3) and relatively few chambers (6-10). Chambers inflated to triangular. Diameter small to medium, rarely large in Middle and Late Permian species (0.25$1.00 \mathrm{~mm}$ ). Septa complete and well-curved. Umbilicus slightly depressed to absent. A diversely developed oral valvula (or valvular projection) is present in the last chamber. Wall unilayered (microgranular or microgranular with a calcareous agglutinate) or bilayered (with a pseudofibrous inner layer discontinuously present). The described "diaphanotheca" seems only to correspond to a luminothecalike wall or even a diagenetic differentiation of the medium to thick microgranular walls. Aperture low, arched, central or peripheral at the extremity of a funnel diversely developed.

Remarks. For the phylogeny of this genus, see Vachard et al. (2006), Gaillot and Vachard (2007), and Cózar and Somerville (2012).

Although repetitively revised, the type species Globivalvulina bulloides remains under discussion, especially, its true aspects in transverse and axial sections. These types of section are perhaps more accurately known in G. moderata Reitlinger, 1949, which has been synonymized with $G$. bulloides by Groves (1988) or Harris et al. (1997). Globivalvulina moderata sensu stricto differs by its smaller dimensions, and a microgranular wall that is never differentiated, but $G$. bulloides sensu Potievskaya, 1962 (p. 65-66, plate 4, figures 7, 8, 10, 11) is truly a G. ex gr. moderata. Geometrically, the best and most complete illustrations of $G$. bulloides have probably been provided by Kulagina et al. (1992, plate 4 , figures $3,4,8$; plate 8 , figures 4,5 ; plate 9 , figure 28; plate 13 , figures $23,24,25$ ). Among the 


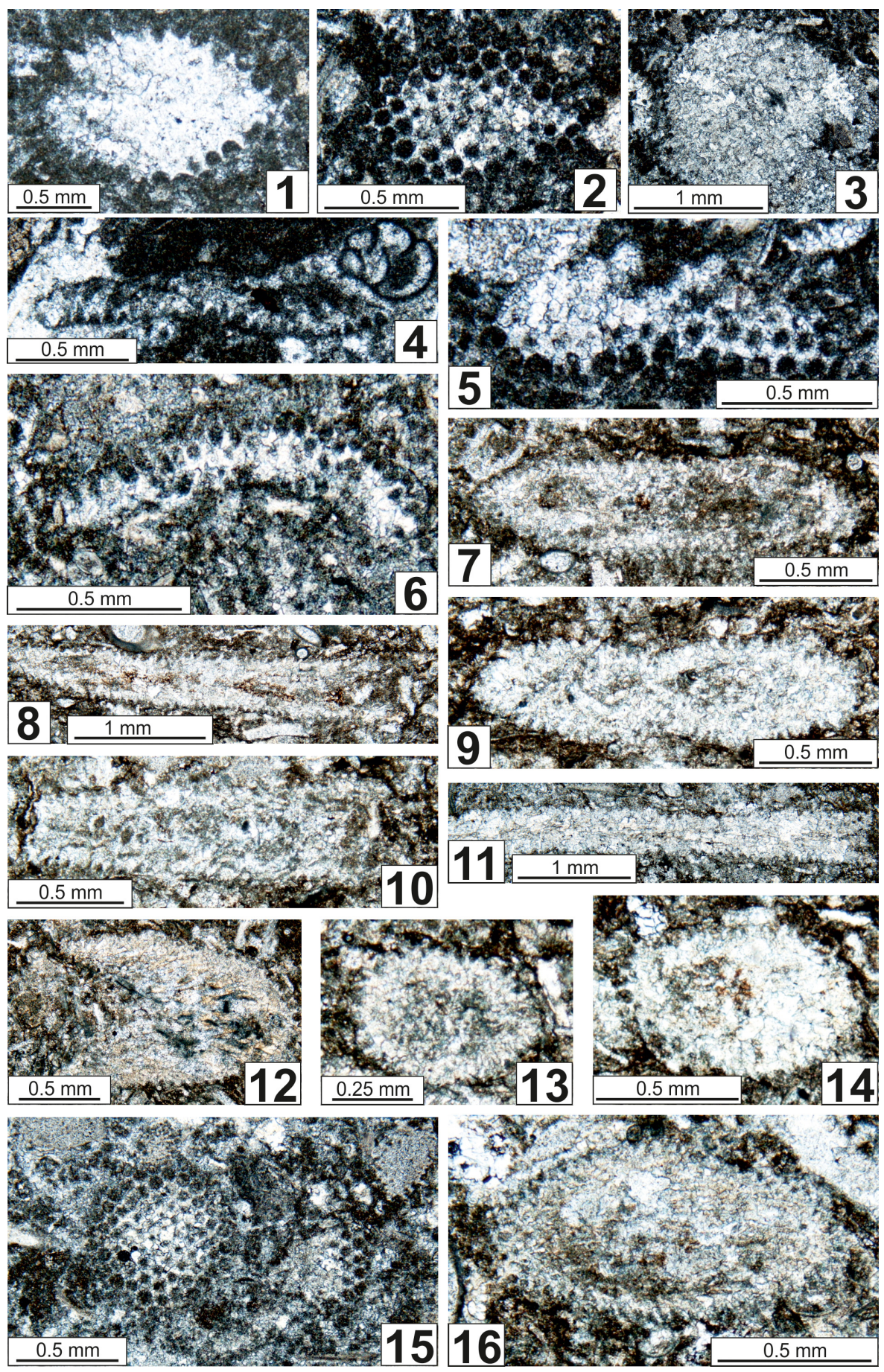

FIGURE 19. 1-2, 4-6, 9. Gymnocodium? johnsonii n. sp. 1. Subaxial section. San Andres Fm. Sample SAR 2-1. 2. Tangential section. San Andres Fm. Sample SAR 2-2. 4. Subaxial section. San Andres Fm. Sample SAR 2-3. 5. Tangential section. San Andres Fm. Sample SAR 2-4. 6. Subaxial section. San Andres Fm. Sample SAR 7-9. 9. Subaxial section. San Andres Fm. Sample SAR 8a-25 (already illustrated in Brose et al., 2013, figure 6.9). 3, 7-8, 10-16. Gymnocodium? bacillum n. sp. 3. Oblique subaxial section. San Andres Fm. Sample SAR 2-5. 7. Subaxial section. San Andres Fm. Sample SAR 8a-3. 8. Axial section. San Andres Fm. Sample SAR 8a-26. 10. Axial section. Yeso. Sample MG(2) 12-2 (already illustrated in Lucas et al., 2013b, figure 8D). 11. Axial section. San Andres. Sample SAR 8-8. 12. Axial section. San Andres Fm. Sample SAR 13-6. 13. Subaxial section. San Andres Fm. Sample SAR 8a-16. 14. Subaxial section. San Andres Fm. Sample SAR 8a-15. 15. Two tangential sections. San Andres Fm. Sample SAR 78. 16. Subaxial section. San Andres Fm. Sample SAR 8a-23. 
Pennsylvanian species of North America, G. gaptankensis Harlton, 1928 (p. 308-309, plate 53, figure. 3a-c) might be a synonym of $G$. bulloides, because $G$. bulloides, based on our collection materials can be described as follows: test subhemispherical ("similar to Globigerina" according to the diagnosis of Brady, 1876) with a trochospirally coiled axis of biseriality; dorsal size moderately convex; round peripheral margin; lateral sides strongly convex to slightly compressed to the flanks; umbilicus absent; proloculus spherical medium-sized $(0.04 \mathrm{~mm}) ; \mathrm{D}=(0.17)-0.30-0.50$ $\mathrm{mm} ; \mathrm{w}=(0.19-0.21)-0.25-0.42-(0.47) \mathrm{mm} ; \mathrm{w} / \mathrm{D}=$ $0.96-1.17$; 1.5 whorl; $4-7$ (8) chambers at last whorl, very inflated, almost spherical, and with $\mathrm{h}=$ (0.07-0.09)-0.10-0.14-(0.20) $\mathrm{mm}$; sutures curved, moderately deep; septa thin, typically globivalvulinid; ventral side flattened; aperture elongate, oblique, at the base and center of apertural face; oral valvula small in each chamber of last whorl or "heavy, strongly overlapping" (Armstrong and Mamet, 1977); funnel short or absent; wall microgranular (eventually diagenetized with diaphanotheca-like median layer; Armstrong and Mamet, 1977; Brenckle et al., 1997); $\mathrm{s}=0.01-0.02 \mathrm{~mm}$.

Occurrence. Late Mississippian (Serpukhovian)latest Permian (Changhsingian); cosmopolitan.

Globivalvulina parapiciformis $\mathrm{n}$. $\mathrm{sp}$.

Figures. 22.6, 25.3, 26.1, 26.4-26.7, 26.9, 26.11$26.14,26.16-26.19,26.21,26.23,26.25,27.10$, $27.11,28.13,30.5$

zoobank.org/479D2317-2E48-4ADA-897A-D2C035CDC48D

v. 2003 Globivalvulina spp.; Krainer, Vachard and Lucas, pl. 6, figs. 18, 22, 23, 28, 29, 32.

v. 2003 Globivalvulina bulloides Brady; Krainer, Vachard and Lucas, pl. 7, figs. 3, 9, 15, 16, $17,18,19,32$.

v. 2009 Globivalvulina cf. apiciformis Zolotova and Baryshnikov; Krainer, Lucas and Vachard, pl. 5, figs. 17, 18, 19, 20.

v. p. 2013 Globivalvulina; Brose, Lucas and Krainer, fig. 6.6 (only, non fig. $6.7=$ G. retroseptata n. sp.).

v. 2013b Globivalvulina cf. apiciformis Zolotova and Baryshnikov; Vachard, Krainer and Lucas, p. 348 (no illustration).

Etymology. Relatively similar to G. apiciformis Zolotova in Zolotova and Baryshnikov, 1980.

Holotype. NMMNH P-67551; Figure 22.6; sample MLY 4-3.

Paratype. NMMNH P-67552; Figure 25.3.

Material. 50 sections.
Locus Typicus. NMMNH locality 8897; San Andres Formation, McLeod Hills, southern Caballo Mountains (New Mexico).

Stratum Typicum. Middle? Kungurian (late Leonardian).

Diagnosis. Small Globivalvulina with an unilayered wall, early planispirally coiled axis of biseriality, hemispherical to trapezoidal chambers and basal aperture with long funnel.

Description. Test small, subnautiloid; $D=(0.17)$ $0.22-0.53 \mathrm{~mm} ; \mathrm{w}=0.18-0.43 \mathrm{~mm} ; \mathrm{w} / \mathrm{D}=0.91-1.08$. Subplanispirally coiled axis of biseriality. Proloculus spherical, small to large-sized $(0.02-0.03$ up to 0.06-0.08 mm), not inserted, not prominent. Dorsal side moderately convex. Sutures poorly- to moderately marked. Whorls: $1-1.5$. Peripheral margin rounded. Lateral sides of spire inflated. Umbilicus absent. Chambers: 5-6 (rarely 7-8) pairs, hemispherical to trapezoidal; relatively irregular in shape $\mathrm{h}=$ (rarely 0.06 ) $-0.10-0.13$ (rarely 0.17 $0.22) \mathrm{mm}$. Septa complete, well curved, in the continuity of the wall. Ventral side concave. Aperture basal with a long funnel. Oral valvula often well developed. Wall microgranular, moderately thick; $\mathrm{s}=0.01-0.02 \mathrm{~mm}$.

Comparison. Differs from G. apiciformis, a coeval species from the Kungurian (Filipovsky horizon) of the Urals (Russia), by less chambers for a similar diameter, a smaller proloculus, higher chambers, and a more compressed axial section. It differs from G. sossipatrovae Baryshnikov in Zolotova and Baryshnikov, 1980 by a longer funnel, and from $G$. uncinata Zolotova in Zolotova and Baryshnikov, 1980 by larger dimensions and thinner walls. It is probable that these three latter Kungurian species and G. parapiciformis n. sp. constitute a morphological and phylogenetic group of species or a plexus.

Occurrence. Kungurian (late Leonardian) of New Mexico (San Andres Formation, McLeod Hills (MLY) and reference section in the San Andres Mountains (SAR): samples MLY 2-1, MLY 3-4, MLY 3-7, MLY 3-9, MLY 4-3, MLY 4-4, MLY 4-10, MLY(2) 4-11, MLY 4-14, MLY 5-7c, MLY 5-7d, MLY 5-11, MLY 5-11a, MLY 5-20a, MLY 5-24a, MLY(2) 5a-6a, MLY 6-2, MLY 6-3, MLY 6-4, MLY 6-9, MLY 6-11a, MLY 6-12a, MLY 6-16, MLY(2) 6-17, MLY 624, MLY 6-31, MLY 8-2, SAR 7-6, SAR(2) 8-1, SAR 8a-8a, SAR(2) 12-18, SAR 13-9, SAR(2) 13a-4a, SAR(2) 13a-5, SAR 13a-6, SAR 13a-7, SAR 20-3, SAR 20-4).

Globivalvulina retroseptata n. sp.

Figures 21.1-21.8, 27.1, 27.4, 27.9, 27.20, 28.1- 

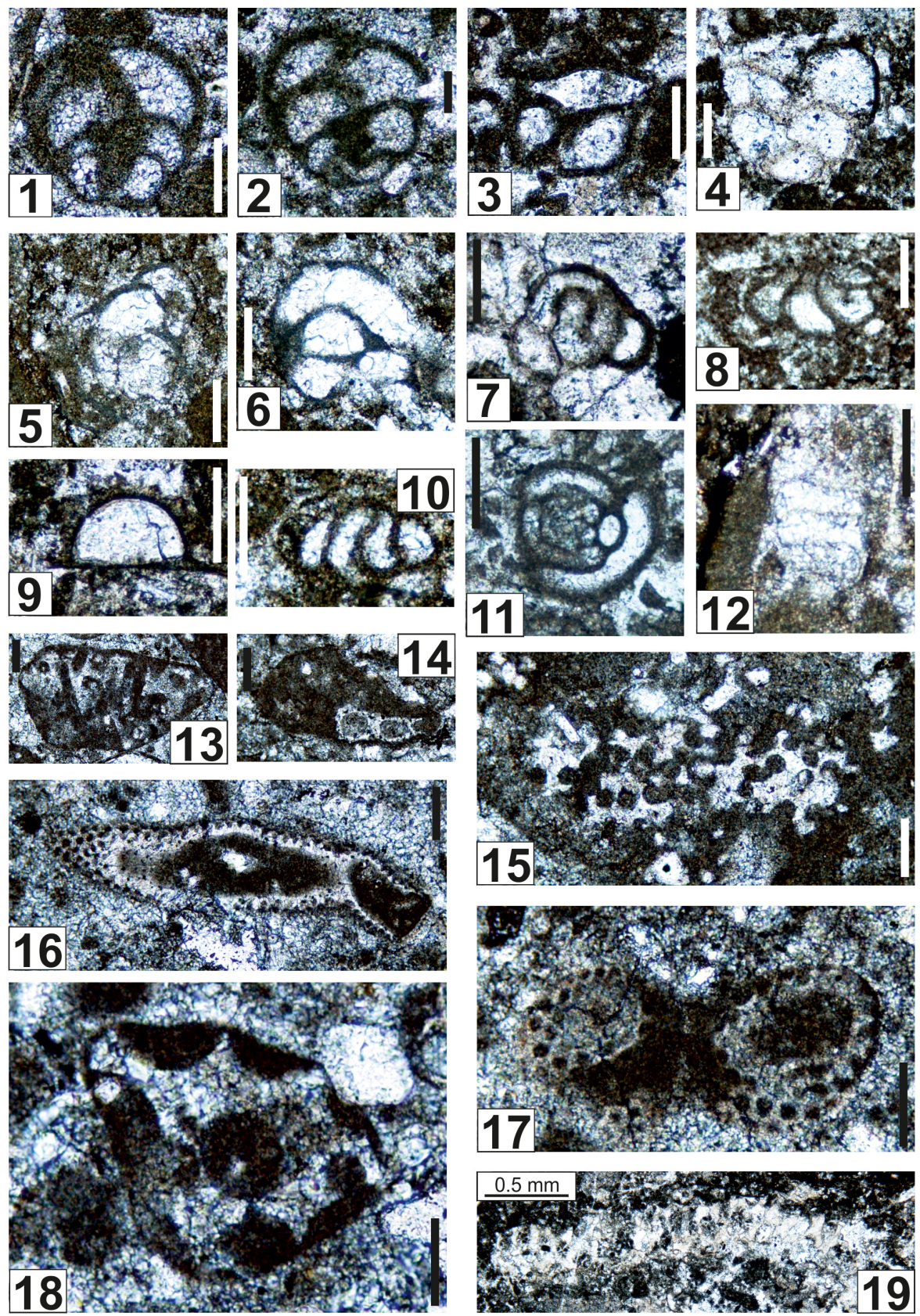

FIGURE 20. 1-4. Globivalvulina novamexicana n. sp. 1. Subaxial section. Yeso Group. Sample MG 10-18. 2. Subaxial section. Yeso Group. Sample MG 10-19a. 3. Oblique section. Yeso Group. Sample MG 12-1. 4. Recrystallized subaxial section. Yeso Group. Sample MG 12-4. 5-8, 10-11. Hemigordiellina aff. simplex (Harlton, 1928). 5. Random section. Yeso Group. Sample MG 10-23. 6. Random section. Yeso Group. Sample MG 12-7. 7. Random section. Yeso Group. Sample MG 12-11. 8. Random section. Yeso Group. Sample MG 12-12. 10. Random section. Yeso Group. Sample MG 12-13. 11. Random section. Yeso Group. Sample MG 12-14. 9. Eotuberitina reitlingerae Miklukho-Maklay, 1958. Axial section with basal disk. Yeso Group. Sample MG 12-12a. 12. Geinitzina indepressa Cherdyntsev, 1914. Subaxial section. Yeso Group. Sample MG 12-13a. 13, 15. Boueina? crassundia n. gen. n. sp. 13. Oblique section. Yeso Group. Sample MG 10-1. 15. Tangential section. Yeso Group. Sample MG 10-10. 14. Palaeonubecularia sp. Subaxial section. Yeso Group. Sample MG 10-5. 16. Gymnocodium? bacillum n. sp. Axial section. Yeso Group. Sample MG 10-11. 17, 19. Gymnocodium? johnsonii n. sp. 17. Two transverse sections. Yeso Group. Sample MG 10-13. 19. Subaxial section. Yeso Group. Sample MG 12-4a. 18. Undetermined Chlorophyta. Subtransverse section through the laterals. Yeso Group. Sample MG 10-19. Scale bars 1-12 equal 0.10 mm; $13-19$ equal $0.50 \mathrm{~mm}$. 
28.3, 28.7, 29.1-29.4, 29.7, 30.2, 30.3, 30.11, $30.13,30.16,31.9-31.12,32.1-32.3,32.6$

zoobank.org/BD9C7144-0795-47E1-84FD-6CCA76E1E64E

v. 2003 Globivalvulina spp. (partim); Krainer, Vachard and Lucas, pl. 8, figs. 2, 12.

v. p. 2013 Globivalvulina; Brose, Lucas and Krainer, fig. 6.7 (only, non fig. $6.6=G$. parapiciformis $\mathrm{n}$. sp.).

v. 2013b Globivalvulina aff. kamensis Reitlinger; Vachard, Krainer and Lucas, p. 348 (no illustration).

Etymology. With septa turned backwards (relatively similar to those of the genus Retroseptellina Gaillot and Vachard, 2007).

Holotype. NMMNH P-67553; Figure 21.4; sample SAR 13-2.

Paratypes. NMMNH P-67554-67560; Figure 21.13, 21.5-8.

Material. 35 sections.

Locus Typicus. NMMNH locality 8898; San Andres Formation, reference section, San Andres Mountains near Rhodes Canyon (New Mexico).

Stratum Typicum. Late? Kungurian (latest Leonardian).

Diagnosis. Test medium-sized, often ovoid, with septa curved backward, funnel wide and shallow, and thin microgranular wall.

Description. Test ovoid to rounded trapezoidal; D $=(0.23)-0.30-0.60 \mathrm{~mm} ; \mathrm{w}=0.28-0.55 \mathrm{~mm} ; \mathrm{w} / \mathrm{D}=$ $0.63-1.25$. Planispiral to trochospiral axis of biseriality. Proloculus spherical, small to medium-sized (0.03-0.08 mm; mainly $0.06-0.07 \mathrm{~mm}$ ), moderately large, centred. Dorsal side gently curved, strongly convex with weak sutures, to irregular and humped. Sutures moderately deep to deep. Whorl: 11.5. Peripheral margin semicircular to crescentic. Lateral sides of spire relatively flat. Umbilicus absent. Chambers: (4)-5-6-(rarely 8) pairs, semicircular to rounded, eventually deformed; the two last chambers are disproportionate with a strong increase in height as in Globivalvulina graeca Reichel, 1946 ( $h=$ (rarely 0.11)-0.13-0.30 $\mathrm{mm}$ ). Septa thin and curved backwards at their distal extremity. Ventral side flat to slightly concave. Aperture is a basal slit. Funnel wide and shallow. Oral valvula variously developed, from faint to developed, as in G. kamensis Reitlinger, 1950. Wall thin, dark, undifferentiated, unilayered, and microgranular ( $\mathrm{s}=0.01-0.02 \mathrm{~mm}$ ).

Remarks. The new species differs from all other species of Globivalvulina (except for those assigned to Retroseptellina) by the curvature of septa. Some transverse sections are difficult to dis- tinguish from G. kamensis (nevertheless, the axial sections of this species are poorly known), generally smaller with a diameter of $0.43-0.50 \mathrm{~mm}$ for Reitlinger (1950) and $0.43 \mathrm{~mm}$ according to Bogush (1963, p. 60). Although synonymized with Globivalvulina bulloides by Groves (1988), G. kamensis differs by its smaller dimensions, stronger valvular projections, and a microgranular wall that is never differentiated.

Occurrence. Kungurian (late Leonardian) of New Mexico (Yeso Group, Los Vallos Formation, Torres Member, Massacre Gap (MG): samples MG 10-9, MG(2) 10-12; and San Andres Formation, McLeod Hills (MLY) and reference section in the San Andres Mountains (SAR): samples MLY 5-3, MLY 5-23, MLY(2) 5a-5a, MLY(2) 6-13, MLY(2) 6-31, MLY 8-2a, SAR 3-1, SAR 3-4, SAR 8a-19, SAR 103, SAR(2) 12-6, SAR 13-2, SAR 13-5b, SAR 13-5c, SAR 13-7, SAR 13-10, SAR(2) 13a-1, SAR(2) 13a2, SAR 13a-7, SAR 13a-8, SAR 13a-9, SAR 13a10, SAR 13a-11, SAR 19-2, SAR 19-3, SAR 19-4, SAR 20-1, SAR 20-6, SAR (A-1§)).

Globivalvulina novamexicana $\mathrm{n}$. sp.

Figures 20.1-20.4, 27.2, 27.5-27.8, 27.12-27.19, 28.1-28.3, 28.7, 29.6, 29.9, 30.7, 31.1, 32.4, 32.5

zoobank.org/0A378AB5-4154-4CA7-B158-A5FCE2BFBD87

1972 Globivalvulina bulloides (Brady); Toomey, p. 295, pl. 2, figs. 19, 20, 21, 22, 23.

v. 1993 Globivalvulina ex gr. bulloides (Brady); Vachard, Oviedo, Flores de Dios, Malpica, Brunner, Guerrero and Buitrón, pl. 6, fig. 8; pl. 8, figs. 7, 8, 9 .

2000 Globivalvulina ex gr. bulloides (Brady); Groves, pl. 2, figs. 25, 26, 27, 28, 29, 30, $31,32$.

v. 2003 Globivalvulina spp. (partim); Krainer, Vachard and Lucas, pl. 8, figs. 1, 11, 15, $16 ?$

v. 2009 Globivalvulina ex gr. mosquensis Reitlinger; Krainer, Lucas and Vachard, pl. 4, figs. 6,7 .

v. 2013b Globivalvulina cf. G. mosquensis Reitlinger; Lucas, Krainer and Voigt, fig. 8G.

v. 2013b Globivalvulina cf. donbassica Potievskaya; Vachard, Krainer and Lucas, p. 348 (no illustration).

Etymology. Latinized name indicating a New Mexican origin.

Holotype. NMMNH P-67561; Figure 25.1; sample MLY 6-17.

Paratypes. NMMNH P-67562, 67563; Figures 21.15, 22.2. 

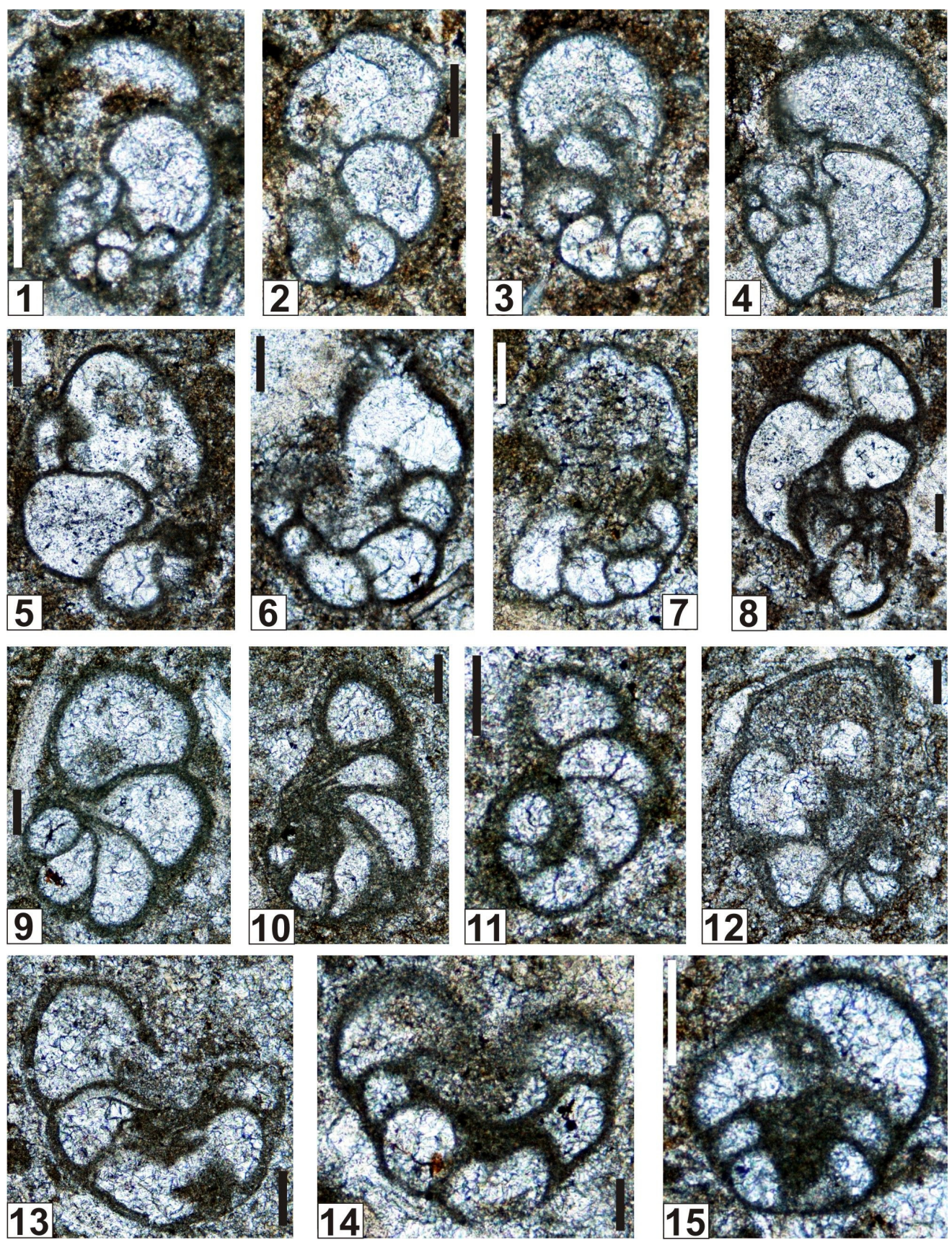

FIGURE 21. 1-8. Globivalvulina retroseptata n. sp. 1. NMMNH P-67554, paratype. Axial section showing the siphon formed by a curved backwards septum and an oral valvula. San Andres Fm. Sample SAR 10-3. 2. NMMNH P-67555, paratype. Transverse section. San Andres Fm. Sample SAR 12-6. 3. NMMNH P-67556, paratype. Subtransverse section. San Andres Fm. Sample SAR 12-7. 4. NMMNH P-67553, holotype. Transverse section. San Andres Fm. Sample SAR 13-2. 5. NMMNH P-67557, paratype. Subtransverse section. San Andres Fm. Sample SAR $13 a-3 a .6$. NMMNH P-67558, paratype. Oblique section. San Andres Fm. Sample SAR 13a-4. 7. NMMNH P-67559, paratype. Subtransverse section. San Andres Fm. Sample SAR 13a-6. 8. NMMNH P-67560, paratype. Oblique subtransverse section. San Andres Fm. Sample SAR 13a-3. 9-14. Globivalvulina praegraeca n. sp. 9. NMMNH P-67565, paratype. Subtransverse section. San Andres Fm. Sample SAR 7-1. 10, NMMNH P-67566, paratype. Subtransverse section. San Andres Fm. Sample SAR 7-2. 11, NMMNH P-67567, paratype. Oblique subtransverse section. San Andres Fm. Sample SAR 7-6. 12. NMMNH P-67564, holotype. Subtransverse section. San Andres Fm. Sample SAR 7-7. 13. NMMNH P-67568, paratype. Subaxial section. San Andres Fm. Sample MLY 3-3. 14. NMMNH P-67569, paratype. Axial section. San Andres Fm. Sample MLY 6-18. 15. Globivalvulina novamexicana n. sp., NMMNH P-67562, paratype. Oblique subaxial section. San Andres Fm. Sample MLY 5-22. Scale bars equal $0.10 \mathrm{~mm}$. 
Material. 70 specimens.

Locus Typicus. NMMNH locality 8899; San Andres Formation, McLeod Hills in the southern Caballo Mountains (New Mexico).

Stratum Typicum. Middle? Kungurian (late Leonardian).

Diagnosis. Test medium-sized, often ovoid, with septa curved backward, funnel wide and shallow, and thin microgranular wall.

Description. Test subspherical to nautiloid, moderate in size $(D=$ (rarely 0.23$)-0.28-0.55 \mathrm{~mm} ; \mathrm{w}=$ (rarely 0.24-0.25)-0.30-0.62 mm; w/D = 0.89-1.20). Slightly trochospiral axis of biseriality. Dorsal side convex. Sutures absent or very weak. Lateral sides strongly convex to a few compressed on the flanks. Proloculus medium to large (0.05-0.06 $\mathrm{mm}$ ), spherical. Whorl: 1-1.5. Peripheral margin round. Lateral sides of spire inflated. Umbilicus absent. Chambers: 6-7 (rarely 8) pairs, subtriangular, and with $\mathrm{h}=$ (rarely $0.07-0.09) 0.11-0.20 \mathrm{~mm}$. Septa almost perpendicular to the wall. Ventral side flattened to slightly depressed. Aperture in basal slit. Oral valvula weakly developed to absent. Wall bilayered, with an inner layer relatively developed, especially on the septa; $\mathrm{s}=0.02-0.04 \mathrm{~mm}$ with a maximum of $0.01 \mathrm{~mm}$ for the inner layer.

Comparisons. This taxon is similar to $G$. donbassica Potievskaya, 1962 but differs by slightly larger dimensions, chambers less rounded in transverse section, and a basal part more planar in axial section. This species also resembles Globivalvulina biserialis Cushman and Waters 1928b sensu St Jean, 1957 (p. 36-37, plate 3, figures 3a-c, 4-5) but differs in the shape of the axial section. It also resembles G. mosquensis Reitlinger, 1950 but differs in its larger dimensions (D, w, h) for the same number of chambers and in the great difference of age (G. mosquensis is initially a Moscovian species). The morphology is relatively similar to that of Globivalvulina bulloides; the main difference is the wall microstructure (a possible but controversial generic character; see Brenckle, 2005; Vachard et al., 2006).

Occurrence. Kungurian (late Leonardian) of New Mexico (Yeso Group, Los Vallos Formation, Torres Member, Massacre Gap in the southern Fra Cristobal Mountains: samples MG(2) 10-1, MG 10-3, MG 10-6, MG 10-6a, MG 10-7, MG 10-8, MG 1014, MG 10-17, MG 10-17a, MG 10-18, MG 10-19a, MG 12-1, MG 12-4; San Andres: samples MLY 3-2, MLY 3-6, MLY 3-7a, MLY 3-8, MLY 3-10, MLY 4-1, MLY 4-2, MLY 4-4, MLY 4-6, MLY 4-9, MLY 4-13, MLY 4-17, MLY(2) 5-2, MLY(2) 5-2a, MLY 5-7c, MLY 5-20a, MLY(2) 5-21, MLY 5-22, MLY(2) 5-23,
MLY 6-1, MLY(2) 6-1, MLY(2) 6-2, MLY 6-16, MLY 6-17, MLY(2) 6-23, MLY(2) 6-25, MLY 6-29a, MLY 8-8, SAR 7-3, SAR(2) 8-4, SAR 8-5, SAR 8a-5a, SAR 8a-9, SAR 8a-12, SAR 8a-20, SAR 8a-21, SAR 8a-24, SAR 12-2, SAR(2) 12-4, SAR(2) 13-3, SAR(2) 13-4, SAR(2) 13-5, SAR(2) 13-8, SAR(2) 13-11, SAR 13-12, SAR(2) 13a-3/3a, SAR 20-8).

Globivalvulina praegraeca n. sp.

Figures 21.9-21.14, 28.4-28.6, 28.8-28.12, 28.1428.16, 29.5, 29.8, 29.10-29.13, 30.1, 30.4-30.6,

$30.8-30.10,30.12,30.14,30.15,31.2-31.8$

zoobank.org/F390F0B9-8701-49DB-A753-F7ECDDC800AB

1970 Globivalvulina graeca Reichel; KochanskyDevidé, p. 185, pl. 9, fig. 6; pl. 18, figs. 1, 2.

1972 Globivalvulina aff. donbassica Potievskaya; Sosipatrova, pl. 10, figs. 14, 15.

1974 Globivalvulina graeca Reichel; Akopian, p. 101, pl. 39, fig. 4.

2009 Globivalvulina syzranica Reitlinger; Blazejowski, fig. 10.3.

2009 Globivalvulina graeca Reichel; Blazejowski, figs. 10.4-5.

2009 Globivalvulina cf. graeca Reichel; Blazejowski, fig. 10.6-9.

v. 2013b Globivalvulina cf. graeca Reichel; Vachard, Krainer and Lucas, p. 348 (no illustration).

Etymology. Probable ancestor of G. graeca Reichel, 1946.

Holotype. NMMNH P- 67564; Figure 21.12; sample SAR 7-7.

Paratypes. NMMNH P- 67565-67569; Figure 21.911, 21.13-14.

Material. 40 specimens.

Locus Typicus. NMMNH locality 8900; San Andres Formation, reference section in the San Andres Mountains (New Mexico).

Stratum Typicum. Late? Kungurian (latest Leonardian).

Diagnosis. Test large, with a wide aperture, a deep and relatively wide funnel, no oral valvula, and a bilayered wall, but with an inner pseudofibrous layer that is very thin and discontinuous.

Description. Test nautiloid, involute, and large: D $=(0.45)-0.50-0.73-(0.83) \mathrm{mm}, \mathrm{w}=0.50-0.72 \mathrm{~mm}$, $\mathrm{w} / \mathrm{D}=0.71-1.0$. Planispirally coiled axis of biseriality. Proloculus spherical, small $(0.02)$ to large (0.06-0.13 mm), and subprominent. Dorsal side convex, curved to semicircular. Sutures weak to absent. Whorls: 1-1.5. Peripheral margin rounded to slightly angular; lateral sides of spire slightly 


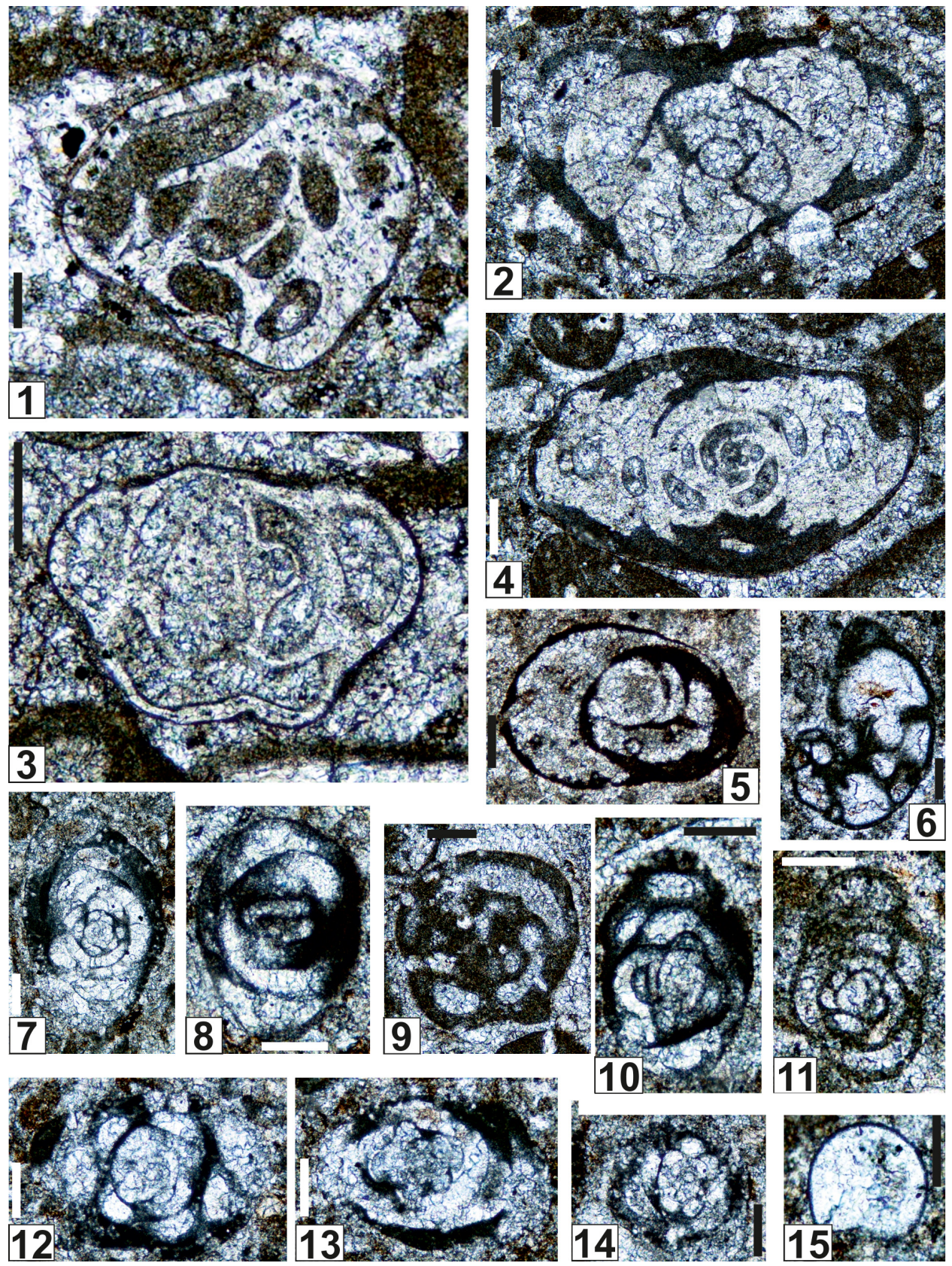

FIGURE 22. 1, 3. Glomomidiella infrapermica n. sp. 1. NMMNH P-67600, holotype. Subtransverse section. Yeso Group. Sample MG 10-22. 3. NMMNH P-67601, paratype. Subtransverse section. Yeso Group. Sample MG 10-25. 2. Orthovertellopsis proteaeformis n. gen. n. sp., NMMNH P-67570, holotype. Axial section with relatively well-preserved wall. Yeso Group. Sample MG 10-21. 4, 7-8, 10, 12-14. Praeneodiscus convexus n. gen. n. sp. 4. NMMNH P-67606, holotype. Axial section. Yeso Group. Sample MG 10-24. 7. NMMNH P-67607, paratype. Axial section. San Andres Fm. Sample MLY 5-13 (already illustrated in Brose et al., 2013, figure 6. 11). 8. NMMNH P-67608, paratype. Axial section. San Andres Fm. Sample MLY 5-4. 10. NMMNH P-67609, paratype. Axial section with a relatively preserved wall. San Andres Fm. Sample MLY 5-7. 12. NMMNH P-67610, paratype. Axial section. San Andres Fm. Sample MLY 5-7a. 13. NMMNH P-67611, paratype. Axial section. San Andres Fm. Sample MLY 5-30. 14. NMMNH P-67612, paratype. Axial section. San Andres Fm. Sample MLY 5-21. 5. Tubiphytes epimonellaeformis n.sp. Subtransverse section. San Andres Fm. Sample SAR 8a-22. 6. Globivalvulina parapiciformis n. sp. NMMNH P-67551, holotype. Transverse section. San Andres Fm. Sample MLY 4-3. 9. Pseudospira aff. ishimbaica (Lipina, 1949). Subtransverse section. Yeso Group. Sample MG 10-26. 11. Hemigordiellina? cf. simplex (Harlton, 1928). Axial section. San Andres Fm. Sample MLY 6-28. 15. Eotuberitina reitlingerae Miklukho-Maklay, 1958. Axial section. San Andres Fm. Sample MLY 4-5. Scale bars equal $0.10 \mathrm{~mm}$. 
inflated; umbilicus absent. Chambers rectangular; the last one is rounded trapezoidal; $n=5-7$ (rarely 8 ); $\mathrm{h}=$ (rarely 0.13-0.20)-0.20-0.43 mm. Septa regular, sigmoid, typical of the genus. Ventral side concave to flattened. Aperture broad with a deep and relatively wide funnel. Oral valvula not obvious. Wall bilayered ( $\mathrm{s}=0.03-0.05 \mathrm{~mm}$ ) and relatively thick, microgranular with calcareous agglutinate, locally bilayered with an inner pseudofibrous clear layer that is very thin and not obviously continuous.

Comparisons. The new species differs from $G$. graeca by smaller dimensions (mean diameter of G. graeca $=0.70 \mathrm{~mm}$ ), less chambers, wider aperture and less developed funnel, larger proloculus, absence of lamella, and thinner and discontinuously located inner pseudofibrous layer. It differs from G. syzranica Reitlinger, 1950 by the shape of the chambers and the deeper funnel; from $G$. donbassica Potievskaya, 1962 by larger dimensions (in this latter species, $\mathrm{D}=0.31-0.42 \mathrm{~mm}$; $\mathrm{w}=0.26$ $0.39 \mathrm{~mm}$ ), and higher chambers (maximum 0.22 $\mathrm{mm}$, mainly $0.11-0.15 \mathrm{~mm}$ in $\mathrm{G}$. donbassica), and from G. granulosa Reitlinger, 1950 by the stronger development of the pseudofibrous inner layer, less thick wall (up to $0.06 \mathrm{~mm}$-thick in G. granulosa), less coarse calcareous agglutinate, and the deep funnel. Furthermore, contrary to Pinard and Mamet (1998), we do not assign G. granulosa to the group $G$. bulloides, because of the difference of wall microstructure.

Occurrence. Early Permian of Croatia and Armenia. Early Artinskian of Spitsbergen. Middle?-late? Kungurian (late Leonardian) of New Mexico (San Andres Formation, McLeod Hills (MLY) and reference section in the San Andres Mountains (SAR): samples MLY 3-3, MLY(2) 4-9, MLY 6-18, samples SAR 3-4, SAR 7-1, SAR 7-2, SAR 7-4, SAR 7-5, SAR 7-6, SAR 7-7, SAR 8-1, SAR(2) 8-1a, SAR 82, SAR(2) 8-3, SAR(2) 8-4, SAR(2) 8-6, SAR 8-7, SAR 8-7a, SAR(2) 8-8, SAR(2) 8-10, SAR(2) 8-18, SAR(2) 8-21, SAR 8a-2, SAR 8a-5, SAR 8a-10, SAR 8a-10a, SAR 8a-12, SAR 8a-13a, SAR 8a-20, SAR 8a-21, SAR 8a-24, SAR 9-1, SAR 12-7, SAR 13-1, SAR(2) 13-2, SAR(2) 13-6, SAR(2) 13-9, $\operatorname{SAR}(2)$ 13a-4).

Class MILIOLATA Lankester, 1885 nom. translat. Saidova, 1981

Order MILIOLIDA Lankester, 1885

Remarks. The principal character of the class Miliolata is the porcelaneous wall. This wall, composed of high magnesian calcite, is often unstable, and the typical extant aspect amber-coloured or tan-skinned (Scholle and Ulmer-Scholle, 2003, p.
41) becomes rapidly and eodiagenetically black, and then, whitish if it is meso- or telodiagenetized in neosparite and/or silica and/or anhydrite (Vachard et al., 2005, plate. 4, figures 1, 2, 3, 4, 5, $6,7,8,9,10,11,12,13,14,15,16,17)$.

When the wall is black, it is strictly identical in optical as well as in electronic microscopy to the originally microgranular wall of a Fusulinata. For instance, our unpublished material of Palaeozoic Miliolata, SEM-observed, is similar in wall aspect to the Fusulinida Eostaffella illustrated by Vachard et al. (2004, plate 1, figure 2). The argument of Pronina (1994) that "Late Permian cornuspirids [which] have microgranular wall structure (...) are considered to belong to genus Pseudoammodiscus" is therefore irrelevant.

Because it is originally purely calcitic, a microgranular wall remains more stable than a porcelaneous one. Consequently, the difference between some taxa of Miliolata and Fusulinata are not purely dialectic and diagenetic, and cannot be indicated only by arguments of formal logic. That is particularly true for the genus Cornuspira Schultze, 1854 in opposition to the genus Pseudoammodiscus Conil and Lys in Conil and Pirlet, 1970; as well as Hemigordiellina Marie in Deleau and Marie, 1961 sensu Vachard and Beckary, 1991 versus "Pseudoglomospira" auctorum (non Bykova in Bykova and Polenova, 1955) or Pseudospira Reitlinger in Vdovenko et al., 1993; or Hoyenella Rettori, 1994 emend. Gaillot and Vachard, 2007 versus Glomospirella Plummer, 1945 auctorum; Brunsiella Reitlinger, 1950 versus Brunsia Mikhailov, 1935; Palaeonubecularia Reitlinger, 1950 versus Tolypammina Rhumbler, 1895, etc. Despite the homeomorphy existing between the free bilocular Late Mississippian (Serpukhovian) Pseudoammodiscus and Cornuspira (underlined for example by Tappan and Loeblich, 1988), Gaillot and Vachard (2007) supposed that the phylogenetic change from a microgranular to a porcelaneous wall occurred in a group of attached forms because of: 1) the older appearance of these porcelaneous forms (at the beginning of the Serpukhovian; whereas the FAD of Cornuspira would be late Serpukhovian in age); 2) the great morphological similarity between attached genera like Scalebrina Conil and Longerstaey in Conil et al., 1980 and Palaeonubecularia; 3) the dominance of the attached porcelaneous forms during the Bashkirian; 4) the rarity of Cornuspira and Hemigordiellina during the Bashkirian-Moscovian; 5) the FAD of the first genus universally accepted as porcel- 

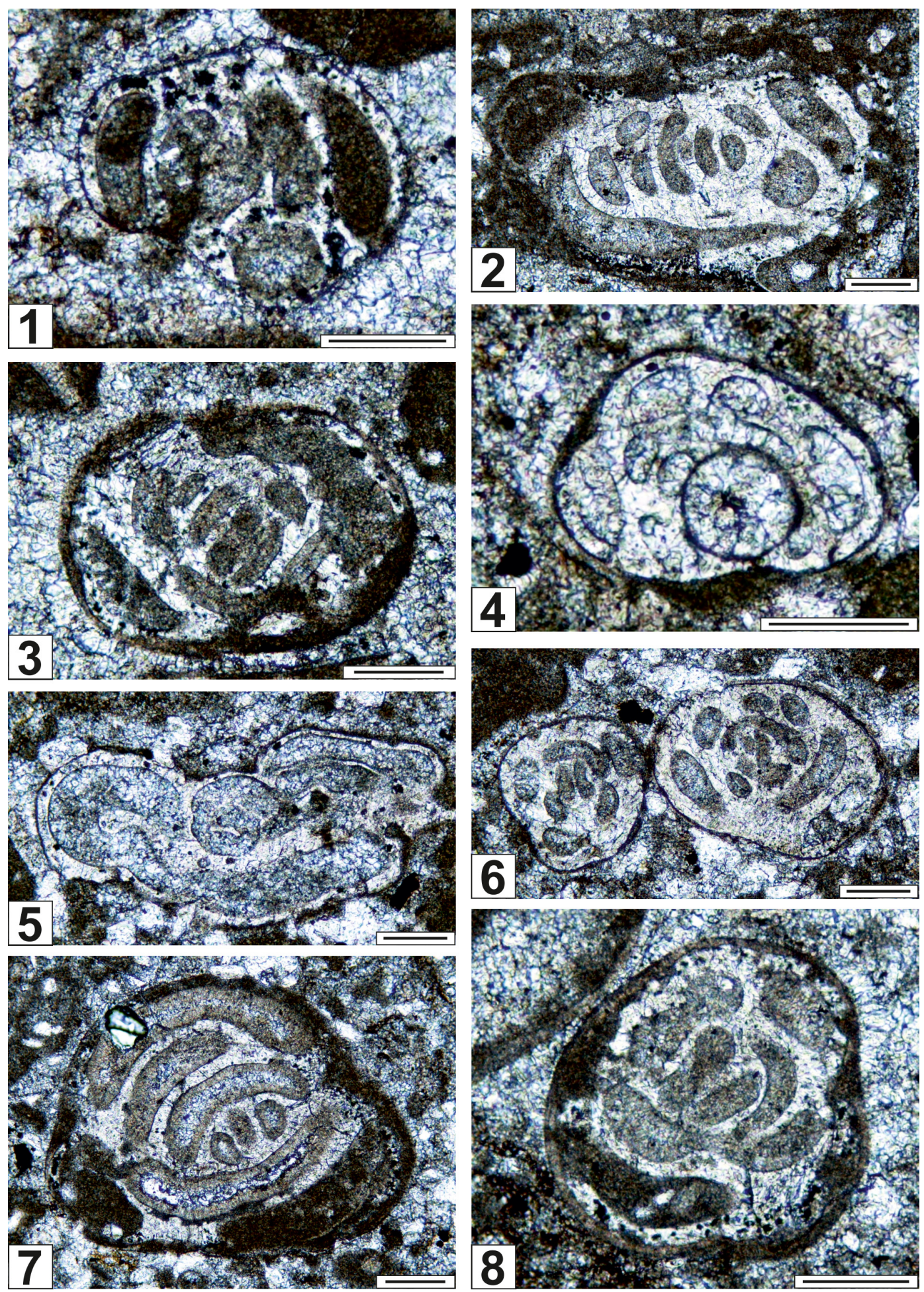

FIGURE 23. 1, 3, 7-8. Glomomidiella infrapermica n. sp. 1. NMMNH P-67602, paratype. Subtransverse section. Yeso Group. Sample MG 10-12. 3. NMMNH P-67603, paratype. Oblique subaxial section. Yeso Group. Sample MG 10-15. 7. NMMNH P-67604, paratype. Two subtransverse sections. Yeso Group. Sample MG 10-2. 8. NMMNH P-67605, paratype. Subtransverse section. Yeso Group. Sample MG 10-16. 2, 4, 6. Orthovertellopsis proteaeformis n. gen. $\mathrm{n}$. sp. 2. NMMNH P-67571, paratype. Subaxial section. Yeso Group. Sample MG 10-23. 4. NMMNH P-67572, paratype. Subaxial section. Yeso Group. Sample MG 10-13a. 6. NMMNH P-67573, two paratypes. Subtransverse section. Yeso Group. Sample MG 10-20. 5. Calcitornella cf. elongata Cushman and Waters, 1928a. Subaxial section. Yeso Group. Sample MG 10-20a. Scale bars equal $0.10 \mathrm{~mm}$. 
aneous, i.e., Hemigordius Schubert, 1908, is during the late Moscovian.

Superfamily ?NUBECULARIOIDEA Jones in Griffith and Henfrey, 1875 nom. translat. Mikhalevich, 1988

Family ?CALCIVERTELLIDAE Loeblich and Tappan, 1964 nom. translat. Reitlinger in Vdovenko, Rauzer-Chernousova, Reitlinger and Sabirov, 1993 emend. Gaillot and Vachard, 2007

Description. Attached bilocular, undivided, tubular genera separated by the type of coiling and/or the thickness of the wall. Porcelaneous wall often neosparitized. Aperture terminal, simple.

Occurrence. Serpukhovian-Recent, cosmopolitan.

\section{Genus AMMOVERTELLA Cushman, 1928}

Type Species. Psammophis inversus Schellwien, 1898.

Description. Calcivertellid characterised by a zigzagging initial coiled stage followed by an erect last stage.

Remarks. For Henbest (1963), Ammovertella is the Textulariata homeomorph of the Miliolata $\mathrm{Cal}$ civertella Cushman and Waters, 1928a. Inversely, Vachard and Krainer, (2001a, p. 157) have indicated that Ammovertella has a porcelaneous wall and not an agglutinated wall and consequently belongs to the family Calcivertellidae and not to the Ammodiscidae. According to Gaillot and Vachard (2007), a part of the atypical species of this genus belongs to Calcivertella or Palaeonubecularia.

We suggest here that Calcivertella, Ammovertella, and Trepeilopsis Cushman and Waters, 1928a are related but distinct genera due to their microhabitats and types of attachment. If the three genera are synonymous, Calcivertella has priority to designate the taxon.

Occurrence. Pennsylvanian-Permian, cosmopolitan.

\section{Ammovertella sp.}

Figure 34.13

? 1984 "Ammodiscella" sp.; Flügel, KochanskyDevidé and Ramovs, pl. 32, fig. 2.

v. 2013b Ammovertella sp.; Vachard, Krainer and Lucas, p. 348 (no illustration).

Description. Planispiral initial stage followed by an uncoiled tubular last part. $D=0.26 \mathrm{~mm}$; whorls: 4 ; $\mathrm{p}=0.05 \mathrm{~mm} ; \mathrm{h}=0.04 \mathrm{~mm} ; \mathrm{s}=0.01 \mathrm{~mm}$. Proloculus spherical, moderately large, larger than the first whorl, with a short flexostyle channel. No umbilicus. Four whorls. Lateral sides of spire slightly inflated. Peripheral margin rounded. Uncoiling in the form of a tubular chamber in which the diameter is equal to the height of the last planispiral whorl, erect, vertical, tubular, perpendicular with the axis of coiling. No secondary incrustation of lateral walls. Wall porcelaneous, dark transformed in microgranular calcite.

Occurrence. Late? Kungurian (latest Leonardian) of New Mexico (San Andres Fm; sample SAR 139a).

Genus PALAEONUBECULARIA Reitlinger, 1950

Type Species. Palaeonubecularia rustica Reitlinger, 1950.

Description. Attached, uncoiled tubular, serpentiform, gregarious test. Proloculus and early stage poorly known. Wall porcelaneous, often transformed in microgranular calcite or poorly silicified (and consequently, they are often misinterpreted as Fusulinata pseudolituotubids and Textulariata tolypamminids).

Remarks. The gregarious tubes of this genus are generally few around the substrate; nevertheless, some reefs of Palaeonubecularia have been described, in particular in the Artinskian of the PreUrals, Russia (Khvorova, 1951).

Occurrence. Late Mississippian (Serpukhovian)Late Permian (Wuchiapingian), cosmopolitan.

Palaeonubecularia sp.

Figures 13.2, 20.14, 33.25, 34.7, 34.8

v. 2013b Palaeonubecularia sp.; Vachard, Krainer and Lucas, p. 348 (no illustration).

Description. No initial glomospiral stage known; the tube is immediately serpentiform. Sutures absent but tube limits very visible. Whorls relatively numerous but difficult to estimate exactly. Lateral sides of spire inflated. Peripheral margin round. Aperture not observed. $\mathrm{L}=1.25-2.50 \mathrm{~mm} ; \mathrm{H}=$ $0.68-0.75 \mathrm{~mm} ; \mathrm{h}=0.08-0.25 \mathrm{~mm} ; \mathrm{s}=0.03 / 0.05$ $\mathrm{mm}$.

Remark. Similar in its dimensions to $P$. rustica, this taxon differs by the thinner wall and the less elongate lumen.

Occurrence. Early?-late? Kungurian (Leonardian) of New Mexico (Yeso Group: samples MG 10-26a, MG 10-28, MG 10-29, MG 10-5, MG 12 7a, MG(2) 12 10. San Andres Fm: samples MLY(2) 5-19, MLY(2) 5-22, MLY 5-29, MLY 6-24, SAR 20).

Genus CALCITORNELLA Cushman and Waters, 1928a

Type Species. Calcitornella elongata Cushman and Waters, 1928a. 

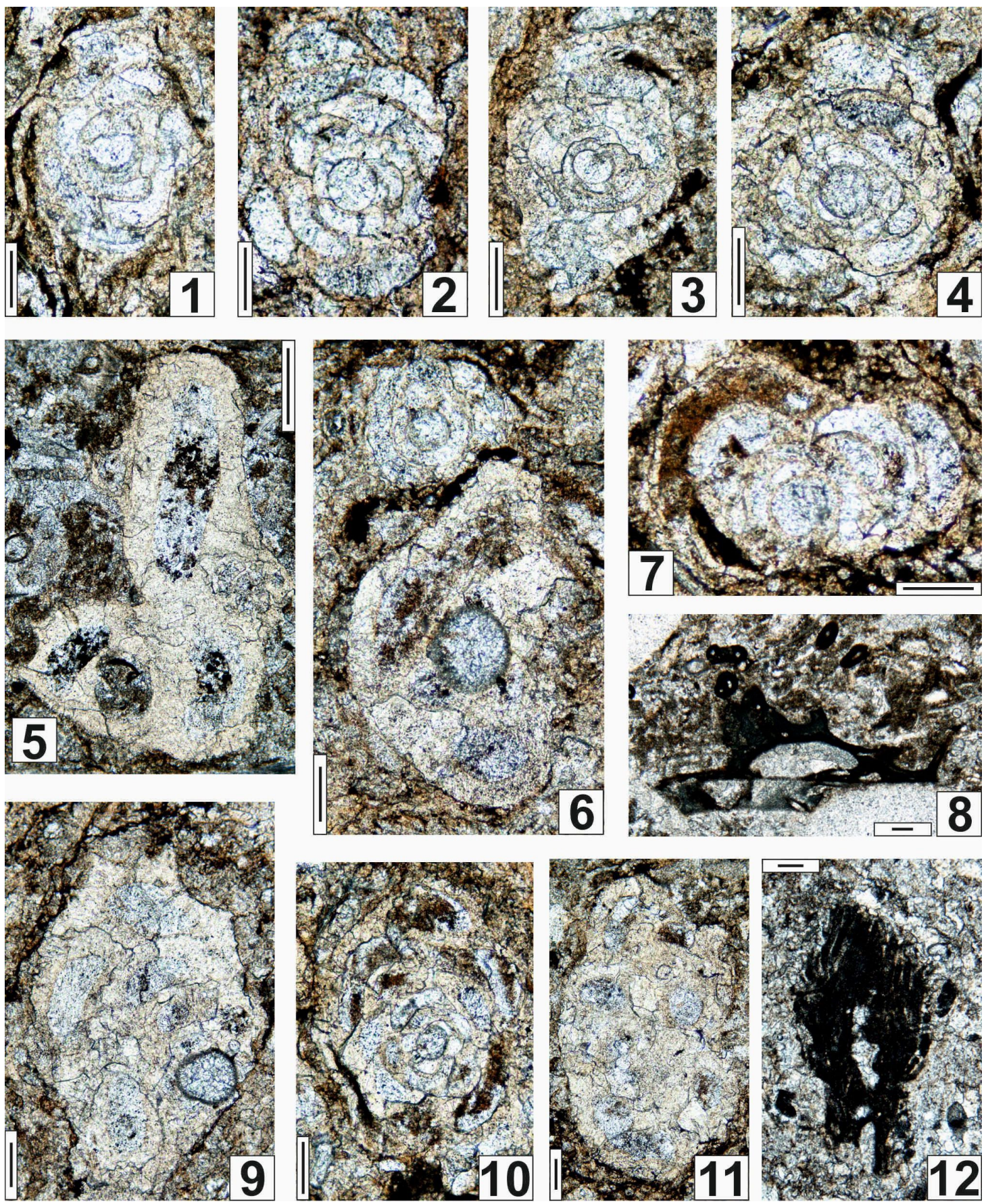

FIGURE 24. 1-4, 7, 10. Olgaorlovella davydovi n. gen. n. sp. 1. NMMNH P-67595, paratype. Axial section. San Andres Fm. Sample SAR 11-15. 2. NMMNH P-67596, paratype. Axial section. San Andres Fm. Sample SAR $11 a-7$. 3. NMMNH P-67597, paratype. Axial section. San Andres Fm. Sample SAR 11-8. 4. NMMNH P-67598, paratype. Axial section. San Andres Fm. Sample SAR 11-12. 7. NMMNH P-67599, paratype. Subaxial section. San Andres Fm. Sample SAR 11-6b. 10. NMMNH P-67594, holotype. Axial section. San Andres Fm. Sample SAR 11-2. 5-6, 9, 11. Orthovertellopsis calcitornellaeformis $n$. gen. $n$. sp. 5. NMMNH P-67575, paratype. Oblique section showing the costae. San Andres Fm. Sample SAR 12-8. 6. NMMNH P-67574, holotype. Transverse section with Olgaorlovella davydovi n. gen. n. sp. San Andres Fm. Sample SAR 11-10. 9. NMMNH P-67592, paratype. Oblique section. San Andres Fm. Sample SAR 11a-13. 11. NMMNH P-67593, paratype. Subaxial section. San Andres Fm. Sample SAR 11-7a. 8, 12. Tubiphytes epimonellaeformis n. sp. 8. Subaxial section. San Andres Fm. Sample SAR 12-1. 12. Subaxial section difficult to distinguish from T. obscurus Maslov, 1956. San Andres Fm. Sample SAR 3-3. Scale bars equal $0.10 \mathrm{~mm}$. 
Description. Calcivertellid characterised by a nearly planispirally coiled initial stage followed by a serpentiform last stage.

Remarks. According to Henbest (1963), Apterinella Cushman and Waters, 1928b and Calcitornella are two synonyms among the Miliolata. However, Calcitornella is prioritary over Apterinella, because these genera have been described on $p$. 45-47 and p. 64, respectively, of the same publication. On the other hand, Apterinella was too poorly defined to be preferred to Calcitornella. That was first suggested by Browne and Pohl (1973), even if these latter authors have erroneously considered Calcitornella as a representative of the Fusulinata Pseudoammodiscidae.

Occurrence. Pennsylvanian-Permian; cosmopolitan.

Calcitornella cf. elongata Cushman and Waters, $1928 \mathrm{a}$

Figures 23.5, 34.19

? 1928a Calcitornella elongata Cushman and Waters, p. 47-48, pl. 6, fig. 5.

? 1985 Calcitornella elongata Cushman and Waters; Palmieri in Foster, Palmieri and Fleming., p. 80, pl. 5, figs. 11, 12, 13.

v. 2013b Calcitornella cf. elongata Cushman and Waters; Vachard, Krainer and Lucas, p. 348 (no illustration).

Description. Poorly developed glomospiral initial stage followed by an uncoiled tubular last part arranged symetrically around the initial coiling ( $D=$ $0.67 \mathrm{~mm} ; \mathrm{w}=0.29 \mathrm{~mm}$ ). No umbilicus. Four whorls. Lateral sides of spire flat to slightly inflated. Peripheral margin rounded. Uncoiling in form of a tubular chamber in which the diameter is equal to the height of the last planispiral whorl ( $h=0.10$ $\mathrm{mm}$ ), erect, vertical, tubular, aligned with the axis of coiling. No secondary incrustation of lateral walls. Wall originally porcelaneous, currently neosparitized $(\mathrm{s}=0.01 \mathrm{~mm})$.

Occurrence. Late Pennsylvanian of Texas and Ecuador. Early Permian of Australia. Middle Permian of Cambodia. Early?-middle? Kungurian of New Mexico (Yeso Group: sample MG 10-20a. San Andres Fm: sample MLY(2) 5a-24).

Genus ORTHOVERTELLOPSIS n. gen.

zoobank.org/DA607E3F-F49B-47CC-A605-E821FC00F3ED

Etymology. Similar to Orthovertella Cushman and Waters, 1928a.

Synonym. Orthovertella (pars).

Type Species. Orthovertellopsis proteaeformis n. gen. n. sp.
Diagnosis. Free Calcivertellidae? characterised by a large coiled initial coiled stage followed by a very short uncoiled, rectilinear last stage.

Composition. Orthovertellopsis proteaeformis $\mathrm{n}$. gen. n. sp.; O. calcitornellaeformis n. gen. n. sp.; Orthovertella? simplicissima Miklukho-Maklay, 1968; Midiella glomospiroidalis (Sosipatrova, 1972) sensu Blazejowski, 2009, figure 16.12; Hemigordius hyrnefjelleti Blazejowski, 2009; $H$. sp. sensu Blazejowski, 2009, figures 15.8-12, 16.1314; H.? sp. sensu Blazejowski, 2009, figure 15.7; Hemigordiopsida indet. sensu Blazejowski, 2009, figure 15.13-15; Orthovertella protea sensu Crespin, 1958; O. protea sensu Foster, Palmieri and Fleming, 1985, ?Orthovertella sp. 1 sensu Lambert et al. (2002, plate 7, figure 28); ?Graecodiscus praecursor Nestell and Nestell, 2006; and ?G. sp. 2 sensu Nestell and Nestell, 2006.

Comparison. Orthovertellopsis n. gen. differs from Orthovertella by a terminal stage less developed, a more regular coiling, and differs from Calcitornella by a more regular coiling and a free habitat indicated by the absence of an attachment plane face.

Occurrence. Kungurian (late Leonardian) of New Mexico. Early Permian of Australia (Carnarvon Basin, Canning Basin, Tasmania, and perhaps Sydney Basin). Permian of South China. Early Kazanian (Middle Permian) of the Urals. ?Latest Guadalupian of Texas.

Orthovertellopsis proteaeformis n. gen. n. sp.

Figures 22.2, 23.2, 23.4, 23.6, 33.19, 33.20, 35.10, 35.12

zoobank.org/47A263E8-C536-4705-B36C-7CEF5B7CA43D

? 1958 Orthovertella protea Cushman and Waters; Crespin, p. 82, pl. 18, figs. 7-9.

1985 Orthovertella protea Cushman and Waters; Foster, Palmieri and Fleming, p. 81, pl. 5, figs. 5-7.

? 1993 Neodiscus cf. permicus (Grozdilova); Ueno and Sakagami, fig. 3.14.

? 2006 Hemigordius sp. 1; Nestell, Nestell, Wardlaw and Sweatt, pl. 1, fig. 21 (only).

v. 2013b Orthovertella? sp. 1 (part.); Vachard, Krainer and Lucas, p. 348 (no illustration).

v. 2013b Orthovertella? sp. 2; Vachard, Krainer and Lucas, p. 348 (no illustration).

Etymology. Similar to some O. protea Cushman and Waters, 1928a of the authors.

Holotype. NMMNH P-67570; Figure 22.2; sample MG 10-21.

Paratypes. NMMNH P-67571-67573; Figure 23.2, 23.4, 23.6.

Material. 10 specimens. 

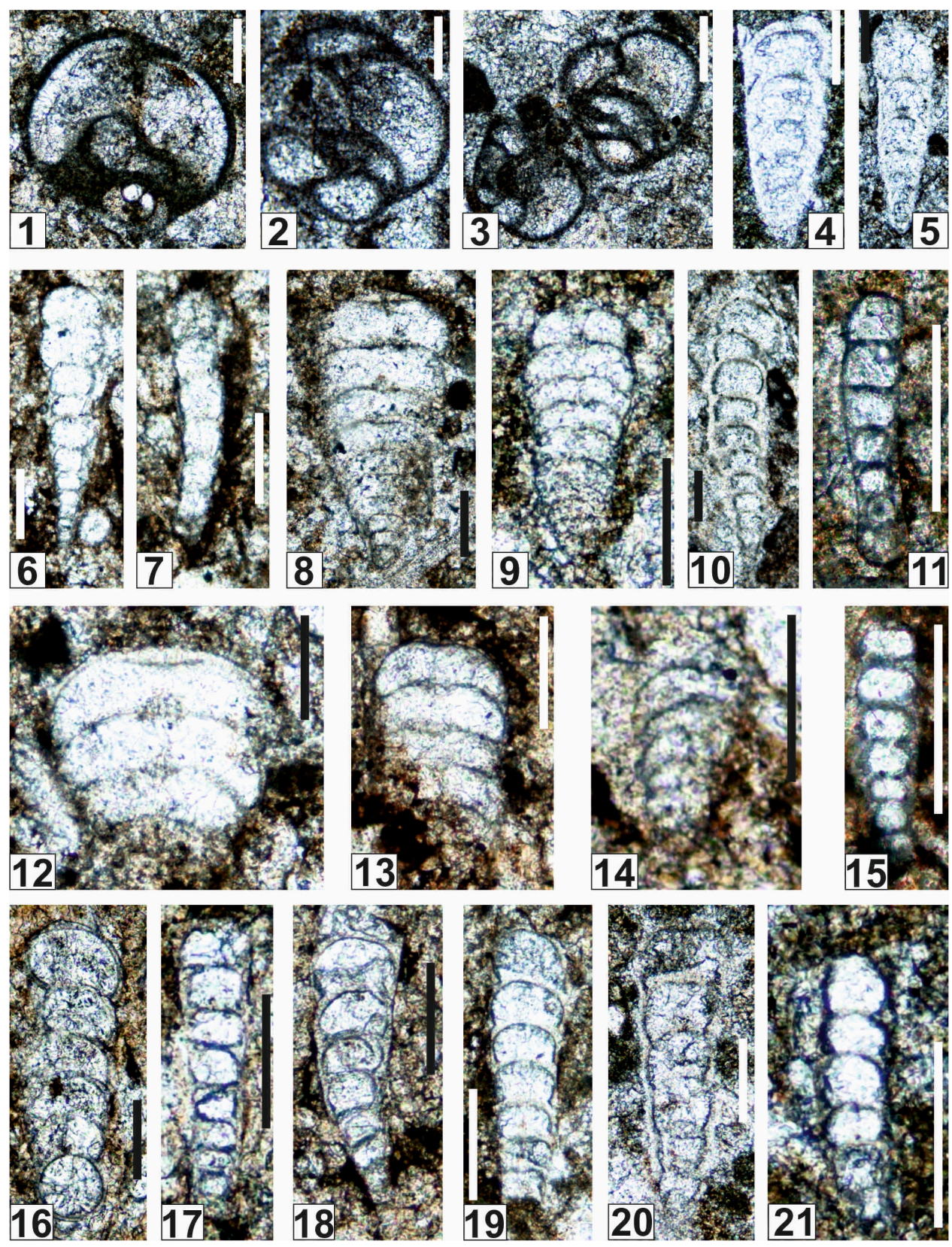

FIGURE 25. 1-2. Globivalvulina novamexicana n. sp. 1. NMMNH P-67561, holotype. Subaxial section. San Andres Fm. Sample MLY 6-17. 2. NMMNH P-67563, paratype. Subaxial section. San Andres Fm. Sample MLY 6-29a. 3. Globivalvulina parapiciformis $\mathrm{n}$. sp. NMMNH P-67552, two paratypes. Two oblique sections. San Andres Fm. Sample MLY 6-11a. 4. Nestellorella? sp. Subaxial section. San Andres Fm. Sample MLY 1-1. 5. Protonodosaria? sp. Subaxial section. San Andres Fm. Sample MLY 3-5. 6-7, 10, 17-19. Nodosinelloides longa (Lipina, 1949). 6. Axial section. San Andres Fm. Sample SAR 8a-4a. 7. Subaxial section. San Andres Fm. Sample SAR 8a-8. 10. Axial section. San Andres Fm. Sample SAR 8a-17 (already illustrated by Brose et al., 2013, figure 6.5). 17. Axial section. San Andres Fm. Sample SAR 11a-6. 18. Axial section. San Andres Fm. Sample SAR 11a-9. 19. Axial section. San Andres Fm. Sample SAR 12-4. 8-9, 12-14. Geinitzina indepressa Cherdyntsev, 1914. 8. Axial section. San Andres Fm. Sample SAR 8a-11. 9. Axial section. San Andres Fm. Sample SAR 8a-14. 12. Subaxial section. San Andres Fm. Sample SAR 8a-7. 13. Subaxial section. San Andres Fm. Sample SAR 11-13. 14. Oblique subaxial section. San Andres Fm. Sample SAR 11a-10. 11, 15, 20?, 21. Nodosinelloides netjaschewi (Cherdyntsev, 1914). 11. Axial section. San Andres Fm. Sample SAR 11-17. 15. Axial section. San Andres Fm. Sample SAR 11-19/19a. 20. Axial section. San Andres Fm. Sample SAR 20.2. 21. Axial section. San Andres Fm. Sample SAR 13a-2. 16. Nodosariata indet. cf. Dentalina cf. ninae Grozdilova sensu Chuvashov et al., 1990. Axial section. San Andres Fm. Sample SAR 11a-4. Scale bars equal $0.10 \mathrm{~mm}$. 
Locus Typicus. NMMNH locality 8901; Yeso Group, Los Vallos Formation, Torres Member, Massacre Gap in the southern Fra Cristobal Mountains (New Mexico).

Stratum Typicum. Early? Kungurian (late Leonardian).

Diagnosis. Large and elongate species of Orthovertellopsis with a large or huge proloculus and a test, inflated in the central part, entirely streptospiral or with the last or semi-last whorl semi-evolute. Wall relatively thick and lumen approximately three times wider than the wall.

Description. The test is large and elongate; $D=$ $0.60-0.85 \mathrm{~mm} ; \mathrm{w}=($ rarely 0.20$)-0.34-0.41 \mathrm{~mm} ; \mathrm{w} /$ $\mathrm{D}=$ (rarely $0.33-0.41)-0.51-0.58$. The spherical proloculus is large to huge (up to $0.09 \mathrm{~mm}$ ). The coiling, initially weakly streptospiral, becomes oscillating and forms a thin-walled glomus, and is then sigmoidal with all the whorls thick-walled, evolute, and with deep sutures. Asymmetrical umbilici are present. Whorls: 4-5-(6), involute at the beginning, then semi-involute and finally evolute. Sutures marked between the different whorls of coiling. Lateral sides of spire irregular. Peripheral margin round. Tube walls relatively thick $(0.02-0.03$ $\mathrm{mm})$. Lumina semi-circular $(\mathrm{h}=0.09-0.13 \mathrm{~mm}$ ). Uncoiling inconspicuous. Some basal lateral thickennings in the wall are obvious.

Remarks. Our sections are very similar to those of Foster et al. (1985) due to the evolute last whorls and the deep sutures that evoke the concavoangulatus stage of the archaediscoids (Pille et al., 2007; Pille, 2008). The uncoiled last stage of coiling is inconspicuous in our thin sections. The new species differs from $O$. protea sensu stricto by the regular elongate test, larger dimensions, less conspicuous uncoiled last part, and different ages (early Late Carboniferous against late Early Permian). It differs from $O$. protea sensu Crespin, 1958 or Foster et al., 1985 by the elongate test and smaller dimensions.

Occurrence. Early Permian Australia (Carnarvon Basin, Canning Basin, Tasmania, and perhaps Sydney Basin). Early?-middle? Kungurian (Leonardian) of New Mexico (Yeso Group, Los Vallos Formation, Torres Member: samples MG(2) 10-6, MG 10-13a, MG(2) 10-14, MG 10-20, MG 10-21, MG 10-23. San Andres Formation, McLeod Hills: samples MLY 6-5, MLY 6-5a). ?Early Murgabian (= Rodian) of NE Thailand.

Orthovertellopsis calcitornellaeformis n. gen. n. sp. Figures 24.5, 24.6, 24.9, 24.11, 34.6, 34.10, 34.17, $35.6,35.7,35.13$

zoobank.org/C5D1A3E1-902B-466E-B8EF-E648998A901E v. 2013b Calcitornella? sp. 1; Vachard, Krainer and Lucas, p. 348 (no illustration).

Etymology. Similar to Calcitornella Cushman and Waters, 1928a.

Holotype. NMMNH P-67574; Figure 24.6; sample SAR 11-10.

Paratypes. NMMNH P-67576, 67592-67593; Figure 24.5, 24.9, 24.11.

Material. 15 specimens.

Locus Typicus. NMMNH locality 8902; San Andres Formation reference section in the San Andres Mountains near Rhodes Canyon (New Mexico).

Stratum Typicum. Late? Kungurian (latest Leonardian).

Diagnosis. Attached porcelaneous, undivided, tubular, thick walled, with internal surface smooth and external surface displaying some acute costae (i.e., apparently transitional between the genera Calcitornella and Hedraites Henbest, 1963).

Description. No transverse growth lines but some small, narrow, equilateral costae are sparsely arranged. The irregular initial spiral is followed by an uncoiled tubular last part. Umbilicus not observed. Sutures relatively well marked. Whorls partially involute in some specimens. Lateral sides of spire flat to slightly inflated. Peripheral margin round to slightly angular. Chamber walls relatively thick. Uncoiling in form of a tubular chamber that has a diameter equal to the height of the last planispiral whorl, erected, vertical, tubular, and perpendicular to the axis of coiling. Measurements: D $=($ rarely $0.35-0.40)-0.52-1.00 \mathrm{~mm} ; \mathrm{w}=$ (rarely 0.15)-0.34-0.66 mm; $p=0.08-0.17 \mathrm{~mm}$; whorls: $1-3$ (rarely 4$) ; \mathrm{h}=0.06-017 \mathrm{~mm} ; \mathrm{s}=0.02-0.04$ - $($ rarely $0.06) \mathrm{mm}$.

Remark. This new species differs from O. proteaeformis n. gen. n. sp. by a more irregular test, some costae and thicker walls.

Occurrence. Middle?-late? Kungurian (late Leonardian) of New Mexico (San Andres Formation, McLeod Hills (MLY) and reference section in the San Andres Mountains (SAR): samples MLY 8-6, SAR 11-7a, SAR(2) 11-10, SAR(2)11-11, SAR 1116, SAR 11a-5, SAR 11a-12a, SAR 11a-13, SAR 11a-16, SAR 12-8, SAR 19-1).

\section{Superfamily CORNUSPIROIDEA Schulze 1854} nom. translat. Mikhalevich, 1988

Family CORNUSPIRIDAE Schulze, 1854

Genus HEMIGORDIELLINA Marie in Deleau and Marie, 1961 emend. Vachard in Vachard and Beckary, 1991

Type Species. Glomospira diversa Cushman and Waters, 1930. 

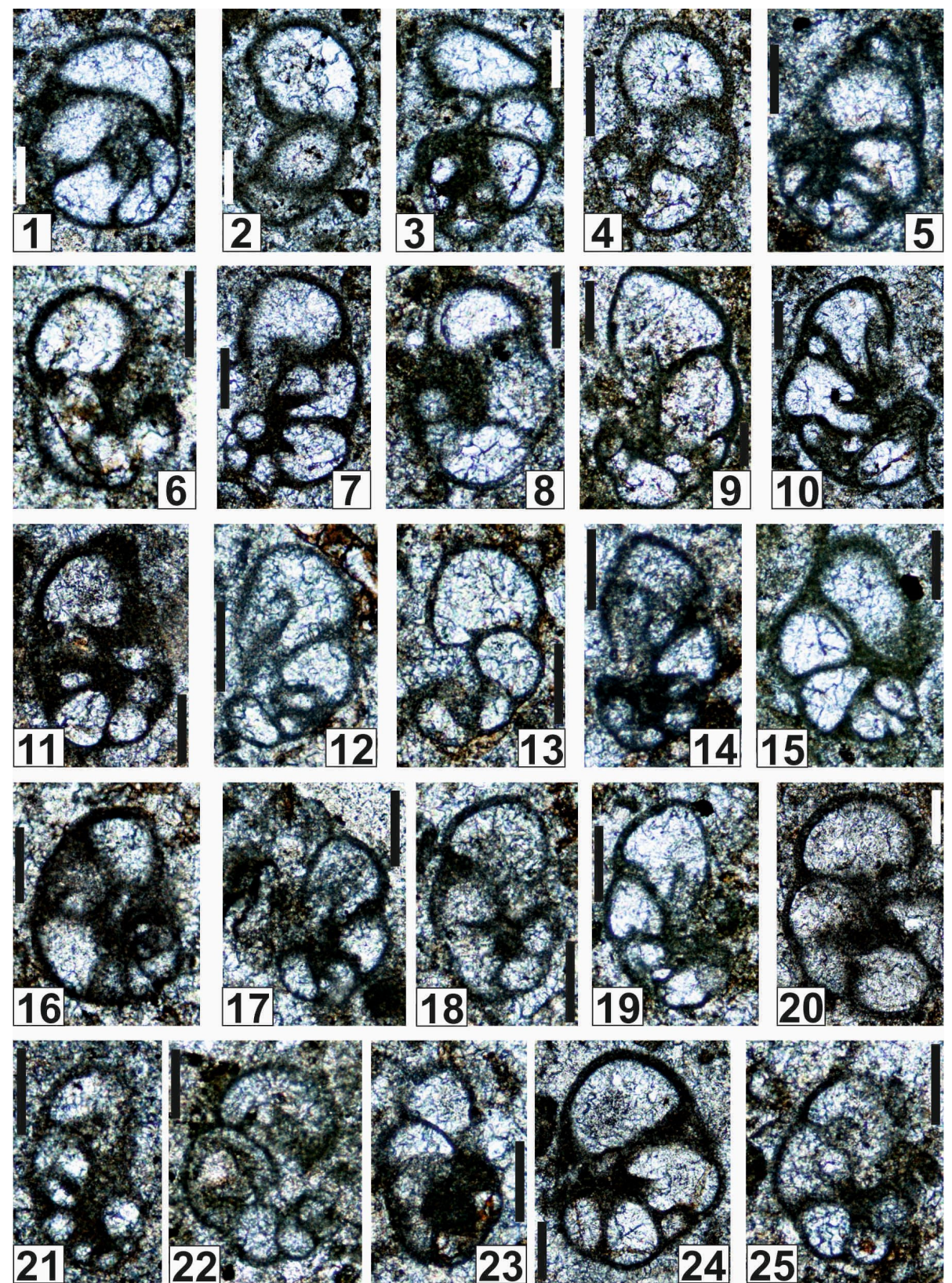

FIGURE 26. 1, 4-7, 9, 11-14, 16-19, 21, 23, 25. Globivalvulina parapiciformis n. sp. 1. Subtransverse section. San Andres Fm. Sample MLY 4-14. 4. Subtransverse section. San Andres Fm. Sample MLY 3-4. 5. Subtransverse section. San Andres Fm. Sample MLY 3-7. 6. Subtransverse section. San Andres Fm. Sample MLY 6-12a. 7. Transverse megalospheric? section. San Andres Fm. Sample MLY 3-9 (already illustrated by Brose et al., 2013, figure 6.6). 9. Subtransverse section. San Andres Fm. Sample MLY(2) 4-11. 11. Subtransverse section. San Andres Fm. Sample MLY 6-31. 12. Subtransverse section. San Andres Fm. Sample MLY 5-11. 13. Subtransverse section. San Andres Fm. Sample MLY 5-11a. 14. Transverse section. San Andres Fm. Sample MLY 5-24a. 16. Transverse section. San Andres Fm. Sample MLY 8-2. 17. Subtransverse section. San Andres Fm. Sample MLY 6-4. 18. Subtransverse section. San Andres Fm. Sample MLY 6-3. 19. Transverse section. San Andres Fm. Sample MLY 6-2. 21. Transverse megalospheric section. San Andres Fm. Sample MLY 2-1. 23. Subtransverse section. San Andres Fm. Sample MLY 5-7d. 25. Subtransverse section. San Andres Fm. Sample MLY 6-9. 2-3, 8, 10, 15, 20, 22, 24. Globivalvulina novamexicana n. sp. 2. Oblique subtransverse section. San Andres Fm. Sample MLY 3-2. 3. Transverse section. San Andres Fm. Sample MLY 3-6. 8. Subaxial section. San Andres Fm. Sample MLY 3-10. 10. Oblique subtransverse section. San Andres Fm. Sample MLY 4-4. 15. Transverse section. San Andres Fm. Sample MLY 3-7a. 20. Subtransverse section. San Andres Fm. Sample MLY 6-1. 22. Subtransverse section. San Andres Fm. Sample MLY 8-8. 24. Subtransverse section. San Andres Fm. Sample MLY 5-19. Scale bars equal $0.10 \mathrm{~mm}$. 
Synonyms. Pseudoglomospira auctorum non Bykova in Bykova and Polenova, 1955; Glomospira auctorum non Rzehak, 1885; Tansillites Nestell and Nestell, 2006.

Description. Small glomospiroid, bilocular, tubular, undivided tests. Wall porcelaneous. Aperture terminal simple.

Occurrence. Early Pennsylvanian-Late Permian, cosmopolitan.

Hemigordiellina cf. elegans (Lipina, 1949)

Figures 34.11, 34.12

? 1949 Glomospira elegans Lipina, p. 206-207, pl. 2, figs. 11, 12, 16; pl. 7, fig. 5 .

v. 2013b Hemigordiellina cf. elegans (Lipina) Vachard, Krainer and Lucas, p. 348 (no illustration).

Description. Short glomospire. Lateral sides of spire slightly inflated. Peripheral margin rounded to slightly angular. Whorls involute. Whorl sutures weak to moderate. Chamber walls thin. Measurements: $D=0.07-0.22 \mathrm{~mm}$; whorls: $4-5 ; p=0.01$ $\mathrm{mm} ; \mathrm{h}=0.01-0.03 \mathrm{~mm} ; \mathrm{s}=0.01-0.02 \mathrm{~mm}$.

Occurrence. Middle?-late? Kungurian (=late Leonardian) of New Mexico (San Andres Fm: samples MLY(2) 4-5, MLY(2) 4-8a, MLY(2) 4-10a, MLY(2) 412, MLY(2) 5-15, SAR 18-3, SAR 18-3a).

\section{Hemigordiellina aff. elegans}

Figure 34.16

v. 2013b Hemigordiellina aff. elegans (Lipina); Vachard, Krainer and Lucas, p. 348 (no illustration).

Description. Only one section. Test ovoid, relatively elongate. Peripheral margin rounded to slightly angular. Whorls involute, partially evolute in last whorls. Whorl sutures relatively marked for the genus. Tube wall moderately thick. Lumen beanshaped and relatively large. Measurements: $D=$ $0.22 \mathrm{~mm}$; whorls: $4 ; \mathrm{p}=0.05 \mathrm{~mm}$; $\mathrm{h}=0.05 \mathrm{~mm}$; $\mathrm{s}=$ $0.01 \mathrm{~mm}$

Occurrence. Late? Kungurian (latest Leonardian) of New Mexico (San Andres Fm: sample SAR 14).

Hemigordiellina? cf. simplex (Harlton, 1928)

Figures 22.11, 33.1-33.14, 33.16, 33.18

? 1928 Glomospira simplex Harlton, p. 305, pl. 52, fig. 2a-c.

v. 2013b Hemigordiellina? cf. simplex (Harlton); Vachard, Krainer and Lucas, p. 348 (no illustration).

Description. This taxon is characterised by a large proloculus, a thin wall, high lumina and an evolute last whorl. $D=0.14-0.43 \mathrm{~mm}$; whorls: $3-4 ; p=0.01$ $0.04 \mathrm{~mm} ; \mathrm{h}=0.03-0.06 \mathrm{~mm} ; \mathrm{s}=0.01 \mathrm{~mm}$.
Comparison. Due to the evolute, plane last whorl, this taxon is transitional with Hoyenella Rettori, 1994 (if this Triassic genus possesses a porcelaneous wall, as we suppose). It differs from true $H$. simplex and from Hemigordiellina nanzhangensis (Zhang and Lin in Lin, 1978) n. comb. by its larger size.

Occurrence. Middle? Kungurian (late Leonardian) of New Mexico (San Andres Fm: samples MLY 3-1, MLY 3-11, MLY(2) 4-1, MLY(2) 4-2, MLY 4-8, MLY 4-11, MLY 4-12, MLY(2) 4-13, MLY 4-15, MLY 4-16, MLY 4-18, MLY 4-19, MLY 4-20, MLY 4-21, MLY(2) 5-1, MLY(2) 5-3, MLY(2) 5-4, MLY 5-5, MLY 5-12, MLY 5-15, MLY 5-16a, MLY 5-17, MLY 5-21, MLY(2) 5a-8, MLY 6-25a, MLY 8-7).

Hemigordiellina? aff. simplex

Figures 20.5-20.8, 20.10, 20.11, 34.15, 34.18

v. 2013b Hemigordiellina? aff. simplex (Harlton) Vachard, Krainer and Lucas, p. 348 (no illustration).

Description. Whorls involute. Lateral sides of spire flat to slightly inflated. Peripheral margin rounded. Chamber walls thin. Measurements: $D=0.16 \mathrm{~mm}$; $\mathrm{h}=0.03-0.05$ (rarely 0.07 ) $\mathrm{mm} ; \mathrm{s}=0.01 \mathrm{~mm}$.

Occurrence. Middle?-late? Kungurian (late Leonardian) of New Mexico (San Andres Fm: samples MLY(2) 4-2 and SAR 18-2).

Hemigordiellina? aff. pseudopusilla (Baryshnikov in Zolotova and Baryshnikov, 1980)

Figure 33.23-33.24

? 1980 Glomospira? pseudopusilla Baryshnikov in Zolotova and Baryshnikov, p. 76-77, pl. 1, figs. $1,2$.

? 1986 Glomospira? pseudopusilla Baryshnikov; Gorsky and Kalmykova, pl. 20, fig. 19.

v. 2013b Hemigordiellina? aff. pseudopusilla (Baryshnikov in Zolotova and Baryshnikov) - Vachard, Krainer and Lucas, p. 348 (no illustration).

Description. Whorls involute. Lateral sides inflated. Peripheral margin rounded. No umbilicus. No sutures. Chamber walls thin. Measurements: $D$ $=0.30-0.40 \mathrm{~mm}$; whorls: $5 ; \mathrm{p}=0.02-0.05 \mathrm{~mm} ; \mathrm{h}=$ $0.05-0.06 \mathrm{~mm} ; \mathrm{s}=0.02-0.03 \mathrm{~mm}$.

Remarks. The generic assignment of this taxon is questionable. It appears transitional between the entirely glomospiral Hemigordiellina, and Hoyenella which exhibits a second planispiral stage. Moreover, Hoyenella itself is a questionable genus. It was described with a porcelaneous wall, but this character is not really demonstrated; and, if it is porcelaneous, Hoyenella appears very similar to several porcelaneous genera: Brunsiella Reitlinger, 

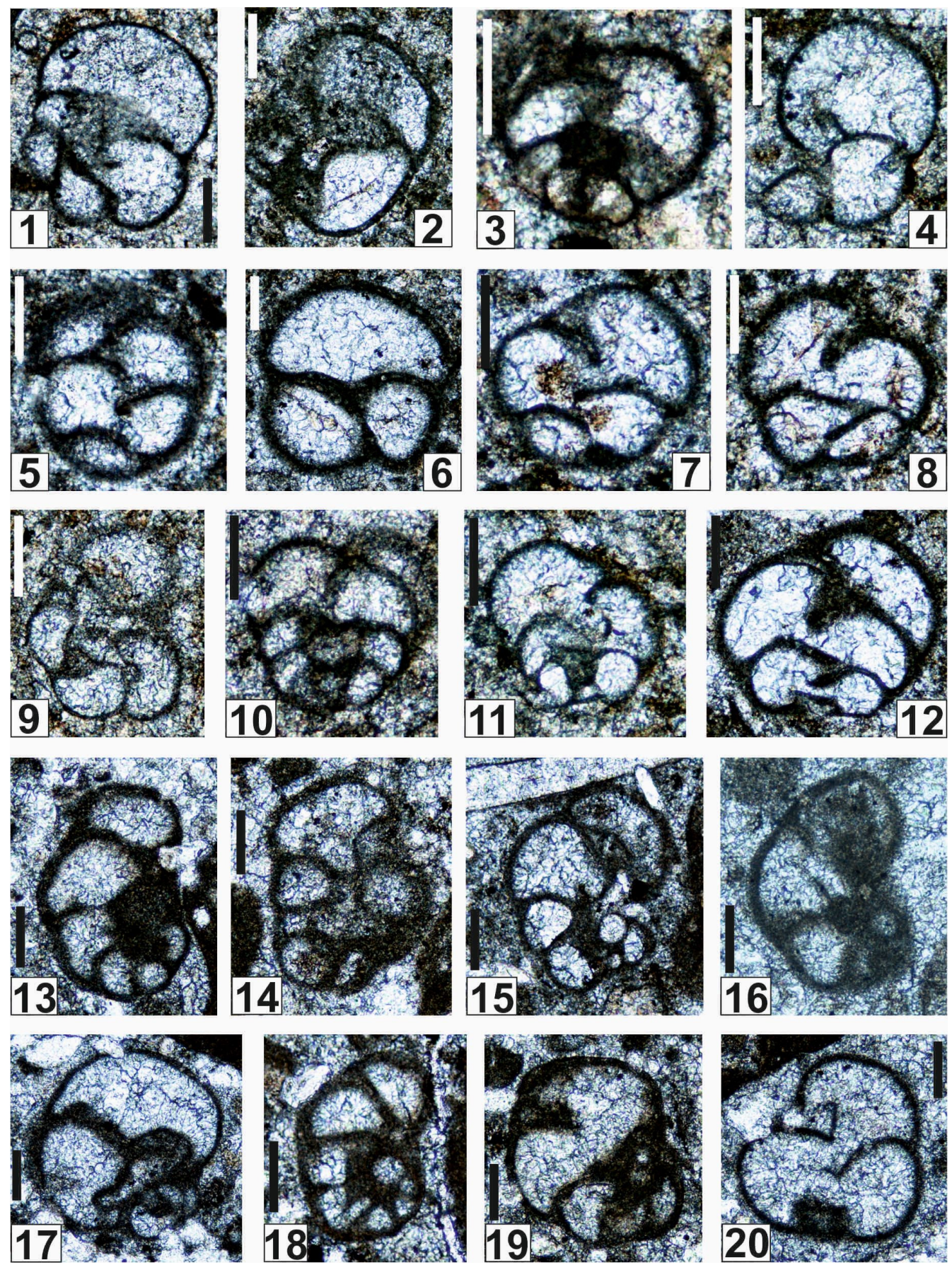

FIGURE 27. 1, 4, 9, 20. Globivalvulina retroseptata n. sp. 1. Subaxial section. San Andres Fm. Sample MLY 8-2a. 4. Subtransverse section. San Andres Fm. Sample MLY 5-23. 9. Subaxial section. San Andres Fm. Sample MLY 5-3. 20. Transverse section. Yeso Group. Sample MG 10-9. 2, 5-8, 12-19. Globivalvulina novamexicana n. sp. 2. Subtransverse section. San Andres Fm. Sample MLY 4-13. 5. Oblique subaxial section. San Andres Fm. Sample MLY 49. 6. Oblique section. San Andres Fm. Sample MLY4-1. 7. Axial section. San Andres Fm. Sample MLY 4-2. 8. Subaxial section. San Andres Fm. Sample MLY 4-6. 12. Axial section. San Andres Fm. Sample MLY 3-8. 13. Subtransverse section. Yeso Group. Sample MG 10-8 (already illustrated in Lucas et al., 2013b, figure 8G). 14. Subaxial section. Yeso Group. Sample MG 10-14. 15. Oblique subtransverse section. Yeso Group. Sample MG 10-17a. 16. Subtransverse section. Yeso Group. Sample MG 10-17. 17. Subaxial section. Yeso Group. Sample MG 10-7. 18. Subtransverse section. Yeso Group. Sample MG10 6. 19. Subaxial section. Yeso Group. Sample MG 10-6a. 3, 1011. Globivalvulina parapiciformis n. sp. 3. Axial section. San Andres Fm. Sample MLY 6-16. 10. Axial section. San Andres. Sample MLY 5-20a. 11. Axial section. San Andres Fm. Sample MLY 5-7c. Scale bars equal $0.10 \mathrm{~mm}$. 
1950; some Hemigordius Schubert, 1908 and Brunsispirella Vachard et al., 2005. Similarly, if its wall is dark-walled microgranular, it might be a synonym of the Fusulinata Brunsia Mikhailov, 1935; if agglutinated, it corresponds exactly to some taxa assigned to the agglutinated Textulariata Glomospirella Plummer, 1945. In fact, the type species of Glomospirella differs a lot from these small forms because it is a very large foraminifer, which can therefore be a synonym of Palaeonubecularia (= ?Minammodytes Henbest, 1963; = ?"Tolypammina" auct.), but, differs totally from the small Brunsia, Brunsiella, and Hoyenella.

The type species of Glomospirella (Glomospira umbilicata Cushman and Waters, 1927) is a very large taxon, with a diameter of up to $1.00 \mathrm{~mm}$. Its age is Middle/Late Pennsylvanian. However, the other species described in Glomospirella are small to very small (because they measure generally $0.25-0.40 \mathrm{~mm}$ ) with a second part of coiling markedly planispiral and evolute (consistent with the definition of Loeblich and Tappan, 1964, for example). Glomospirella sensu stricto is a particularly large genus with either: 1) a siliceously agglutinated test; or 2) a recrystallized porcelaneous test (similar to many taxa in the North American Pennsylvanian; e.g., Henbest, 1963; Vachard and Krainer, 2001a, 2001b); or, finally, 3) an agglutinated and porcelaneous test as in Pseudospira or Palaeonubecularia (and, in general, many false tolypamminid forms of the Pennsylvanian). Furthermore, Glomospirella sensu Loeblich and Tappan, 1964 non Plummer, 1945 has at least two homeomorphs: 1) the Fusulinata Brunsia; and 2) the Miliolata Brunsiella and some Hemigordius sensu lato. Another homeomorph is Hoyenella sensu stricto (i.e., the Triassic representatives of "Glomospirella" of the authors), the range of which has been extended to the Permian by Gaillot and Vachard (2007). The Permian glomospirellids evidently have a porcelaneous wall, whereas the true microstructure of Triassic Hoyenella is not well established (porcelaneous, calcitic microgranular, aragonitic microgranular, or an uncharacteristic and unknown wall?).

$\mathrm{Gu}$ et al. (2007) used Glomospirella with a question mark, but did not explain why. Moreover, they compared for example G.? mamilla Gu, Feng and $\mathrm{He}, 2005$ (G.?: with a question mark) to G. robusta Scherp, 1962 (G.: without a question mark); whereas G.? curva Gu, Feng and He, 2005 is probably a Postcladella Krainer and Vachard, 2011.
Groves and Boardman (1999, p. 249) admitted a perfect homeomorphy of Brunsiella and Brunsia, as well as the same wall microstructure (i.e., dark-microgranular). Therefore, they require two successive derivations from the common ancestor Pseudoammodiscus; i.e., the first one in the EarlyMiddle Mississippian (for Brunsia), and the second one in the Middle Pennsylvanian-Early Permian (for Brunsiella). A lineage PseudoammodiscusBrunsiella-Hemigordius is also suggested by Groves and Boardman (1999). With such reasoning, Hoyenella will be a third derivation, in the Triassic. Similarly, we can admit a lot of derivations from "Pseudoammodiscus" auctorum and/or "Pseudoglomospira" auctorum, giving all the successive forms of the Lower Palaeozoic (previously called "Ammodiscus", "Cornuspira", "Rectocornuspira", and now Pseudoammodiscus, Pseudospira, Postcladella, etc.). As indicated by Tappan and Loeblich (1988), Pseudoammodiscus might give rise to all the Triassic order Involutinida, and subsequently all the modern Miliolata. Finally, the descendants of Pseudoammodiscus may appear too prolific and too diverse.

An alternative hypothesis was presented by Vachard et al. (2005), Gaillot and Vachard (2007) and Vachard et al. (2010), based on the particular aspect and exceptional preservation of the porcelaneous wall; i.e., amber-colored or tan-skin. This aspect is relatively common among the well-preserved Hemigordius (for example in the Early Permian microfacies from Iran illustrated by Alipour et al., 2013). We admit that Brunsiella is also porcelaneous and constitutes the ancestor of Hemigordius. The first specimens with a porcelaneous test are more difficult to characterise. Vachard et al. (2010) suggested that the first ones belong to the calcivertellids (e.g., Calcivertella, Ammovertella), and cornuspirids (either planispiral evolute: Cornuspira; or streptospiral: Hemigordiellina sensu Vachard and Beckary, 1991).

The status of Warnantella Conil and Lys in Conil et al., 1977, whose FAD is poorly known, is uncertain and it corresponds either to a Miliolata or a Fusulinata (for example, to "Pseudoglomospira" sensu lato, according to Reitlinger in Vdovenko et al., 1993, p. 55, plate 10, figures 8, 9). Apparently, all authors admit the porcelaneous nature of the calcivertellid wall (Loeblich and Tappan, 1964, 1987; Gaillot and Vachard, 2007; Vachard et al., 2010); nevertheless, Pronina (1994, figure 1, p. 22) proposed a phylogenetic tree, where calcivertellids are related to pseudoammodiscids as well as Hemigordius and Hemigordiopsis Reichel, 1945 

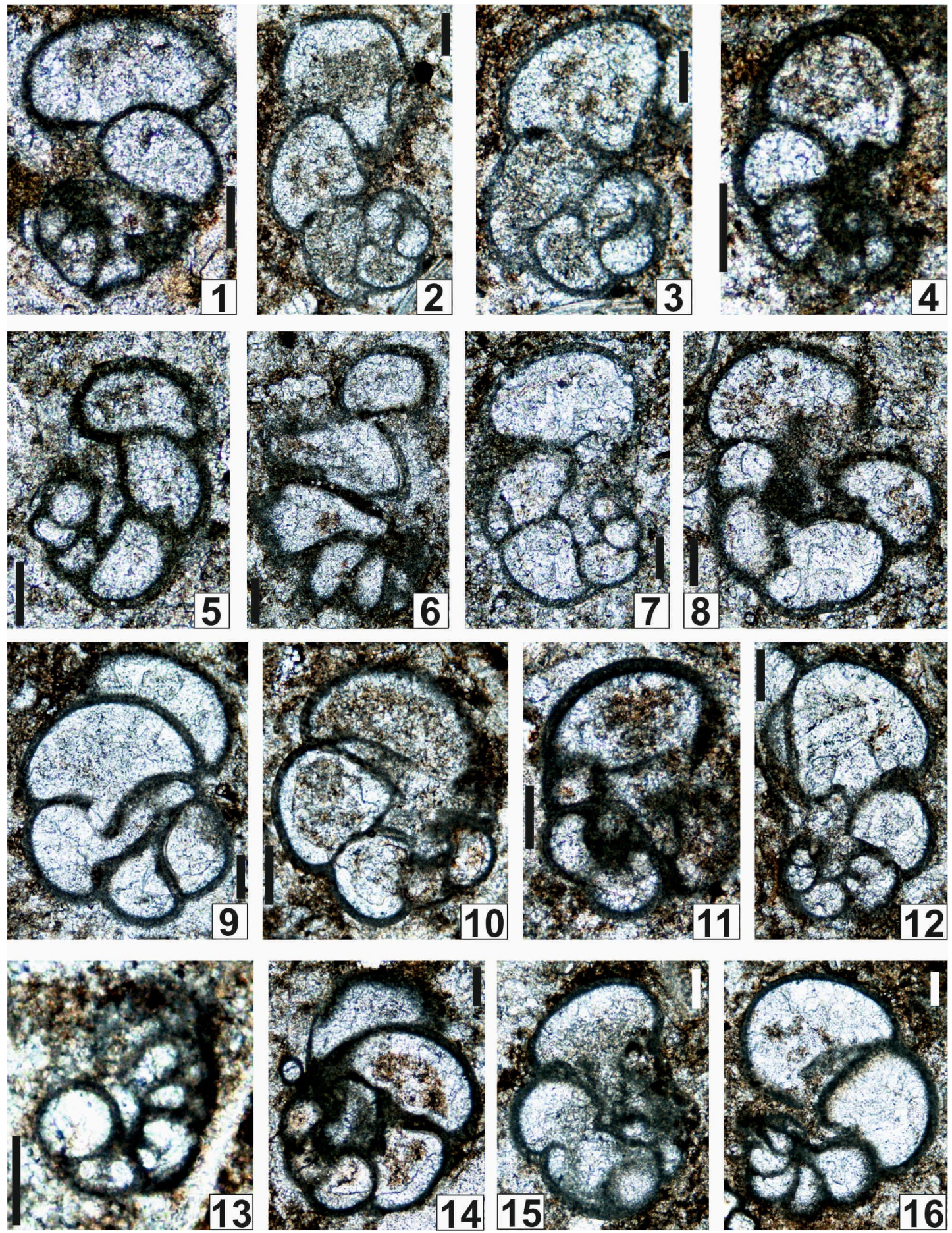

FIGURE 28. 1-3, 7. Globivalvulina retroseptata n. sp. 1. Transverse section. San Andres Fm. Sample SAR 13-5. 2. Transverse section. San Andres Fm. Sample SAR 13-5b. 3. Transverse section. San Andres Fm. Sample SAR 135c. 7. Transverse section. San Andres Fm. Sample SAR 8-5. 4-6, 8-12, 14-16. Globivalvulina praegraeca n. sp. 4. Transverse section. San Andres Fm. Sample SAR 13-7. 5. Transverse section. San Andres Fm. Sample SAR 8-2. 6. Subtransverse section. San Andres Fm. Sample SAR 8-3. 8. Subaxial section. San Andres Fm. Sample SAR 8-7a. 9. Subaxial section. San Andres Fm. Sample SAR 8a-2. 10. Subaxial section. San Andres Fm. Sample SAR 8a-5. 11. Axial section. San Andres Fm. Sample SAR 8a-5a. 12. Transverse section. San Andres Fm. Sample SAR 8a-18. 14. Subtransverse section. San Andres Fm. Sample SAR 8a-9. 15. Oblique subtransverse section. San Andres Fm. Sample SAR 8a-10. 16. Subtransverse section. San Andres Fm. Sample SAR 8a-12. 13. Globivalvulina parapiciformis n. sp. Transverse section. San Andres Fm. Sample SAR 8a-8a. Scale bars equal $0.10 \mathrm{~mm}$. 
(two genera for which a porcelaneous wall is also unanimously admitted). Inversely, if we admit the repetitive derivations from Pseudoammodiscus, the same reasoning leads to thinking that the derivations previously occurred in the Lower Palaeozoic, from the Ammodiscus of the literature. Consequently, in terms of wall microstructure, these primitive homeomorphs are not Fusulinata, but are Textulariata. Inversely, the Lower Palaeozoic forms are already Fusulinata, so, all the first forms of foraminifers are recrystallized Fusulinata and not Textulariata. Consequently, the megaevolution of the foraminifers during the Palaeozoic remains poorly known, but the schemes of Tappan and Loeblich (1988) or Pronina (1994) cannot be applied, either because there are misinterpretations of the Palaeozoic genera, or because of the lack of knowledge of the wall microstructures, respectively.

Occurrence. Early?-middle? Kungurian (late Leonardian) of New Mexico (Yeso Group: sample MG(2) 10-2. San Andres Fm: samples MLY 5-24, MLY 5-25, MLY(2) 5-10).

Genus PSEUDOSPIRA Reitlinger in Vdovenko, Rauzer-Chernousova. Reitlinger and Sabirov, 1993 nom. translat. herein

Type Species. Glomospira mikhailovi Reitlinger, 1950.

Description. Test attached, tubular, bilocular, undivided, with a coiling initially glomospiral and then elongated on the substrate, and serpentiform or oscillating. Wall porcelaneous mixed with a calcareous agglutinate.

Remarks. Some extant and fossil Miliolata exhibit a porcelaneous wall mixed with a siliceous agglutinate (Agglutinella El-Nakhal, 1983 and other Siphonapertinae Saidova, 1975; see Loeblich and Tappan, 1987; Tappan and Loeblich, 1988). Based on this microstructural similarity, Pseudospira is interpreted here as a Miliolata.

Pseudospira was introduced as a subgenus of Pseudolituotuba Vdovenko, 1971; however, the former has a porcelaneous agglutinated wall, whereas the latter has a microgranular agglutinated wall; consequently, they belong to two different classes, Miliolata and Fusulinata, respectively.

Pseudospira differs from Hemigordiellina by the attached habitat, terminal uncoiling and wall microstructure. From the other calcivertellids (and especially Palaeonubecularia), it differs in its agglutinated porcelaneous wall. From Tolypammina Rhumbler, 1895, it differs in a calcareous and not siliceous agglutinate; however, like the type species, many false Palaeozoic "Tolypammina" might belong to Palaeonubecularia, Pseudospira, Quasilituotuba Brazhnikova in Aizenverg et al., 1983, or Baryshnikovia Reitlinger in Vdovenko et al., 1993.

Occurrence. Middle Pennsylvanian-Early Permian, Donbass, Uzbekistan, New Mexico.

Pseudospira aff. ishimbaica (Lipina, 1949) Figures 22.9, 33.15, 33.21, 34.9

? 1949 Glomospira ishimbaica Lipina, p. 207-208, pl. 2, figs. 14, 15.

? 1980 Pseudoglomospira ishimbaica (Lipina); Rich, p. 45 (no illustration).

v. 2003 "Glomospira" or young Palaeonubecularia sp.; Krainer, Vachard and Lucas, pl. 3, fig. 22.

v. 2013b Pseudospira aff. ishimbaica (Lipina); Vachard, Krainer and Lucas, p. 348 (no illustration).

Description. Large glomospiroid part followed by an uncoiled or serpentiform tubular last part. Whorls: $3-4$; involute, partially evolute in some specimens. Peripheral margin rounded. Wall porcelaneous including a calcareous agglutinate. $\mathrm{D}=$ $0.20-0.55 \mathrm{~mm} ; \mathrm{h}=0.04-0.15 \mathrm{~mm} ; \mathrm{s}=0.01-0.04$ $\mathrm{mm}$.

Occurrence. Asselian (Nealian) of New Mexico (Krainer et al., 2003); middle? Kungurian (late Leonardian) of New Mexico (San Andres Fm: samples MLY 5-17, MLY 6-22, MLY 6-23).

\section{Superfamily ?CORNUSPIROIDEA Schulze 1854} nom. translat. Mikhalevich, 1988

Family ?CORNUSPIRIDAE Schultze, 1854 Genus OLGAORLOVELLA n. gen.

\section{zoobank.org/53210326-7BDC-4903-9232-C36ECA757A6D}

Etymology. Dedicated to $\mathrm{Dr}$ Olga Orlov-Labkovsky, Tel-Aviv University, for her contributions to Carboniferous and Permian biostratigraphy.

Synonyms. Pseudoagathammina (part.); Glomospira (part.).

Type Species. Olgaorlovella davydovi, n. gen. n. sp.

Diagnosis. Rounded to ovoid test, moderately large in diameter, with relatively numerous volutions. No pseudosepta. Proloculus spherical with flexostyle canal. Wall particularly thin and often recrystallized (light gray to whitish color).

Composition. Olgaorlovella davydovi n. gen. $\mathrm{n}$. sp.; Glomospira regularis Lipina, 1949 (sensu stricto); G. regularis sensu Wang, 1982 (plate 4, figure 24; another species); G. regularis sensu 

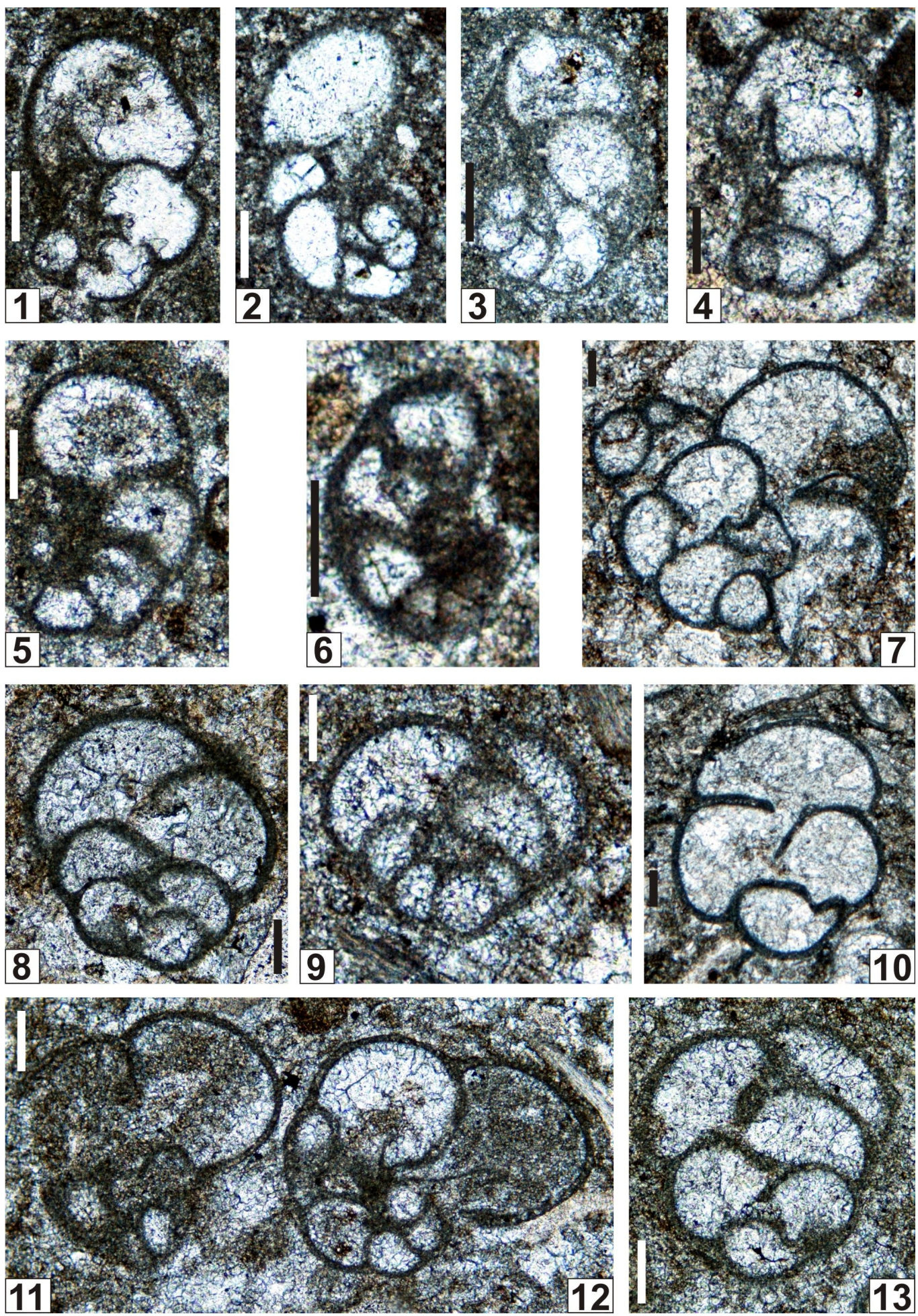

FIGURE 29. 1-4, 7. Globivalvulina retroseptata n. sp. 1. Transverse section. San Andres Fm. Sample SAR 19-2. 2. Transverse section. San Andres Fm. Sample SAR 19-3. 3. Transverse section. San Andres Fm. Sample SAR 19-4. 4. Subtransverse section with developed oral valvula. San Andres Fm. Sample SAR 20-1. 7. Teratogenic specimen. San Andres Fm. Sample SAR 3-1. 5, 8, 10-13. Globivalvulina praegraeca n. sp. 5. Transverse section. San Andres Fm. Sample SAR 20-3. 8. Axial section. San Andres Fm. Sample SAR 3-4. 10. Subaxial section. San Andres Fm. Sample SAR 8-1. 11-12. Two transverse sections. San Andres Fm. Sample SAR 7-4. 13. Subaxial section. San Andres Fm. Sample SAR 7-5. 6, 9. Globivalvulina novamexicana n. sp. 6. Subtransverse section. San Andres Fm. Sample SAR 20-4. 9. Axial section. San Andres Fm. Sample SAR 7-3. Scale bars equal $0.10 \mathrm{~mm}$. 
Vachard and Krainer, 2001b (plate 4, figures 16, 17, 19 (only); a third different species); Pseudoagathammina regularis sensu Filimonova, 2008 (plate 2, figure 21; a fourth species); G. dublicata Lipina, 1949 non Reitlinger, 1950; non Filimonova, $2008=$ ?O. davydovi, see below; nec $2010=$ another species; G. dublicata turajevica Baryshnikov in Baryshnikov et al., 1982; G. tenuifistula sensu Lin et al., 1990 (plate 2, figures 1, 2, 3); Pseudoagathammina orbicularia Lin, Li and Sun, 1990 (plate 27, figures 2, 3, 4, 5?, 6?); P. retroseptata sensu Filimonova, 2008 (plate 2, figure 23) and 2010 (plate 2, figure 10); Streblospira australae sensu Mamet (1996, plate 1, figure 35).

Remarks. Olgaorlovella n. gen. differs from the Permian (and Triassic?) "Glomospira" and Pseudospira by the type of wall, larger size, the proportionally very thin wall that is often recrystallized, and the flexostyle canal of the proloculus. Olgaorlovella n. gen. differs from Pseudoagathammina sensu stricto by the more regular coiling and the absence of agathamminid stage; nevertheless, some Pseudoagathammina described by Lin et al. (1990) and Filimonova (2010) probably correspond to our new genus.

The flexostyle canal of the proloculus of Olgaorlovella davydovi n. gen. n. sp. is conspicuous in Figure 24.3. Similarly, the holotype of Olgaorlovella regularis (Lipina) $\mathrm{n}$. comb. and a specimen of Vachard and Krainer (2001b, plate 14, figure 17) show a flexostyle canal.

Occurrence. Early Permian of Bashkorotostan (Russia), South China and the Carnic Alps. Artinskian of South America (Yaurichambi, Bolivia). Late? Kungurian (latest Leonardian) of New Mexico. Bolorian (late Kungurian) of Darvaz (Tajikistan) and Armenia. Lazarus effect or parallel evolution with the group Glomospira tenuifistula Ho, 1959 during the Triassic.

Olgaorlovella davydovi n. gen. n. sp.

Figures 12.7, 24.1-24.4, 24.7, 24. 10, 35.1-35.5, 35. $8,36.13$

zoobank.org/CA7ABCA4-554E-4057-83E6-60F034611221

? 2008 Pseudoagathammina dublicata (Lipina); Filimonova, pl. 2, fig. 19.

? 2010 Pseudoagathammina regularis; Filimonova, pl. 2, fig. 21.

v. 2013 Orthovertellopsis; Brose, Lucas and Krainer, fig. 6.12.

v. 2013b Neodiscus? sp. 2; Vachard, Krainer and Lucas, p. 348 (no illustration).
Etymology. For Dr. V. Davydov, Boise State University, to honor his knowledge of the International Code of Zoological Nomenclature.

Holotype. NMMNH P67954; Figure 24.10; sample SAR 11-2.

Paratypes. NMMNH P-67595-67599; Figure 24.14, 24.6-7.

Material. 45 specimens.

Locus Typicus. NMMNH locality 8903; San Andres Formation reference section in the San Andres Mountains near Rhodes Canyon (New Mexico).

Stratum Typicum. Late? Kungurian (latest Leonardian).

Diagnosis. Ovoid to subspherical test with a coiling transitional from streptospiral to oscillating to planispiral.

Description. Ovoid to subspherical test. Umbilicus absent. Sutures absent. Whorls involute. Lateral sides strongly inflated. Peripheral margin rounded. $\mathrm{D}=$ (0.35-0.400)-0.43-0.58 mm; $w=0.25-0.46 \mathrm{~mm}$; w/D = 0.60-0.87 (0.95); whorls: (rarely 3.5)-4-6; $p=$ (0.06)-0.08-0.09 mm; $\mathrm{h}=(0.05-0.06)-0.07-0.11$ $\mathrm{mm} ; \mathrm{s}=0.001 \mathrm{~mm}$.

Comparisons. O. davydovi differs from O. regularis by the more ovoid test, higher lumen and more whorls. A related taxon might be Agathammina sp. sensu Flügel et al. (1984, plate 32, figure 7; plate 34 , figures $1,2,3$ ). It is similarly morphologically transitional between Glomomidiella and Praeneodiscus and/or Neodiscus, but devoid of a relationship with true Agathammina, as well as late Midian (latest Middle Permian) in age.

Occurrence. Late? Kungurian (latest Leonardian) of New Mexico (San Andres Formation, reference section: samples SAR 8a-27, SAR(2) 11-1, SAR 11-2, SAR 11-3, SAR(2) 11-3, SAR(2) 11-3a, SAR(2) 11-4, SAR(2) 11-5, SAR 11-6, SAR 11-6b, SAR(2) 11-7, SAR(2) 11-8, SAR 11-9, SAR 11-10, SAR 11-11, SAR 11-12, SAR(2) 11-13, SAR(2) 1114, SAR(2) 11-15, SAR(2) 11-16, SAR(2) 11-7, SAR 11-18, SAR 11a-2, SAR 11a-3, SAR 11a-7, SAR 11a-8, SAR 11a-11, SAR 11a-14, SAR 11a15, SAR 13-4).

Family HEMIGORDIIDAE Reitlinger in Vdovenko, Rauzer-Chernousova, Reitlinger and Sabirov, 1993 Genus HEMIGORDIUS Schubert, 1908

Type Species. Cornuspira schumbergeri Howchin, 1895.

Description. Test free. Proloculus followed by a tubular, undivided chamber. Coiling initially streptospiral, more or less protuberant in the central part of the test, followed by a discoid planispiral involute part to occasionally semi-evolute or evolute in the 

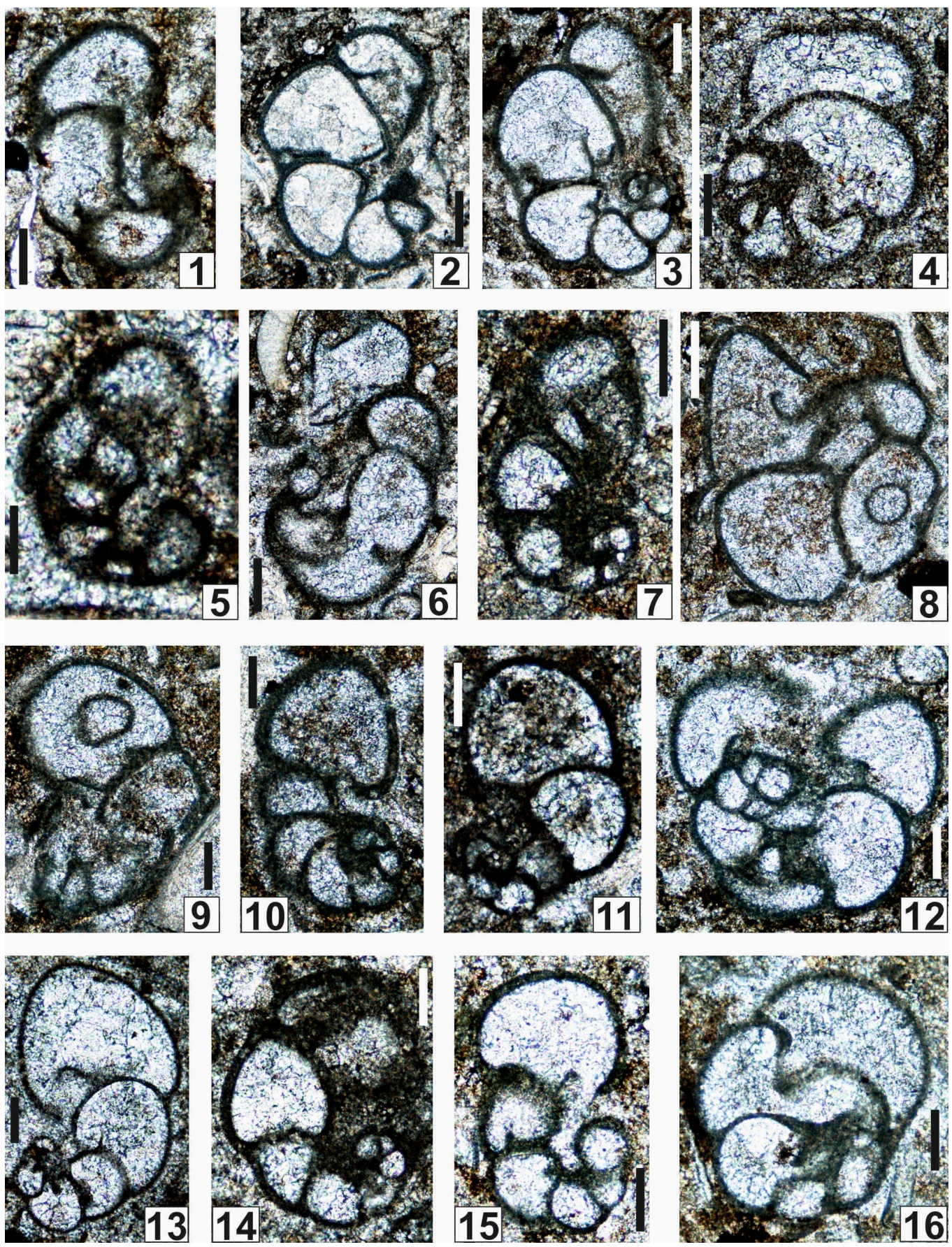

FIGURE 30. 1, 4-6, 8-10, 12, 14-15. Globivalvulina praegraeca n. sp. 1. Subtransverse section. San Andres Fm. Sample SAR 8a-13a. 4. Transverse section. San Andres Fm. Sample SAR 9-1. 6. Transverse section. San Andres Fm. Sample SAR 13-10. 8. Subaxial section. San Andres Fm. Sample SAR(2) 13-2. 9. Subtransverse section. San Andres Fm. Sample SAR(2) 13-6. 10. Transverse section. San Andres Fm. SAR 13-9. 12. Axial section showing the proloculus and the first whorl. San Andres Fm. Sample SAR(2) 8-21. 14. Transverse section. San Andres Fm. Sample MLY(2) 4-9. 15. Transverse section. San Andres Fm. Sample SAR 8-18. 2-3, 11, 13, 16. Globivalvulina retroseptata $\mathrm{n}$. sp. 2. Subtransverse section. San Andres Fm. Sample SAR 8a-19. 3. Transverse section. San Andres Fm. Sample SAR 8a-24. 11. Transverse section. San Andres Fm. Sample SAR 13a-7. 13. Transverse section. San Andres Fm. Sample MLY(2) 6-13 (already illustrated by Brose et al., 2013, figure 6.7). 16. Axial section. San Andres Fm. Sample SAR(2) 12-6. 5. Globivalvulina parapiciformis n. sp. Subtransverse section. San Andres Fm. Sample SAR 13-9. 7. Globivalvulina novamexicana n. sp. Transverse section. San Andres Fm. Sample SAR 13-12. Scale bars equal 0.10 $\mathrm{mm}$. 
last whorl. Lumen at the concavus stage. Wall porcelaneous, generally recrystallized as a dark microgranular one. Aperture at the end of the tubular chamber.

Remarks. There are probably five lineages of Hemigordius sensu lato. The first one has its FAD in North America (Groves, 1984) with H. harltoni Cushman and Waters, 1928a and then migrates at the end of the Moscovian into the Urals and Tethys with $H$. discoideus (Brazhnikova and Potievskaya, 1948) and H. simplex (Reitlinger, 1950). These primitive forms gave rise to the type species of the genus, $H$. schlumbergeri (Howchin, 1895), which is Late Pennsylvanian-Early Permian in age. This species generated a plexus of hemigordiids with an important marker Rectogordius Alipour and Vachard in Alipour et al., 2013 (= false Neohemigordius of the authors). Then, another lineage started with $H$. schlumbergeri sensu Foster et al. (1985; to rename) where the chamber lumina became concavus-angulatus to angulatus in shape (see below for the discussion of these terms); this latter taxon generated various Neodiscidae Lin, 1984 nom. translat. Gaillot and Vachard, 2007, especially in this study Glomomidiella and Praeneodiscus n. gen. (or Uralogordius in the Urals).

The fifth lineage during the Middle Permian is more poorly known, but it displays diversified small forms showing: 1) a long, semi-evolute to evolute secondary stage (Okimuraites Reitlinger in Vdovenko et al., 1993 = Discospirella Okimura and Ishii, 1981 homonym of Discospirella Loeblich and Tappan, $1961=$ ? Brunsispirella, according to Nestell et al., 2009); 2) entirely planispiral forms (Arenovidalina sensu Sosnina, 1977 (non? Ho, 1959); see also some unnamed taxa in Berczi-Makk et al., 1995 from the Wuchiapingian of Hungary); 3) sigmoidal to planispiral rhombic forms (Midiella Pronina, 1988 sensu stricto not auctorum); or 4) distally irregularly coiled forms (Pseudohemigordius Nestell and Nestell, 2006). Various forms with pseudosepta are probably related to these different lineages but difficult to link with them: Septagordius Gaillot and Vachard, 2007; Nikitinella Sosnina, 1983; Pseudomidiella Pronina-Nestell in ProninaNestell and Nestell, 2001, and several atypical Baisalina (non Reitlinger, 1965).

Occurrence. Bashkirian of North America. Cosmopolitan from late Moscovian to latest Permian.
Hemigordius aff. saranensis Baryshnikov in

Baryshnikov, Zolotova and Kosheleva, 1982

Figure 34.1-34.5

? 1982 Hemigordius saranensis Baryshnikov in Baryshnikov, Zolotova and Kosheleva, p. 24-25, pl. 7, fig. 13.

v. 2013b Hemigordius aff. saranensis Baryshnikov in Baryshnikov, Zolotova and Kosheleva; Vachard, Krainer and Lucas, p. 348 (no illustration).

Description. Short glomospiroid initial stage followed by a proportionally long planispiral part. Proloculus spherical, relatively large. Lumina slitshaped or low-crescentic. Wall surface smooth. No umbilici. Whorls involute, partially evolute in some specimens. Lateral sides of spire flat. Peripheral margin rounded. Wall black porcelaneous or often whitish neosparitized. $D=0.15-0.30 \mathrm{~mm} ; \mathrm{w}=0.05-$ $0.07 \mathrm{~mm}$; $/ \mathrm{D}=0.21-0.28$; whorls: $5-6 ; \mathrm{p}=0.01$ $0.02-(0.04) \mathrm{mm} ; \mathrm{h}=0.02-0.04 \mathrm{~mm} ; \mathrm{s}=0.01 \mathrm{~mm}$.

Remark. The observed taxon differs from true $H$. saranensis by the smaller proloculus and the smaller dimensions for the same number of whorls.

Occurrence. Early Kungurian of Preurals (Russia). Late? Kungurian (latest Leonardian) of New Mexico (San Andres Fm: samples SAR 11-5a, SAR 11a-12, SAR 11a-12a, SAR(2) 12-11, SAR 13-5a, SAR 13-5d, SAR 13-8, SAR 13-11, SAR 20-5).

Hemigordius? sp.

Figure 32.7-32.10

Description. Umbilicus comprises all whorls. Sutures absent. Whorls evolute, partially involute in some specimens. Lateral sides flat to slightly inflated. Peripheral margin round to slightly angular. Chamber walls thin. Measurements: $D=0.55$ $\mathrm{mm} ; \mathrm{w}=0.15 \mathrm{~mm}$; whorls: $4 ; \mathrm{p}=0.05 \mathrm{~mm} ; \mathrm{h}=0.07$ $\mathrm{mm} ; \mathrm{s}=0.01 \mathrm{~mm}$.

Occurrence. Kungurian (late Leonardian) of New Mexico.

Family ?NEODISCIDAE Lin, 1984 nom. translat. Gaillot and Vachard, 2007

Genus GLOMOMIDIELLA Vachard, Rettori, Angiolini and Checconi, 2008

Type Species. Glomomidiella nestellorum Vachard, Rettori, Angiolini and Checconi, 2008.

Description. Test ovoid, circular or triangular, bilocular, undivided. The coiling is almost entirely streptospiral, but becomes planispiral and perhaps a little uncoiled at the end of the tube growth. Sutures weakly marked. Tubular chamber initially undivided, but rapidly showing some pseudosepta. 

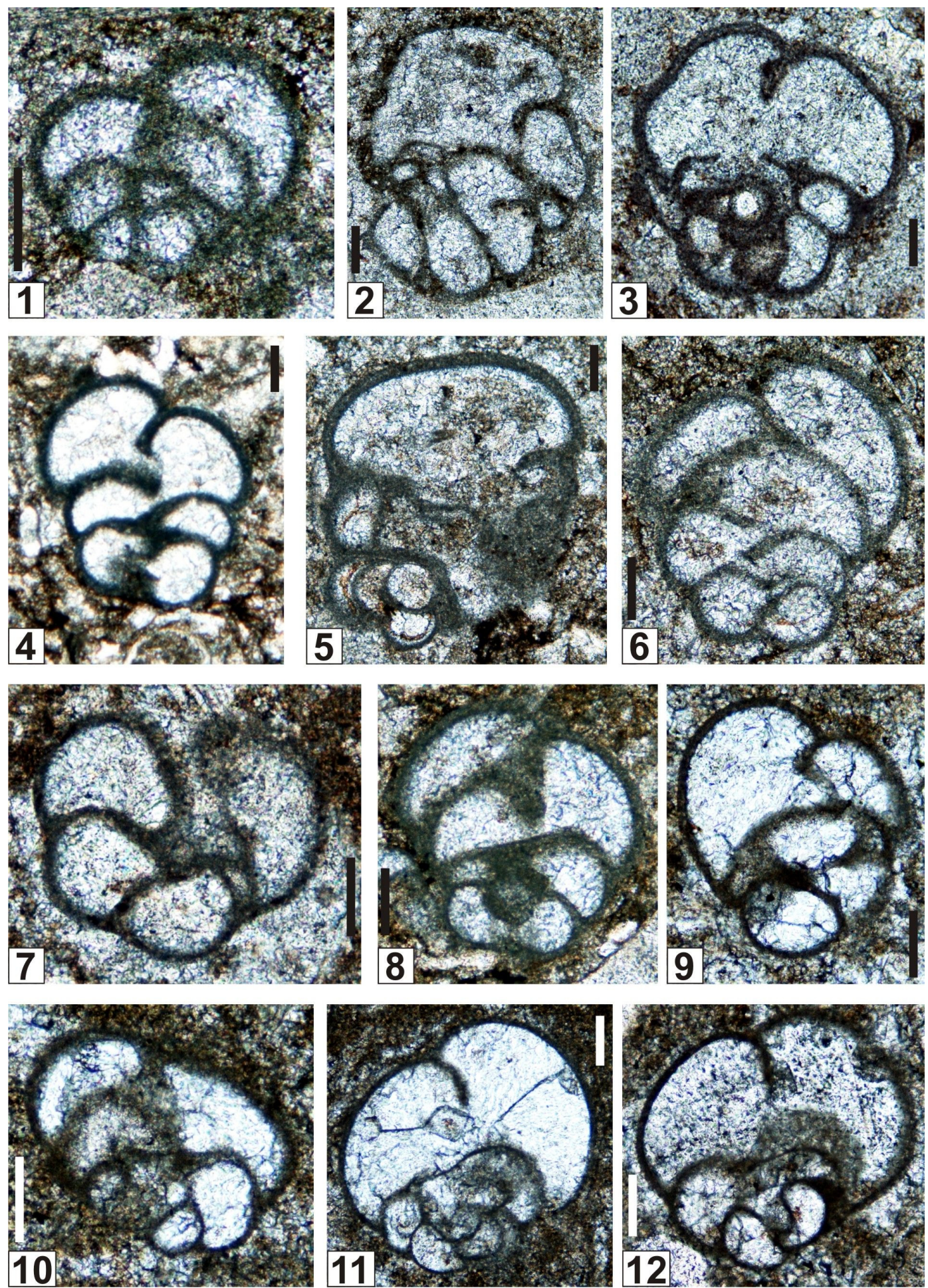

FIGURE 31. 1. Globivalvulina novamexicana n. sp. Axial section. San Andres Fm. Sample SAR 8-4. 2-8. Globivalvulina praegraeca n. sp. 2. Subtransverse section. San Andres Fm. Sample SAR 8-6. 3. Axial section. San Andres Fm. Sample SAR 8-7. 4. Subaxial section. San Andres Fm. Sample SAR 8a-10a. 5. Paratype. Oblique section. San Andres Fm. Sample SAR 8a-20. 6. Subaxial section. San Andres Fm. Sample SAR 8a-21. 7. Subaxial section. San Andres Fm. Sample SAR 12-2. 8. Subaxial section. San Andres Fm. Sample SAR 13-1. 9-12. Globivalvulina retroseptata n. sp. 9. Oblique subaxial section. San Andres Fm. Sample SAR 13a-7. 10. Subaxial section. San Andres Fm. Sample SAR 13a-1. 11. Oblique subaxial section. San Andres Fm. Sample SAR 13a-8. 12. Axial section. San Andres Fm. Sample SAR 13a-9. Scale bars equal $0.10 \mathrm{~mm}$. 
Lumina crescentic to semicircular. Wall porcelaneous, often neosparitized. Aperture terminal.

Composition. See Vachard et al. (2008, p. 354) and add: Agathammina pusilla sensu Berczi-Makk, 1978 (plate 1, figure 1); Archaediscus cf. milliolides (sic) sensu Berczi-Makk, 1978 (plate 3, figure. 4); A. milliolides (sic) sensu Berczi-Makk, 1978 (plate 3, figure 5); Orthovertella sp. sensu Wang, 1982 (plate 4, figure 2); Baisalina sp. of B. pulchra group sensu Okimura et al. (1985, plate 1, figure 9); Glomospira compressiformis Igonin, 1998; Hemigordius sp. sensu Panzanelli-Fratoni et al. (1987, plate 9, figure 18; only); Neodiscus grandis Lin, Li and Sun, 1990; Glomospira ishimbaica sensu Lin, Li and Sun, 1990 (part.: plate 1, figure 28 only); Hemigordius sp. sensu Kobayashi, 1997 (plate 4, figures 20, 21, 22, 23, 24); ?Agathammina sp. B sensu Kobayashi, 2001 (plate 2, figures 7, 8, 9); Neodiscus sp. A sensu Kobayashi, 2004 (figure 7.24-33); Hemigordius guangdongensis Gu, Feng and $\mathrm{He}, 2005$ (plate 1, figure 8); Neodiscus aff. qinglongensis sensu Vachard et al. (2005, plate 5, figures 3, 7, 8, 9, 10); Hemigordiscus baoqingensis sensu Vachard et al. (2005, plate 5, figures 4, 5, 6, 11); Baisalina miscella Nestell and Nestell in Nestell et al. (2006, plate 1, figures 35-38, plate 2, figures 1, 2, 3, 4, 5, 6); B. americana Nestell and Nestell, 2006 (plate 2, figures 28, 29, 30, 31, 32, 33, 34, 35, 36); Neodiscopsis ambiguus Gaillot and Vachard, 2007; Hemigordius sp. B sensu Kobayashi, 2007 (figure 3.18-19); Glomospira darvasica Filimonova, 2008 (plate 2, figure 24); Glomomidiella nestellorum sensu Song et al. (2009, figure 8.33-34 = another species); Glomospira ex gr. aquilonaris sensu Filimonova, 2010 (plate 2, figure 20) non Konovalova, 1962; Glomomidiella sp. sensu Song et al. (2011, figure 6.46); Glomomidiella sp. A sensu Kobayashi, 2012 (figures 7.1013, 7.16-17, 9.1-8); G. sp. A sensu Kobayashi, 2012 (figure 7.18-19).

Comparison. Glomomidiella differs from Neodiscopsis Gaillot and Vachard, 2007 by a spherical test, streptospiral coiling and less developed pseudo-septa. Neodiscopsis sensu stricto; i.e., as typified by Hemigordius specialis Lin, Li and Sun, 1990 , is probably a junior synonym of Pseudomidiella Pronina-Nestell in Pronina-Nestell and Nestell, 2001 and/or Baisalina Reitlinger, 1965. However, Neodiscopsis ambiguus differs from this group and is probably more closely related to Glomomidiella ex gr. infrapermica $\mathrm{n}$. sp.

Occurrence. Artinskian-Changhsinghian, Tethys and Ural Ocean carbonate platforms.
Glomomidiella infrapermica n. sp.

Figures 22.1, 22.3, 23.1, 23.3, 23.7, 23.8, 35.9, $35.11,35.14,36.1-36.12,36.16$

zoobank.org/D88B37EB-ED93-4EAA-899C-6C338B784706

? 1982 Orthovertella sp.; Wang, p. 19, pl. 4, fig. 2.

v. 2013b Orthovertellopsis; Lucas, Krainer and Voigt, fig. $8 \mathrm{I}$.

v. 2013b Orthovertella? sp. 1 (partim); Vachard, Krainer and Lucas, p. 348 (no illustration).

Etymology. Latin infrapermicus, from the Lower Permian strata.

Holotype. NMMNH P-67600; Figure 22.1; sample MG 10-22.

Paratypes. NMMNH P-67601-67605; Figures 22.3, 23.1, 23.3, 23.7-8.

Material. 35 specimens.

Locus Typicus. NMMNH locality 8904; Yeso Group, Los Vallos Formation, Torres Member, Massacre Gap in the southern Fra Cristobal Mountains (New Mexico).

Stratum Typicum. Early? Kungurian (late Leonardian).

Diagnosis. Large Glomomidiella with weak pseudosepta, numerous whorls and last whorls semievolute to evolute.

Description. Test ovoid to circular or triangular (D $=($ rarely 0.24$)-0.35-0.69 \mathrm{~mm})$. The spherical proloculus is proportionally very large (up to $0.09 \mathrm{~mm}$ ). The coiling is almost entirely streptospiral, but becomes planispiral and perhaps a little uncoiled at the end of the tube growth. There are (rarely 3.5)4-5 involute whorls. Sutures weakly marked between the different whorls of coiling. Lateral sides of spire irregular. Peripheral margin rounded. No umbilicus. The tube is undivided at the beginning but can show some pseudosepta in the two last whorls (Figures 22.1, 22.3, 23.1, 23.3, 23.7-8). Tube walls moderately thick to thick $(0.02-0.05$ $\mathrm{mm}$ ), always and entirely neosparitized. Lumina crescentic $(\mathrm{h}=0.06-0.13 \mathrm{~mm}$ ).

Remarks. Orthovertella sp. sensu Wang, 1982 is remarkably similar but larger $(D=1.25 \mathrm{~mm})$. The new species differs from $G$. nestellorum by lower lumina, more numerous whorls and occasionally a semi-evolute last whorl. It differs from Glomomidiella americana (Nestell and Nestell, 2006) n. comb. by less developed pseudosepta and higher lumina; from Glomomidiella miscella (Nestell and Nestell in Nestell et al., 2006) n. comb., which is very similar and probably the direct descendent of G. infrapermica n. sp.; the latter species differs by smaller dimensions of the test and the proloculus and especially by lower chambers $(h=0.10-0.18$ 

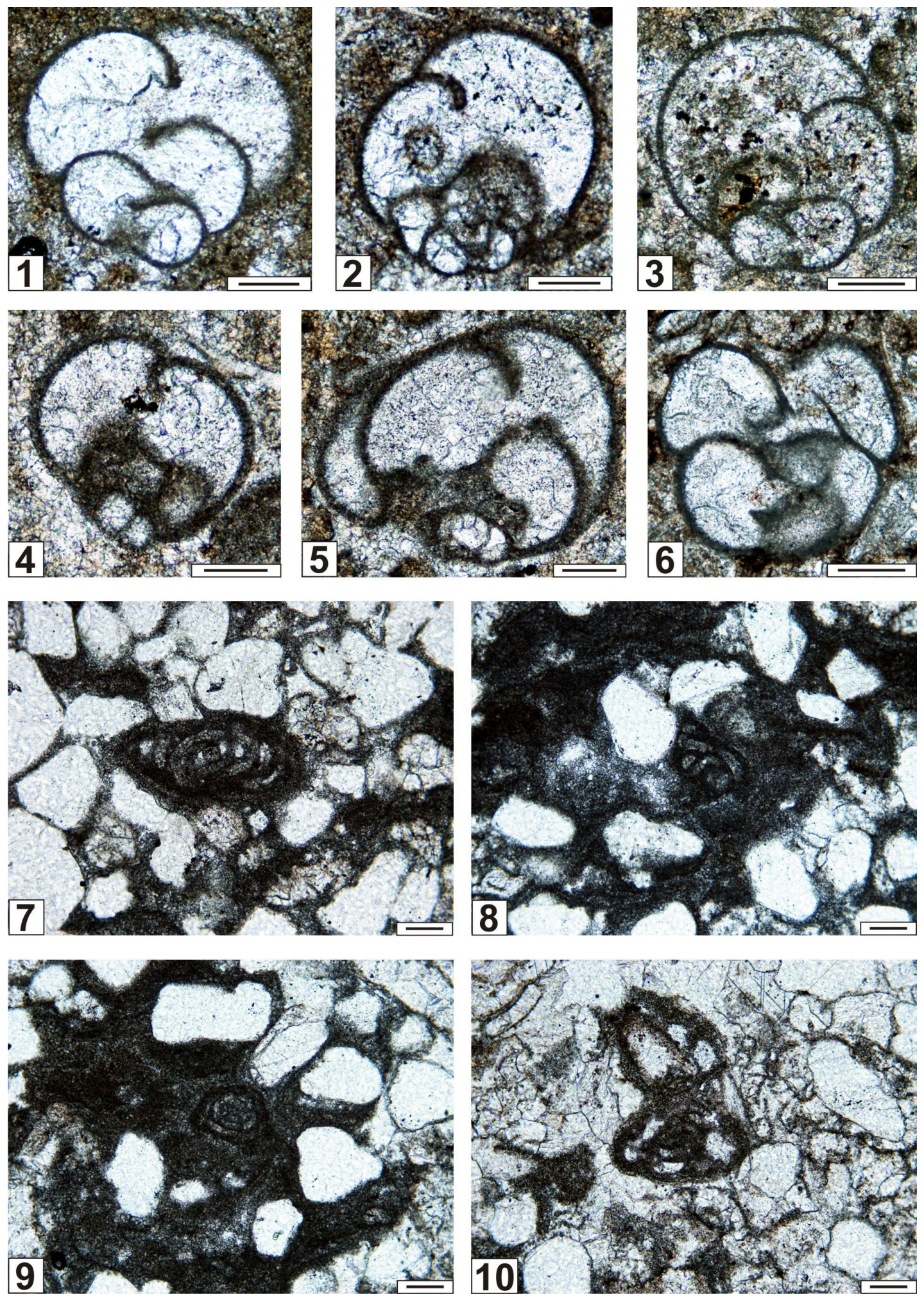

FIGURE 32. 1-3, 6. Globivalvulina retroseptata n. sp. 1. Subaxial section. San Andres Fm. Sample SAR 13a-10. 2. Oblique subaxial section. San Andres Fm. Sample SAR 13a-11. 3. Subaxial section. San Andres Fm. Sample SAR 20-6. 6. Axial section. San Andres Fm. Sample SAR (A-1§). 4-5. Globivalvulina novamexicana n. sp. 4. Oblique subaxial section. San Andres Fm. Sample SAR 20-8. 5. Subaxial section. San Andres Fm. Sample SAR 20-9. 7-10. Hemigordius? sp. Four sections. San Andres Fm Sample SAR 1. Scale bars equal $0.10 \mathrm{~mm}$. 
$\mathrm{mm}$ ); and from Glomomidiella darvasica n. comb., another similar species, by larger dimensions, a smaller proloculus, and more whorls (5-7).

Neodiscus grandis Lin, Li and Sun, 1990 is relatively similar to $G$. infrapermica $\mathrm{n}$. sp., although much larger $(D=1.09-1.51 \mathrm{~mm})$, but it is also related to some species of Iran and Armenia that exhibit sporadic pseudosepta and even rare true septa (materials of Mobin Ebrahim Nejad and Gevorg Grigoryan), and consequently are apparently convergent with Baisalina.

Occurrence. Kungurian (late Leonardian) of New Mexico (Yeso Group, Los Vallos Formation, Torres Member, Massacre Gap: samples MG 10-2, MG(2) 10-3, MG(2) 10-4, MG(2) 10-5, MG(2) 10-7b, MG(2) 10-7c, MG(2) 10-8, MG(2) 10-9, MG(2) 1010, MG(2) 10-11, MG 10-12, MG(2) 10-13, MG 1015, MG 10-16, MG 10-22, MG 10-25, MG(2) 12-7). San Andres Formation, McLeod Hills: samples MLY 6-26, MLY(2) 5-12, MLY(2) 5-19a, MLY(2) 519c, MLY(2) 5-20, MLY(2) 5-24, MLY(2) 5a-5, MLY(2) 5a-6, MLY(2) 5a-7, MLY(2) 5a-15, MLY(2) 5a-22, MLY(2) 6-18, SAR 11-14). Permian of South China.

Genus PRAENEODISCUS n. gen.

zoobank.org/AABE7958-7961-4CFD-90FB-4FD54D6E34B1

Type Species. Praeneodiscus convexus n. gen. $n$. sp.

Etymology. Before (= prae) Neodiscus, similar genus.

Synonyms. Hemigordius sensu Grozdilova, 1956; Hemigordius (partim) sensu Filimonova, 2008, 2010; Midiella (partim) sensu Blajezowski, 2009.

Diagnosis. Test ovoid. Oscillating, involute coiling. Proloculus spherical followed by a tubular chamber in which lumina are initially semicircular and then ogival.

Composition. Praeneodiscus convexus n. gen. $\mathrm{n}$. sp.; P.? transitus n. gen. n. sp.; P. lipinae (Lipina, 1949) (= Glomospira? compressa Lipina, 1949 (plate 3, figures 1, 2; plate 7, figure 1) preoccupied by G. compressa Waters, 1928 as indicated by Rich, 1980); Glomospira? miranda Lipina, 1949; Hemigordius ovatus Grozdilova, 1956; $H$. longus Grozdilova, 1956; H. permicus Grozdilova, 1956; H. sp. sensu Zolotova and Baryshnikov, 1980; $H$. guandongensis sensu Lin et al., 1990; Neodiscus sp. A sensu Kobayashi, 1997 (plate 4, figure 10); Agathammina sp. A sensu Kobayashi, 2001 (plate 2, figure 2); ?Hemigordius sp. 4 sensu Krainer et al. (2003, plate 6, figure 34); ?Agathammina? sp. A sensu Kobayashi, 2004 (figure 7. 21); Neodiscus orbicus sensu Gu et al. (2005, plate 1, figure 9); Pseudoagathammina regularis sensu Filomonova,
2008 non Lipina, 1949 nec auctorum; $P$. dublicata sensu Filomonova, 2008 non Lipina, 1949 nec auctorum; Midiella? n. sp. sensu Krainer et al. (2009, plate 4, figures 1, 2, 3); Neodiscus plectogyraeformis sensu Song et al. (2009, figure 8.35-37).

Comparison. The new genus differs from Neodiscus Miklukho-Maklay, 1953 by less ogival lumina, smaller dimensions and less whorls and the difference of age (Neodiscus is Midian-Lopingian in age). In fact, after the work of Miklukho-Maklay (1953), little unquestionable material of this genus has been published, and many misinterpretations have been made. The best re-illustrated material is that of Kobayashi $(2006$, figure 4.1-13, 4.21) under the name of Neodiscus padangensis (Lange). It is relatively similar to our new genus; compare in particular the holotype of Praeneodiscus convexus $\mathrm{n}$. sp. (Figure 19.4) with the specimen of Kobayashi (2006, figure 4.5).

The new genus differs from Glomomidiella in the more ovoid to lenticular test, and coiling oscillating to terminally planispiral and not streptospiral. It differs from Uralogordius Gaillot and Vachard, 2007 which possesses the same shape of lumen, because this latter is entirely planispiral. It differs from Pseudoagathammina Lin, Li and Sun, 1990 by a more regular test and the absence of miliolid coiling. It differs from Hemigordius Schubert, 1908 by the type of coiling, the larger dimensions and the ogival lumen (semicircular in Hemigordius sensu stricto). All the subspecies of Hemigordius quinglongensis (Wang, 1976) orth. mut. (i.e., with "qu" more consistent with the Latin spelling) -quinglongensis, forma (sic), laxa and minima- belong to either Praeneodiscus or Neodiscus.

Among the specimens of $\mathrm{Lin}, \mathrm{Li}$ and Sun (1990), Neodiscus ovatus (Grozdilova) more resembles Neodiscus milliloides Miklukho-Maklay, 1953, whereas Neodiscus paraovatus Lin, Li and Sun, 1990 is more similar to true Praeneodiscus ovatus.

Occurrence. Rare in Kungurian (late Leonardian) beds of New Mexico. Early Permian of Japan. Late Early Permian of Bashkorotostan (Russia). MiddleLate Permian of Tethys and Japan.

Praeneodiscus convexus n. gen. n. sp.

Figures 22.4, 22.7, 22.8, 22.10, 22.12-22.14, $33.17,33.22,33.26,34.14$

zoobank.org/02EC9CA2-153A-4708-AFB6-AAFD3D882787

? v. 2009 Midiella? n. sp.; Krainer, Lucas and Vachard, pl. 4, figs. 1, 2, 3.

v. 2013 Midiella; Brose, Lucas and Krainer, fig. 6.11. 

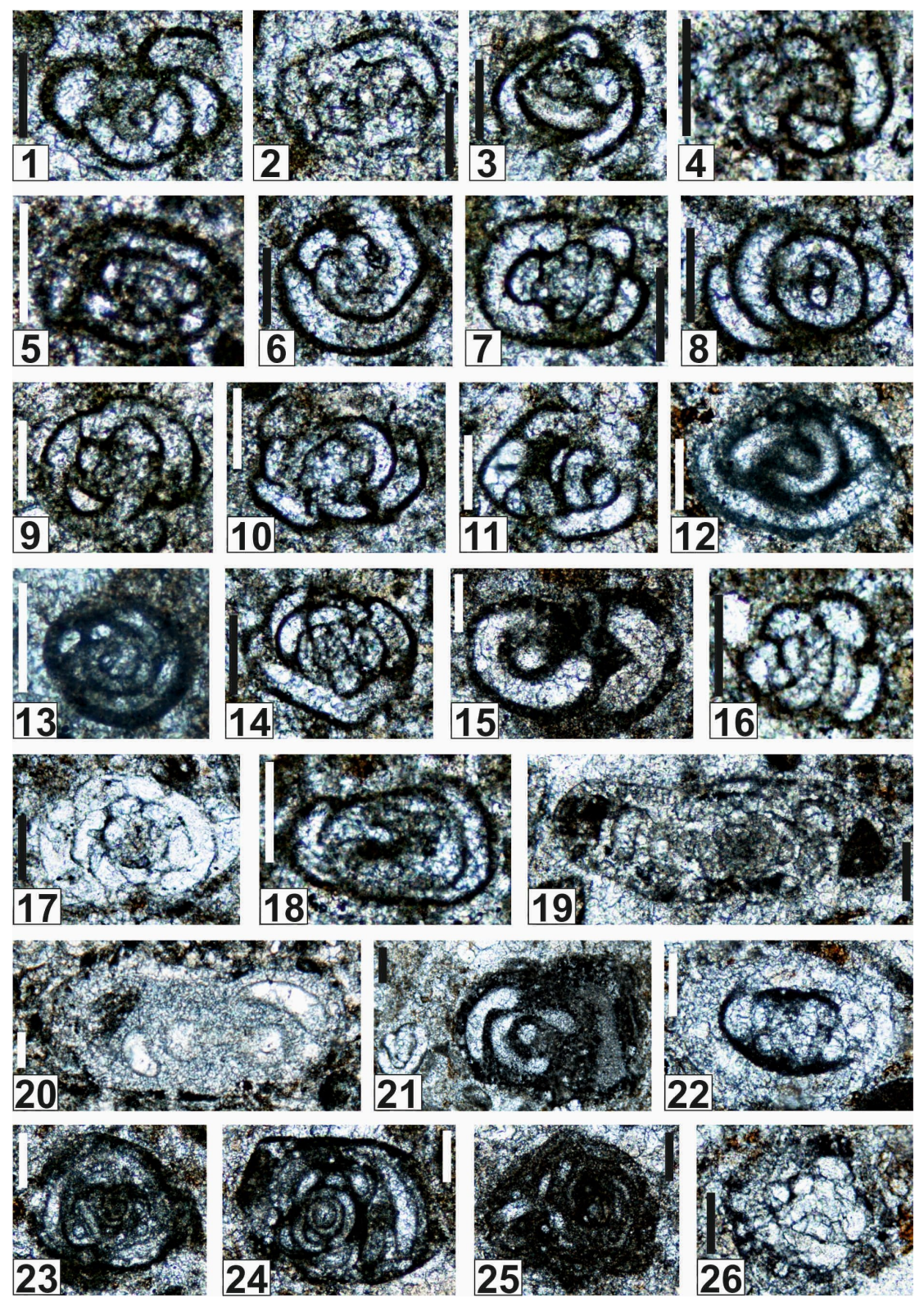

FIGURE 33. 1-14, 16, 18. Hemigordiellina? cf. simplex (Harlton, 1928). 1. Oblique subtransverse section. San Andres Fm. Sample MLY 3-1. 2. Oblique subaxial section. San Andres Fm. Sample MLY 3-11. 3. Subtransverse section. San Andres Fm. Sample MLY 4-8. 4. Subaxial section. San Andres Fm. Sample MLY 4-11. 5. Transverse section. San Andres Fm. Sample MLY 4-15. 6. Subtransverse section. San Andres Fm. Sample MLY 4-16. 7. Transverse section. San Andres Fm. Sample MLY 4-18. 8. Subaxial section. San Andres Fm. Sample MLY 4-19. 9. Subtransverse section. San Andres Fm. Sample MLY 8-7. 10. Subtransverse section. San Andres Fm. Sample MLY 4-20. 11. Subtransverse section. San Andres Fm. Sample MLY 5-15. 12. Subaxial section. San Andres Fm. Sample MLY 5-16a. 13. Transverse section. San Andres Fm. Sample MLY 5-5. 14. Subtranverse section. San Andres Fm. Sample MLY 4-12. 16. Oblique section. San Andres Fm. Sample MLY 6-25a. 18. Transverse section. San Andres Fm. Sample MLY 4-21. 15, 21. Pseudospira aff. ishimbaica (Lipina, 1949). 15. Subaxial section. San Andres Fm. Sample MLY 6-22. 21. Axial section with Hemigordiellina? cf. simplex (left). San Andres Fm. Sample MLY 5-17. 17, 22, 26. Praeneodiscus convexus n. gen. n. sp. 17. Oblique section. San Andres Fm. Sample MLY 5-16. 22. Transverse section. San Andres Fm. Sample MLY 5-8a. 26. Subaxial section. San Andres Fm. Sample MLY 5-9. 19-20. Orthovertellopsis protaeformis $\mathrm{n}$. gen. n. sp. 19. Subaxial section. San Andres Fm. Sample MLY 6-5. 20. Oblique subaxial section. San Andres Fm. Sample MLY 6-5a. 23-24. Hemigordiellina? aff. pseudopusilla (Baryshnikov in Zolotova and Baryshnikov, 1980). 23. Oblique section. San Andres Fm. Sample MLY 5-25. 24. Axial section. San Andres Fm. Sample MLY 5-24. 25. Palaeonubecularia? sp. Axial section. Perhaps also related with Ellesmerella (see Vachard et al., 2013b). San Andres Fm. Sample MLY 5-29. Scale bars equal $0.10 \mathrm{~mm}$. 
v. 2013b Neodiscus? ex gr. ovatus (Grozdilova); Vachard, Krainer and Lucas, p. 348 (no illustration).

Etymology. A species with regularly convex flanks.

Holotype. NMMNH P-67606; Figure 22.4; sample MG 10-24.

Paratypes. NMMNH P-67607-67612; Figure 22.78, 22.10, 22.12-14.

Material. 40 specimens.

Locus Typicus. NMMNH locality 8905; Yeso Group, Los Vallos Formation, Torres Member, Massacre Gap, southern Fra Cristobal Mountains (New Mexico).

Stratum Typicum. Early? Kungurian (late Leonardian).

Diagnosis. Praeneodiscus characterised by an ovoid test, medium to large in diameter, with oscillating coiling and an ogival lumen of the tubular chamber.

Description. Test ovoid. Oscillating involute coiling. No umbilici. No sutures. Wall surface smooth. Lateral sides of spire strongly inflated. Peripheral margin rounded. Proloculus spherical and small to moderate in size, followed by a tubular chamber with a diameter that is equal to the height of the third volution. $D=0.35-0.50-(0.70) \mathrm{mm} ; \mathrm{w}=(0.14)$ $0.22-0.35 \mathrm{~mm}$; $w / D=0.50-0.70$; whorls: (4)-5-6; $p$ $=0.01-0.02-(0.05-0.06) \mathrm{mm} ; \mathrm{h}=0.05-0.10 \mathrm{~mm} ; \mathrm{s}=$ 0.01-0.02 mm.

Remarks. The new species differs from Praeneodiscus arcticus n. comb. (formerly Midiella arctica) by a less sigmoidal coiling and a less inflated test (probably 0.66-0.71 in this latter species; although the ratio D/w indicated by Blazejowski, 2009 is 2.42.5; a probable lapsus calami for 1.4-1.5). It differs from P. compressus (Lipina, 1949) n. comb. by more whorls and more aligned last whorls. In contrast to P. ovatus (Grozdilova, 1956) n. comb. which is relatively similar in the shape of the tube lumina (i.e., crescentic, very wide, and well-developed in the lateral sides), the lumina of $P$. convexus $\mathrm{n}$. gen. $\mathrm{n}$. sp. are smaller, semicircular and limited to the central part of the test; the test, itself, of $P$. ovatus is much larger with $D=0.490-0.990$ $\mathrm{mm} ; \mathrm{w}=0.340-0.480 \mathrm{~mm}$ (for the same number of whorls: $5-6) ; \mathrm{h}=0.076-0.150 \mathrm{~mm} ; \mathrm{s}=0.026-0.038$ $\mathrm{mm}$. Praeneodiscus darvasica $\mathrm{n}$. comb. is similar to $P$. ovatus; it differs from $P$. convexus $\mathrm{n}$. gen. $\mathrm{n}$. $\mathrm{sp}$. by a shorter lumen of the chambers and a glomus more developed by the internal and external whorls. The holotype of $P$. convexus $\mathrm{n}$. gen. $\mathrm{n}$. sp. (Figure 19.4) is similar to Neodiscus padangensis sensu Kobayashi (2006, figures 4, 5), but differs by its smaller size $(1.00 \mathrm{~mm}$ for the Kobayashi's specimen), its smaller proloculus, and the total similarity of all lumina, whereas Kobayashi's specimen seems to exhibit a juvenarium, as does the holotype of N. milliloides Miklukho-Maklay, 1953 or Neodiscus cf. N. milliloides sensu Nestell et al., 2009 (plate 1, figures 30, 31). Praeneodiscus convexus $\mathrm{n}$. gen. $\mathrm{n}$. sp. differs from $P$. longus $\mathrm{n}$. comb. and $P$. permicus $\mathrm{n}$. comb. by the more inflated test and therefore a larger width; from Midiella zaninettiae (Altiner, 1978) by larger dimensions and a more oscillating coiling; from Neodiscus quinqlongensis Wang, 1976 by a test less inflated test with more volutions for a similar diameter; and from Neohemigordius zulumartensis Filimonova, 2010 by larger dimensions.

Occurrence. Early?-middle? Kungurian (late Leonardian) of New Mexico (Yeso Group, Los Vallos Formation, Torres Member: sample MG 10-24; San Andres Formation, McLeod Hills: samples MLY 5-4, MLY(2) 5-5, MLY 5-7, MLY 5-7a, MLY(2) 5-8, MLY 5-8a, MLY(2) 5-8a, MLY 5-9, MLY 5-13, MLY(2) 5-19b, MLY 5-21, MLY 5-30, MLY 5-31, MLY 5-32, MLY(2) 5a-14, MLY(2) 5a-16, MLY(2) 5a-17, MLY(2) 5a-18, MLY 8-1).

Class NODOSARIATA Mikhalevich, 1993

Subclass NODOSARIANA Mikhalevich, 1993 nom. correct. Mikhalevich, 1998

Order NODOSARIIDA Calkins, 1926

Superfamily ROBULOIDOIDEA Reiss, 1963 nom. translat. Loeblich and Tappan, 1964 emend. Gaillot and Vachard, 2007

Description. See Gaillot and Vachard, 2007.

Remarks. The study of the Nodosariata is particularly difficult and requires many biometric studies (Sellier de Civrieux and Dessauvagie, 1965; Gerke, 1967; Ruget, 1976; Hohenegger, 1997; Karavaeva and Nestell, 2007). Gaillot and Vachard (2007) proposed to subdivide the Palaeozoic Nodosariata into two superfamilies: 1) Robuloidoidea, with a primitive aperture (generally round, areal and simple), and; 2) Nodosarioidea Ehrenberg, 1838 nom. translat. Loeblich and Tappan, 1961 , with the typical stellate radial aperture of the post-Palaeozoic Nodosariata. The exact period of appearance of this type of aperture during the Permian is not yet precisely known, but it probably occurs during the evolution of Protonodosaria and/ or Nodosinelloides to Nodosaria sensu stricto (the two types of apertures are present together in the Nodosaria of Woszczynska's paper (1987): for example, $N$. candida Woszczynska, 1987, is really a Nodosaria "with a neck and radiate aperture", whereas N. polonica Woszczynska, 1987 belongs 

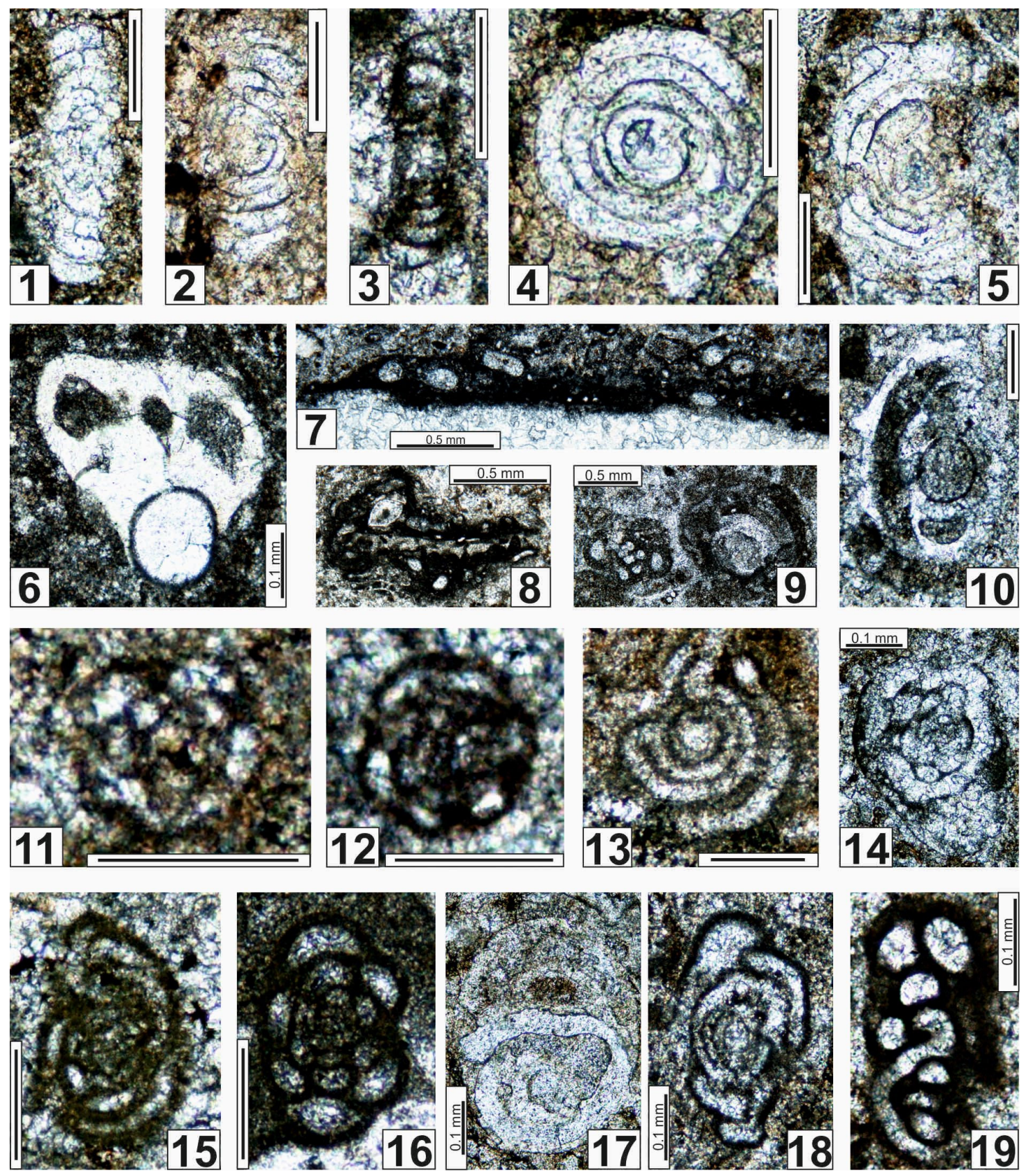

FIGURE 34. 1-5. Hemigordius aff. saranensis Baryshnikov in Baryshnikov, Zolotova and Kosheleva, 1982. 1. Subaxial section. San Andres Fm. Sample SAR 13-5d. 2. Subaxial section. San Andres Fm. Sample SAR 11-5a. 3. Axial section. San Andres Fm. Sample SAR 20-5. 4. Transverse section. San Andres Fm. Sample SAR 11a-12. 5. Subtransverse section. San Andres Fm. Sample SAR 13-11. 6, 10, 17. Orthovertellopsis calcitornellaeformis n. gen. n. sp. 6. Subtransverse section. San Andres Fm. Sample SAR 19-1. 10. Oblique section. San Andres Fm. Sample MLY 8-6. 17. Transverse section. San Andres Fm. Sample SAR(2) 11-10. 7-8. Palaeonubecularia sp. 7. Subtransverse section. San Andres Fm. Sample MLY 5-19. 8. Subtransverse section encrusting a Boueina? crassundia n. sp. San Andres Fm. Sample MLY(2) 5a-19. 9. Pseudospira aff. ishimbaica (Lipina, 1949). Two random sections. San Andres Fm. Sample MLY 6- 23. 11-12. Hemigordellina cf. elegans (Lipina, 1949). 11. Random section. San Andres Fm. Sample SAR 18-3a. 12. Random section. San Andres Fm. Sample SAR 18-3. 13. Ammovertella sp. Transverse section. San Andres Fm. Sample SAR 13-9a. 14. Praeneodiscus convexus n. gen. n. sp. Subaxial section. San Andres Fm. Sample MLY 5-32. 15, 18. Hemigordiellina? aff. simplex (Harlton, 1928). 15. Random section. San Andres Fm. Sample SAR 18-2. 18. Transverse section. San Andres Fm. Sample MLY(2) 4-2. 16. Hemigordellina aff. elegans (Lipina, 1949). Random section. San Andres Fm. Sample SAR 14. 19. Calcitornella cf. elongata Cushman and Waters, 1928a. Subtransverse section. San Andres Fm. Sample MLY(2) 5a-24. Scale bars 1-6, 10-19 equal $0.10 \mathrm{~mm}$. 
to another genus because of its "aperture terminal rounded").

Family PROTONODOSARIIDAE Mamet and

Pinard, 1992 emend. Gaillot and Vachard, 2007

Genus PROTONODOSARIA Gerke, 1959

Type Species. Nodosaria proceraeformis Gerke, 1952 (orth. mut. Gaillot and Vachard, 2007 for proceraformis).

Remarks. As noted here, and apparently in agreement with the redefinition of Groves (2000), Protonodosaria differs from Nodosinelloides, by the monolayered hyaline wall and the round, areal aperture. However, due to numerous other definitions, the name of the taxon described hereafter is followed by a question mark.

\section{Protonodosaria? sp.}

Figure 25.5

v. 2013 b Protonodosaria? sp.; Vachard, Krainer and Lucas., p. 348 (no illustration).

Description. Test cuneate to tongue-shaped, moderately elongate $(\mathrm{H}=0.50 \mathrm{~mm} ; \mathrm{w}=0.12 \mathrm{~mm} ; \mathrm{w} / \mathrm{H}$ $=0.24)$. Proloculus terminal, not prominent, spherical $(0.03 \mathrm{~mm}$ in diameter). Six chambers from small crescentiform to high spear-shaped crescentiform $(\mathrm{h}=0.11 \mathrm{~mm})$. Wall thin $(\mathrm{s}=0.01 \mathrm{~mm})$.

Remark. Nodosaria polonica Wozsczynska, 1987 is relatively similar in shape although smaller $(\mathrm{H}=$ $0.36 \mathrm{~mm}$ and $\mathrm{w}=0.08-0.11 \mathrm{~mm}$ ) for $6-8$ chambers. Occurrence. Middle? Kungurian (late Leonardian) of New Mexico (San Andres Fm: sample MLY 3-5).

\section{Genus NODOSINELLOIDES Mamet and Pinard, 1992}

Type Species. Nodosinelloides potievskayae Mamet and Pinard, 1996 (nom. nov. pro Nodosaria gracilis Potievskaya, 1962 pre-occupied).

Nodosinelloides longa (Lipina, 1949)

Figure 25.6-25.7, 25.10, 25.17-25.19

1949 Nodosaria longa Lipina, p. 216-217, pl. 4, fig. 6.

v. 2009 Nodosinelloides longa (Lipina); Krainer, Lucas and Vachard, pl. 5, figs. 2, 5, 6; pl. 6, fig. 23.

2010 Nodosinelloides longa (Lipina); Filimonova, p. 784,786 , pl. 5, fig. 19 (with synonymy).

v. 2013 Geinitzina; Brose, Lucas and Krainer, fig. 6.5.

v. 2013b Nodosinelloides longa (Lipina); Vachard, Krainer and Lucas, p. 348 (no illustration).

Description. Test cuneate, rectilinear, slightly curved to curved, very strongly elongate. Chambers subrectangular, fabiform to semicircular. Wall thin, bilayered, with small inner layer. $\mathrm{H}=0.24-$ $0.38-(0.60) \mathrm{mm} ; \mathrm{w}=0.05-0.09-(0.13) \mathrm{mm} ; \mathrm{w} / \mathrm{H}=$ 0.22-0.50; chambers: 7-12; $p=0.01-0.02-(0.03)$ $\mathrm{mm} ; \mathrm{h}=0.05-0.09 \mathrm{~mm} ; \mathrm{s}=0.01 \mathrm{~mm}$.

Remarks. Nodosinelloides longa might be characteristic of the early Kungurian according to Sosipatrova (1972) and Pronina (1999). However, it may be present as early as the earliest Permian (Vachard and Krainer, 2001a, 2001b; Krainer et al., 2009; Filimonova, 2010).

Occurrence. Late? Kungurian (latest Leonardian) of New Mexico (San Andres Fm: samples SAR 8a4a, SAR 8a-8, SAR 8a-17, SAR 11a-6, SAR 11a-9, SAR 12-4, SAR(2) 12-17).

Nodosinelloides netjaschewi (Cherdyntsev, 1914) Figure 25.11, 25.15, 25.20, 25.21

1914 Nodosaria netjaschewi Cherdyntsev, p. 38, pl. 2, figs. 3, 4 .

2000 Nodosinelloides netjaschewi (Cherdyntsev); Groves, p. 298 pl. 4, figs. 31, 32, 33, 34, $35,36,37,38,39,40$ (with synonymy).

v. 2009 Nodosinelloides netjaschewi (Cherdyntsev); Krainer, Lucas and Vachard, pl. 5, figs. 1, 4; pl. 65, fig. 25.

v. 2013b Nodosinelloides netjaschewi (Cherdyntsev); Vachard, Krainer and Lucas, p. 348 (no illustration).

Description. Test cylindrical and strongly elongate. Chambers angular. Measurements: $\mathrm{H}=0.13-$ $0.15-(0.39) \mathrm{mm} ; \mathrm{w}=0.03-0.04-(0.10) \mathrm{mm} ; \mathrm{w} / \mathrm{H}=$ $0.25-0,27$; chambers: $6-7 ; p=0.01-0.03 \mathrm{~mm} ; \mathrm{h}=$ $0.02-0.03(0.07) \mathrm{mm} ; \mathrm{s}=0.01 \mathrm{~mm}$.

Occurrence. Late? Kungurian (latest Kungurian) of New Mexico (San Andres Fm: samples SAR 1117, SAR 11-19/19a, SAR(2) 12-6, SAR 13a-2, SAR 20.2).

Genus NESTELLORELLA Gaillot and Vachard, 2007

Type Species. Pseudolangella pulchra Pronina in Kotlyar, Zakharov, Kropacheva, Pronina, Chediya and Burago, 1989.

\section{Nestellorella? sp.}

Figure 25.4

v. 2013b Nestellorella? sp. - Vachard, Krainer and Lucas, p. 348 (no illustration).

Description. Test wide cuneate, moderately elongate, with chambers fabiform (i.e., semi-circular) or trapezoidal internally, and subpentagonal externally. Wall thick. Aperture simple, depressed. $\mathrm{H}=$ $0.32 \mathrm{~mm} ; \mathrm{w}=0.12 \mathrm{~mm} ; \mathrm{w} / \mathrm{H}=0.38$; chambers: $6 ; \mathrm{p}$ $=0.02 \mathrm{~mm} ; \mathrm{h}=0.06 \mathrm{~mm} ; \mathrm{s}=0.02 \mathrm{~mm}$. As our 

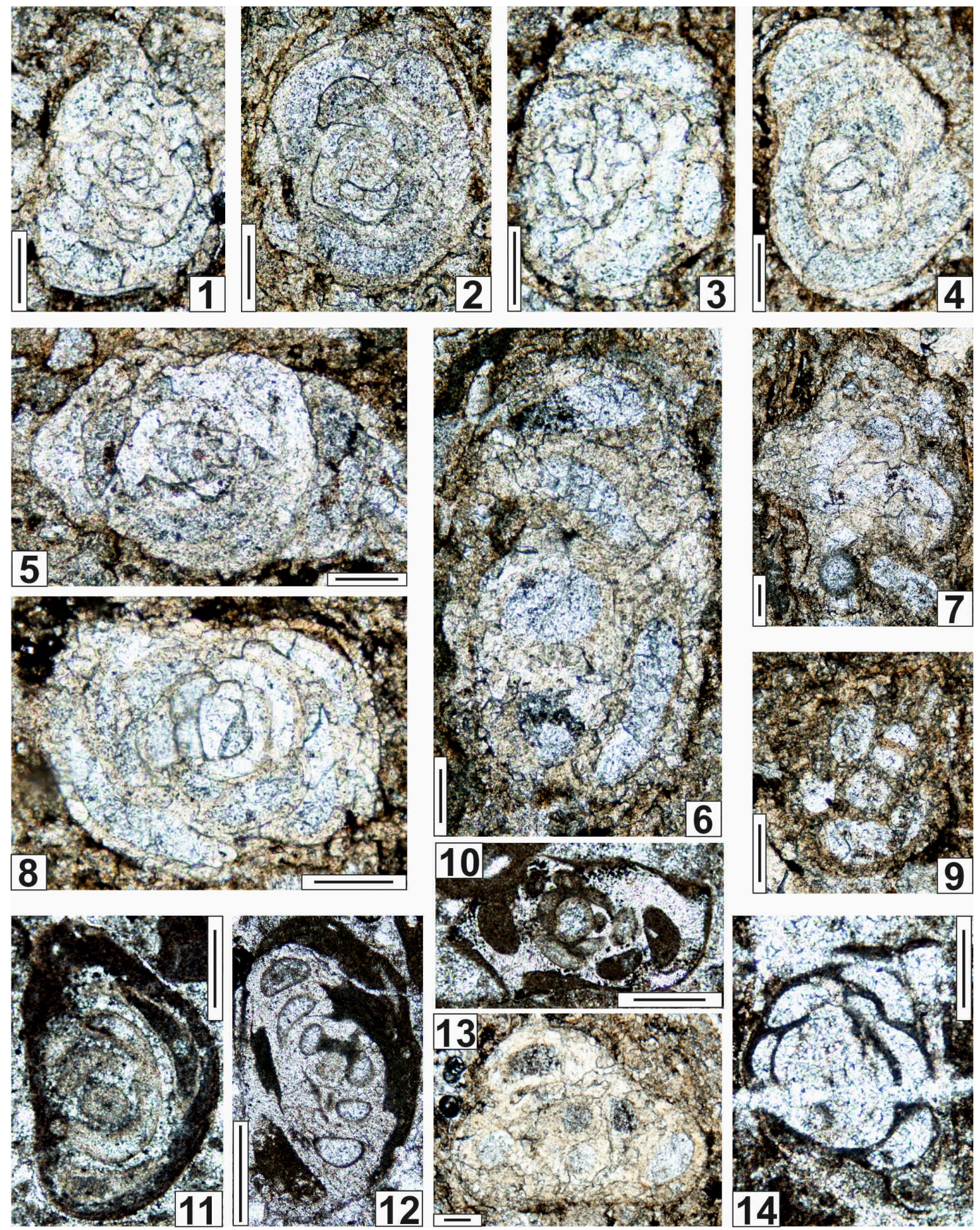

FIGURE 35. 1-5, 8. Olgaorlovella davydovi n. gen. n. sp. 1. Axial section. San Andres Fm. Sample SAR 11a-11. 2. Axial section. San Andres Fm. Sample SAR 11a-8 (already illustrated in Brose et al., 2013, figure 6. 12). 3. Subaxial section. San Andres Fm. Sample SAR 11a-15. 4. Axial section. San Andres Fm. Sample SAR 11a-14. 5. Axial section. San Andres Fm. Sample SAR 11a-3. 8. Axial section. San Andres Fm. Sample SAR 11-6. 6-7, 13. Orthovertellopsis calcitornellaeformis n. gen. n. sp. 6. Subtransverse section. San Andres Fm. Sample SAR 11a-16. 7. Transverse section. San Andres Fm. Sample SAR 11-16. 13. Oblique section. San Andres Fm. Sample SAR 11a-5. 9, 11, 14. Glomomidiella infrapermica n. sp. 9. Axial section showing the proloculus. San Andres Fm. Sample SAR 11-14. 11. Subtransverse section. Yeso Group. Sample MG(2) 10-7b. 14. Axial section relatively well preserved (dark wall). Yeso Group. Sample MG(2) 12-7. 10, 12. Orthovertellopsis protaeformis n. gen. n. sp. 10. Axial section. Yeso Group. Sample MG(2) 10-14. 12. Subaxial section. Yeso Group. Sample MG(2) 10-6. Scale bars equal $0.10 \mathrm{~mm}$. 
specimen is unique and the genus is still under discussion, a question mark is added to the name.

Occurrence. Early? Kungurian (late Leonardian) of New Mexico (San Andres Fm: sample MLY 1-1).

Nodosariata indet. cf. Dentalina cf. ninae Grozdilova

sensu Chuvashov, Dyupina, Mizeis and Chernykh, 1990

Figure 25.16

? 1990 Dentalina cf. ninae Grozdilova; Chuvashov, Dyupina, Mizeis and Chernykh, pl. 30, fig. 8.

v. 2013b Gen. indet.; Vachard, Krainer and Lucas, p. 348 (no illustration).

Description. Test ribbon-shaped to strongly elongate, with two rounded extremities. Very broad proloculus. Chambers semicircular. Measurements: $\mathrm{H}$ $=0.40 \mathrm{~mm} ; \mathrm{w}=0.14 \mathrm{~mm} ; \mathrm{w} / \mathrm{H}=0.34$; chambers: 5 ; $\mathrm{p}=0.08 \mathrm{~mm} ; \mathrm{h}=0.08 \mathrm{~mm} ; \mathrm{s}=0.01 \mathrm{~mm}$.

Occurrence. Late? Kungurian (latest Leonardian) of New Mexico (San Andres: sample SAR 11a-4).

Genus FRONDICULARIA Defrance in d'Orbigny, 1826 emend. Sellier de Civrieux and Dessauvagie, 1965

Type Species. Renulina complanata Defrance in de Blainville, 1824.

"Frondicularia" aff. turae Baryshnikov in

Baryshnikov, Zolotova, and Kosheleva, 1982

Figure 36.17

? 1982 Frondicularia turae Baryshnikov in Baryshnikov, Zolotova and Kosheleva, p. 33-34, pl. 9, figs. 2, 3.

? v. 2009 Frondicularia cf. turae Baryshnikov; Krainer, Lucas and Vachard, pl. 5, fig. 7, pl. 6, fig. 28.

v. 2013b Frondicularia aff. turae Baryshnikov; Vachard, Krainer and Lucas, p. 348 (no illustration).

Description. Measurements: $\mathrm{H}=0.42 \mathrm{~mm} ; \mathrm{w}=$ $0.17 \mathrm{~mm}$; $/ \mathrm{H}=0.40$; chambers: $4 ; \mathrm{h}=0.12 \mathrm{~mm}$; $\mathrm{s}$ $=0.01 \mathrm{~mm}$.

Remark. All the parameters of the species are a little smaller than those of our material.

Occurrence. Late Artinskian (Sarginian) of the Pre-Urals (Russia). Early? Kungurian (late Leonardian) of New Mexico (Yeso Group: sample MG 13f).

Family GEINITZINIDAE Bozorgnia, 1973

Genus GEINITZINA Spandel, 1901

Type Species. Geinitzina postcarbonica Spandel, 1901.
Occurrence. Latest Pennsylvanian or earliest Permian-latest Permian; cosmopolitan.

Geinitzina indepressa Cherdyntsev, 1914

Figure 25.8-25.9, 25.12-25.14

1914 Geinitzina indepressa Cherdyntsev, p. 26-27, pl. 1, fig. 9.

2000 Geinitzina indepressa Cherdyntsev; Groves, p. 300-301, pl. 5, figs. 1, 2, 3, 4, 5, 6 (with synonymy).

v. 2013b Geinitzina ex gr. postcarbonica Spandel Vachard, Krainer and Lucas, p. 348 (no illustration).

Description. Test straight triangular, moderately elongate. Chambers semisinushaped. $\mathrm{H}=(0.14)$ $0.16-0.45 \mathrm{~mm} ; \mathrm{w}=(0.07)-0.10-0.22 \mathrm{~mm} ; \mathrm{h}=$ (0.02)-0.03-0.06 mm; $\mathrm{s}=0.01 \mathrm{~mm}$. Proloculus spherical, a little prominent, $0.02-0.03 \mathrm{~mm}$ in diameter. Up to nine chambers, relatively short and high for the genus; moreover, the central depression is absent or very faint. Aperture terminal, central, simple, a little depressed.

Remarks. This species differs from G. postcarbonica in the shape of the chambers with a convex roof and not a centrally depressed one, and from $G$. spandeli plana Lipina, 1949, which is relatively similar, by more chambers and a smaller proloculus.

The material of Groves (2000) is remarkably similar to ours and proves the importance of this species for the stratigraphic and geographic correlations in North America.

Occurrence. Early Permian (sensu lato) of Russian Platform, Urals, and Xizang (China). Artinskian (early Leonardian) of Oklahoma (USA). Late? Kungurian (late Leonardian) of New Mexico (San Andres Fm: samples SAR 8a-7, SAR 8a-11, SAR 8a-14, SAR(2) 11-2, SAR 11-13, SAR 11a-10, SAR(2) 13-7, SAR(2) 13-10, SAR 18-1, SAR(2) 1911).

\section{CONCLUSIONS}

1. The algal microfloras described in this paper are poorly known in North and Central America. Therefore, the comparisons are difficult at the genus and/or species levels.

2. Hypothetically, a biostratigraphic zonation is proposed with six informal zones: 1) Boueina? crassundia and Gymnocodium? johnsonii Zone; 2) Gymnocodium? johnsonii Zone; 3) Ellesmerella rara and Gymnocodium? johnsonii Zone; 4) intercalation of the Glorieta sandstones barren of microfossils; 5) Boueina? tubulata Zone; and 6) Tubiphytes epim- 

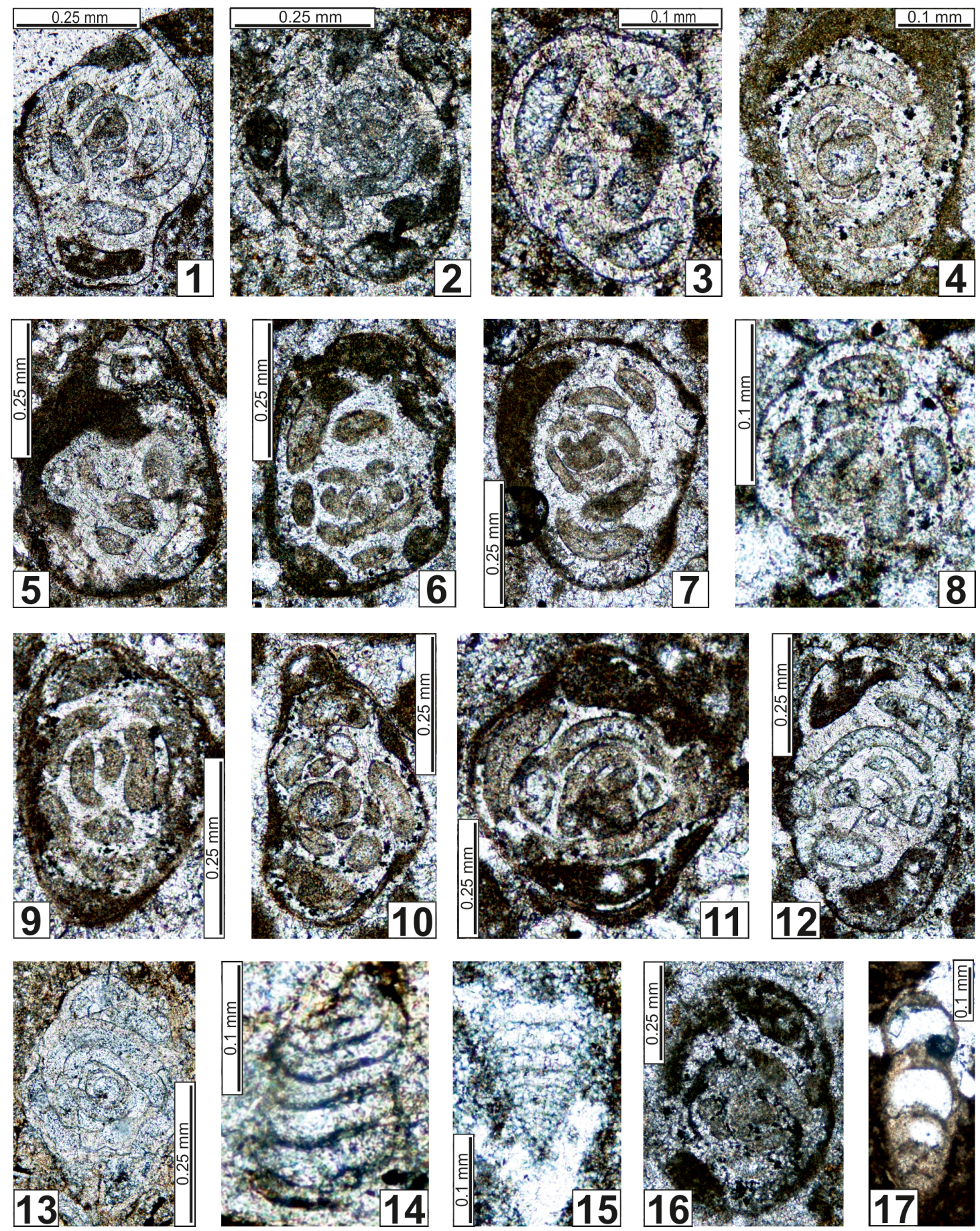

FIGURE 36. 1-12, 16. Glomomidiella infrapermica n. sp. 1. Axial section. Yeso Group. Sample MG(2) 10-9. 2. Subaxial section. San Andres Fm. Sample MLY(2) 5a-15. 3. Oblique subaxial section. Yeso Group. Sample MG(2) 10-8. 4. Subtransverse section. Yeso Group. Sample MG 10-7. 5. Broken subaxial section. Yeso Group. Sample MG(2) 10-10. 6. Subaxial section. Yeso Group. Sample MG(2) 10-4. 7. Axial section. Yeso Group. Sample MG(2) 10-5. 8. Oblique subaxial section. Yeso Group. Sample MG(2) 10-3. 9. Subaxial section. Yeso Group. Sample MG(2) 10-11. 10. Axial section. Yeso Group. Sample MG 10-7a. 11. Subtransverse section. Yeso Group. Sample MG(2) 10-7c. 12. Subaxial section. Yeso Group. Sample MG(2) 10-13 (already illustrated in Lucas et al., 2013b, figure 8I). 16. Poorly preserved subaxial section. San Andres Fm. Sample MLY 6-26. 13. Olgaorlovella davydovi n. gen. n. sp. Axial section. San Andres Fm. Sample SAR(2) 11-7. 14-15. Geinitzina indepressa Cherdyntsev, 1914. 14. Oblique subaxial section. San Andres Fm. Sample SAR(2) 11-2. 15. Subaxial section. San Andres Fm. Sample SAR(2) 19-1. 17. "Frondicularia" aff. turae Baryshnikov in Baryshnikov, Zolotova and Kosheleva, 1982. Axial section. Yeso Group. Sample MG 13f. 
onellaeformis Zone.

3. Biostratigraphically, the most characteristic taxa seem to be Ellesmerella rara $\mathrm{n}$. $\mathrm{sp}$. for the early? Kungurian; Boueina? tubulata $\mathrm{n}$. $\mathrm{sp}$. for the middle? Kungurian; and Gymnocodium? bacillum $\mathrm{n}$. sp. and Tubiphytes epimonellaeformis $\mathrm{n}$. sp. for the late? Kungurian.

4. This microflora is interesting for the knowledge of some palaeobotanical orders and classes: codiaceans, gymnocodiaceans; as well as for the discussion of these possible cyanobacterial/foraminiferal consortia, the Tubiphytidae. The codiaceans, always rare in the Carboniferous-Permian, are exceptionally abundant in the Kungurian deposits of $\mathrm{New}$ Mexico with a relatively abundant Boueina?, which permits adjustment of the phylogeny of this group during the late Early Permian. Boueina?, even if it is not exactly the ancestor of the gymnocodiaceans, probably provides a good image of this ancestor. Eventually, Boueina? might be the ancestor of Gymnocodium?, whereas Permocalculus evolved earlier from another branch of this lineage; also appeared in North America and not in Tethys.

5. The gymnocodiaceans are well represented in our material with two new primitive species; relatively difficult to classify, because their conceptacles have not been observed.

6. The dasycladales are very rare in the Kungurian of New Mexico, and consequently, less well represented than in Tethys. In particular, the epimastoporaceans have disappeared from North America, but remained common during the same epoch in the Tethyan shelves, in particular in the Carnic Alps. Only an undetermined Chlorophyta has been found which may have some affinities with the dasycladales, but might also be an atypical taphonomic stage of codiacean algae.

7. There are rare specimens of a new species of Ellesmerella. The ellesmerellids are very rare in the Kungurian of New Mexico; especially, the complex biopisolites of the Late Pennsylvanian-earliest Permian disappeared. This point is apparently unrelated to the supposed Artinskian-Kungurian warming of the seas.

8. The Tubiphytidae present locally a diversification, which is apparently absent in Tethys; that will give rise to Epimonella, present in both parts of the world. They are represented by a new species Tubiphytes epimonellaeformis $\mathrm{n}$. sp., which confirms the double affinity, botani- cal and animal, but does not permit us to formulate a new explanatory hypothesis about this very puzzling group. It would be useful to restudy the affinities between Palaeonubeculata (sic) fluxiformis and Tubiphytes epimonellaeformis $\mathrm{n}$. sp. and the value of both taxa as Kungurian biomarkers.

9. The Tuberitinidae are present everywhere, but not very diversified.

10. These microfloras are endemic and do not provide data for palaeobiogeographic correlations.

11. The foraminiferal microfaunas described in this paper are poorly known in North and Central America. Therefore, the comparisons are difficult at the generic and/or specific levels.

12. Two new species of dark-microgranular walled Globivalvulina are described: G. parapiciformis $\mathrm{n}$. $\mathrm{sp}$. and $\mathrm{G}$. retroseptata $\mathrm{n}$. $\mathrm{sp}$.

13. Two new species of atypical Globivalvulina (i.e, with a sporadic inner pseudofibrous layer in the wall) are also created: G. novamexicana n. sp. and G. praegraeca n. sp.

14. The Miliolata are primitive taxa: Hemigordiellina, Ammovertella, Pseudospira, Palaeonubecularia, and Hemigordius, as well as some taxa newly appeared: Glomomidiella already described, and Olgaorlovella n. gen., Orthovertellopsis n. gen., and Praeneodiscus n. gen.

15. These new taxa are important for understanding the beginning of the differentiation of various lineages of Permian Miliolata.

16. These new taxa might permit a more accurate biozonation of the Leonardian regional stage of Northern America, especially of the Yeso Group and San Andres Formation in New Mexico.

17. The principal biomarkers seem to be the four new species of Globivalvulina, Olgaorlovella davydovi n. gen. et sp., Glomomidiella infrapermica n. sp., Praeneodiscus convexus n. gen. et sp., Nodosariata gen. indet., Nestellorella? sp., and "Frondicularia" aff. turae.

18. The assemblages are characteristic of the Artinskian-Kungurian, but each stage of this period is difficult to characterise separately.

19. Despite their general endemism, some foraminifers might be used for accurate correlations with the stratotypes of the Urals (Russia): Globivalvulina apiciformis; G. donbassica; Hemigordius saranensis; Nodosinel- 
loides longa; and Geinitzina indepressa.

20. A biostratigraphic zonation by means of smaller foraminifers is proposed with six zones: 1) Glomomidiella infrapermica n. sp. and Orthovertellopsis protaeformis $\mathrm{n}$. $\mathrm{sp}$. Zone; 2) Globivalvulina parapiciformis $\mathrm{n}$. sp. and Nestellorella? sp. Zone; 3) "Frondicularia" aff. turae Zone; 4) intercalation of the Glorieta sandstones barren of microfossils; 5) Praeneodiscus convexus $\mathrm{n}$. gen. et $\mathrm{sp}$ and Orthovertellopsis calcitornellaeformis $\mathrm{n}$. gen. et $\mathrm{sp}$. Zone; and 6) Olgaorlovella davydovi n. gen. et sp. Zone.

\section{ACKNOWLEDGEMENTS}

Thanks to J. Walraff (Innsbruck) for preparing thin sections, and T. Vachard, S. Clausen, D. Decroocq, and L. Devaere (Villeneuve d'Ascq) for technical help. Our access to outcrops in the Fra Cristobal Mountains and the Armendaris Ranch was made possible by T. Waddell. Field assistance was provided by R. Brose and J. Spielmann. Thanks to G. Nestell (Arlington) and B. Granier (Brest) for their reviews and suggestions; and to the editorial staff of PEMSATS $(H$. Mallison, $S$. Gerber, K. Black, and J. Pattison Rumford) for their judicious advice.

\section{REFERENCES}

Aizenverg, D.E., Astakhova, T.V., Berchenko, O.I., Brazhnikova, N.E., Vdovenko, M.V., Dunaeva, N.N., Zernetskaya, N.V., Poletaev, V.I., and Sergeeva, M.T. 1983. Verkhneserpukhovskii podyarus Donetskogo basseina. Akademiya Nauk Ukrainskoi SSR, Institut Geologicheskii Nauk:1-164. (In Russian)

Akopian, V.T. 1974. Atlas of the Fossil Fauna from Armenia SSR. Akademiya Nauk Armenia SSR, Institut Geologicheskykh Nauk, Erevan. (In Russian)

Alipour, Z., Hosseini-Nezhad, S.M., Vachard, D., and Rashidi, K. 2013. Biostratigraphy and description of smaller foraminifers of Dorud Group (uppermost Gzhelian-lower Sakmarian) in Tang-e Shamshirbor section Eastern Alborz, Iran. Geological Journal, 48:385-402.

Altermann, W., Kazmierczak, J., Oren, A., and Wright, D.T. 2006. Cyanobacterial calcification and its rockbuilding potential during 3.5 billion years of Earth history. Geobiology, 4:147-166.

Altiner, D., 1978. Trois nouvelles espèces du genre Hemigordius (Foraminifère) du Permien supérieur de Turquie (Taurus oriental). Notes du Laboratoire de Paléontologie de I'Université de Genève, 2:27-30.
Anfimov, L.V., Chuvashov, B.I., Grifer, B.I., Gusev, A.K, Kocklin, A.I., Muravyev, I.S., Sofronitsky, P.A., and Zolotova, V.P. 1991. General characteristics of Permian deposits of the Urals and Povolzhye, p. A1-A44. In Chuvashov, B.I. and Nairn, A.E.M. (eds.), Permian System of the World. Field Excursion Guides, JulyAugust, 1991, Library Earth Sciences \& Resources Institute, University of South Carolina, Columbia, South Carolina.

Armstrong, A.K. and Mamet, B.L. 1977. Carboniferous microfacies, microfossils, and corals, Lisburne Group, Arctic Alaska. United States Geological Survey Professional Paper, 849:1-144.

Baars, D.L. 1992. Kansaphyllum, a new Late Pennsylvanian phylloid algal genus. Journal of Paleontology, 66:697-701.

Baryshnikov, V.V., Zolotova, V.P., and Kosheleva, B.F. 1982. Novye vidy foraminifer artinskogo yarusa permskogo Priuralya. Akademiya Nauk SSSR, Uralskii Nauchnyi Tsentr, Institut Geologii i Geokhimii, Preprint:1-54. (In Russian)

Bassoullet, J.P., Bernier, P., Génot, P., Poncet, J., and Roux, A. 1983. Les algues Udotéacées du Paléozoïque au Cénozoïque. Bulletin des Centres de Recherche Exploration-Production Elf-Aquitaine, 7:454-621.

Berczi-Makk, A. 1978. Tengeri felsöperm üledékek Budapesttöl DK-re a Sári-2. Sz. Szénhidrogénkutató fúrásban Földtani Közlöny. Bulletin of the Hungarian Geological Society, 108:313-327.

Berczi-Makk, A., Csontos, L., and Pelikán, P. 1995. Data on the Upper Permian foraminifer fauna of the Nagyvisnyó Limestone formation from borehole Mályinka-8 (Northern Hungary). Acta Geologica Hungarica, 38:185-250.

Berczi-Makk, A. and Kochansky-Devidé, V. 1981. Marine Lower and Middle Permian in the oil explanatory well Ujfalu-I (SW-Hungary). Acta Geologica Academiae Scientiarum Hungaricae, 24:117-128.

Bernier, P. 1984. Les formations carbonatées du Kimméridgien et du Portlandien dans le Jura méridional, stratigraphie, micropaléontologie et sédimentologie. Documents des Laboratoires de Géologie de Lyon, 92:1-73.

Bessey, C.E. 1907. A synopsis of plant phyla. University Studies of the University of Nebraska, 7:275-373.

Bilgütay, U. 1959. The Permian calcareous algae from southeastern Anatolia. Bulletin of the Mineral Research and Exploration, 52:48-58.

Blazejowski, B. 2009. Foraminifers from the Treskelodden Formation (Carboniferous-Permian) of south Spitsbergen. Polish Polar Research, 30:193-230.

Bogush, O.I. 1963. Foraminifery $i$ stratigrafiya srednego $i$ verkhnego karbona vostochnoy chasti Alayskogo Khrebta. Akademiya Nauk SSSR, Sibirskoe Otdelenie, Institut Geologi i Geofiziki, Trudy: 1-132. (In Russian) 
Bornet, É. and Flahault, C. 1886. Révision des Nostocacées hétérocystées contenues dans les principaux herbiers de France. Annales des Sciences Naturelles, Botanique, septième série, 7:177-262.

Bozorgnia, F. 1973. Paleozoic foraminiferal biostratigraphy of central and east Alborz Mountains, Iran. National Iranian Oil Company, Geological Laboratories, Publication, 4:1-185.

Brady, H.B. 1876. A monograph of Carboniferous and Permian foraminifera (the genus Fusulina excepted). Palaeontographical Society of London, 30:1-166.

Brady, H.B. 1884. Report of the foraminifera dredged by H.M.S. Challenger during the years 1873-1876. Reports on the Scientific Results of the Exploratory Voyage of the H.M.S. Challenger, Zoology, 9:1-814.

Brazhnikova, N.E. and Potievska, P.D., 1948. Naslidki vivcheniya foraminifer za materiyalami sverdlovin zakhidnoi okrain Donbasu. Akademiya Nauk Ukrainskoi SSR, Institut Geologicheskii Nauk, serii stratigrafii i paleontologii, 1(2):76-103. (In Ukrainian)

Brenckle, P.L. 2005. A compendium of Upper DevonianCarboniferous type foraminifers from the former Soviet Union. Cushman Foundation for Foraminiferal Research, Special Publication, 38:1-153.

Brenckle, P.L., Baesemann, J.F., Lane, H.R., West, R.R., Webster, G.D., Langenheim, R.L., Briand, U., and Richards B.C. 1997. Arrow Canyon, the Mid-Carboniferous boundary stratotype. Cushman Foundation for Foraminiferal Research, Supplement to Special Publication 38:13-32.

Brose, R.J., Lucas, S.G., and Krainer, K. 2013. Permian San Andres Formation in central and western New Mexico. New Mexico Museum of Natural History and Science, Bulletin, 59:213-226.

Browne, R.G. and Pohl, E.R. 1973. Stratigraphy and genera of calcareous Foraminifera of the Fraileys facies (Missississippian) of central Kentucky. Bulletins of American Paleontology, 64:173-243.

Bucur, I.I. 1994. Lower Cretaceous Halimedaceae and Gymnocodiaceae from southern Carpathians and Apuseni Mountains (Romania) and the systematic position of the Gymnocodiaceae. Beiträge Paläontologie, 19:13-37.

Buitrón-Sanchez, B.E., Vachard D., Almazan-Vazquez, E., and Palafox, J.J. 2012. Una secuencia cratónica completa del Carbonífero al Pérmico Inferior expuesta en los cerros El Tule, noreste de Sonora, México. Revista de Ciencias Geológicas, 29:39-62.

Bykova, E.V. and Polenova, E.N. 1955. Foraminifery, radiolarii $i$ ostrakody Devona Volgo-Uralskoi oblasti. Trudy VNIGRI, 87:1-141. (In Russian; French translation, C.E.D.P. $n^{\circ} 1603$, BRGM:1-154).

Calkins, G.N. 1926. The Biology of the Protozoa. Lea and Febiger, Philadelphia.

Cavalier-Smith, T. 2002. The phagotrophic origin of eukaryotes and phylogenetic classification of Protozoa. International Journal of Systematic and Evolutionary Microbiology, 52:297-354.
Cavalier-Smith, T. 2003. Protists phylogeny and the highlevel classification of Protozoa. European Journal of Protistology, 39:338-348.

Cherdyntsev, W. 1914. K faune foraminifer permskikh otlozhenii vostochnoi polosy Evropeiskoi Rossii. Trudy Obshchestva Estestvoispytateley pri Imperatorskomy Kazanskomy Universitety, 46:3-88. (In Russian)

Chuvashov, B.I. 1973. Novye devonskie vodorosli Urala. Akademiya Nauk SSSR, Ural Nauchnyi Tsentr, Trudy Instituta Geologii i Geokhimii, 99:28-42. (In Russian)

Chuvashov, B.I. 1983. Permian reefs of the Urals. Facies, 8:191-212.

Chuvashov, B.I., Dyupina, G.V., Mizeis, G.A., and Chernykh, V.V. 1990. Opornye razrezy verkhnego karbona $i$ nizhnei permi zapadnogo sklona Urala $i$ Priuralya. Akademiya Nauk SSSR, Uralskoie Otdelenie: 1-369. (In Russian)

Chuvashov, B.I., Luchinina, V.A., Shuysky, V.P., Shaikin, I.M., Berchenko, O.I., Ishchenko, A.A., Saltovskaya, V.D., and Shirshova, D.I. 1987. Iskopaemye izvestkovye vodorosli, morfologiya, sistematika, metody izucheniya. Akademiya Nauk SSSR, Sibirskoe Otdelenie, Trudy Instituta Geologii i Geofiziki, 674:5224. (In Russian)

Chuvashov, B.I., Shuysky, V.P., and Ivanova R.M. 1993. Stratigraphical and facies complexes of the Paleozoic calcareous algae of the Urals, p. 93-119. In Barattolo, F., De Castro, P., and Parente, M. (eds.), Studies on Fossil Benthic Algae. Bolletino della Societá Paleontologica Italiana, Special Volume, Modena.

Chuvashov, B.I., Yuferev, O.V., and Liuchinina, V.A. 1985. Vodorosli sredngo $i$ verkhnego devona zapadnoi Sibiri i Urala. Akademiya Nauk SSSR, Sibirskoe Otdelenie, Trudy Instituta Geologii i Geofiziki, 619:72-99. (In Russian)

Conil, R., Groessens, E., and Lys, M. 1977. Etude micropaléontologique de la tranchée d'Yves-Gomezée ( $T n$ 3c-V 1-V 2, Belgique). Bulletin de la Société belge de Géologie, 82 (dated 1973):201-239.

Conil, R., Longerstaey P.J., and Ramsbottom, W.H.C. 1980. Matériaux pour l'étude micropaléontologique du Dinantien de Grande-Bretagne. Mémoires de l'Institut Géologique de l'Université de Louvain, 30 (dated 1979):1-115.

Conil, R. and Pirlet, H. 1970. Le calcaire carbonifère du synclinorium de Dinant et le sommet du Famennien. Colloque sur la stratigraphie du Carbonifère. Congrès et Colloques de l'Université de Liège, 55:47-63.

Corrochano, D., Vachard, D., and Armenteros, I. 2013. New insights on the red alga Archaeolithophyllum and its preservation from the Pennsylvanian of the Cantabrian Zone (NW Spain). Facies, 59:949-967. doi:10.1007/s10347-012-0347-8

Cózar, P. and Somerville, I.D. 2012. Mississippian Biseriamminaceae and their evolutionary development. Journal of Foraminiferal Research, 42:216-233. 
Crescenti, U. 1969. Biostratigrafia delle facies mesozoiche dell'Appennino centrale. Geologica Romana, 8:15-40.

Crespin, I. 1958. Permian Foraminifera of Australia. Commonwealth of Australia, Department of National Development, Bureau of Mineral Resources, Geology and Geophysics, 48:1-207.

Cushman, J.A. 1928. Additional genera of the Foraminifera. Contributions from the Cushman Laboratory for Foraminiferal Research, 4:1-8.

Cushman, J.A. 1930. Note sur quelques foraminifères jurassiques d'Auberville (Calvados). Bulletin de la Société linnéenne de Normandie, 8:132-135.

Cushman, J.A. and Waters, J.A. 1927. Pennsylvanian Foraminifera from Michigan. Contributions from the Cushman Laboratory for Foraminiferal Research, 3:107-110.

Cushman, J.A. and Waters, J.A. 1928a. Some Foraminifera from the Pennsylvanian and Permian of Texas. Contributions from the Cushman Laboratory for Foraminiferal Research, 4:31-55.

Cushman, J.A. and Waters, J.A. 1928b. Additional Cisco Foraminifera from Texas. Contributions from the Cushman Laboratory for Foraminiferal Research, 4:62-67.

Cushman, J.A. and Waters, J.A. 1930. Foraminifera of the Cisco Group. Bulletin University of Texas, 3019:22-81.

Davydov, V.I. 1996. Fusulinid biostratigraphy and the correlation of Moscovian-Guadalupian North American, Tethyan and Boreal (Russian Platform/Uralian) standards. Permophiles, 29:47-52.

Davydov, V.I., Krainer, K., and Chernykh, V. 2013. Fusulinid biostratigraphy of the Lower Permian Zweikofel Formation (Rattendorf Group; Carnic Alps, Austria) and Lower Permian Tethyan chronostratigraphy. Geological Journal, 48:57-100.

Davydov, V.I., Walter, S., and Spinosa, C. 1997. Permian foraminiferal biostratigraphy and sequence stratigraphy of Nevada. Cushman Foundation for Foraminiferal Research, Special Publication, 38:31-34.

Dawson, W.C. 1992. Phylloid algal microstructures enhanced by epifluorescence petrography. Journal of Paleontology, 66:523-525.

de Blainville, H.M. 1824. Dictionnaire des Sciences Naturelles, Mollus-Morf. F.G. Levrault, Paris.

Deleau, P. and Marie, P. 1961. Les Fusulinidés du Westphalien $\mathrm{C}$ du bassin d'Abadla et quelques autres foraminifères du Carbonifère algérien. Publications $d u$ Service de la Carte Géologique d'Algérie, 25:45-160.

Derville, H. 1952. A propos de Calcisphères (rectification). Comptes Rendus Sommaires de la Société Géologique de France, 6:236-237.

d'Orbigny, A. 1826. Tableau méthodique de la classe des Céphalopodes. Annales des Sciences Naturelles, 7:245-314.

Dragastan, O. 2008. Mesozoic and Cenozoic calcareous algae, praecursors of family Codiaceae. Acta Palaeontologica Romaniae, 6:83-95.
Dunbar, C.O., Baker, A.A., Cooper, G.A., King, P.H., McKee, E.D., Miller, A.K., Moore, R.C., Newell, N.D., Romer, A.S., Sellards, E.H., Skinner, J.W., Thomas, H.R., and Wheeler, H.E. 1960. Correlation of the Permian formations of North America. Bulletin of the Geological Society of America, 71:1763-1806.

Dunbar, C.O. and Skinner, J.W. 1937. Permian Fusulinidae of Texas. In The geology of Texas. The University of Texas Bulletin, 3701(3):518-825.

Elias, M.K. 1959. Review of "Facies of Upper Carboniferous and Artinskian deposits in the Sterlitamak Ishimbaevo region...". International Geology Review, 1:3988.

Elliott, G.F. 1955. The Permian calcareous alga Gymnocodium. Micropaleontology, 1:83-90.

Elliott, G.F. 1957. New calcareous algae from the Arabian Peninsula. Micropaleontology, 3:227-230.

Elliott, G.F. 1962. More microproblematica from the Middle East. Micropaleontology, 8:29-44.

Elliott, G.F. 1970. New and little-known Permian and Cretaceous Codiaceae (calcareous algae) from the Middle East. Palaeontology, 13:327-333.

Elliott, G.F. 1982. A new calcareous alga from the Middle Jurassic of England: its relationships and evolutionary position. Palaeontology, 25:431-437.

El-Nakhal, H.A.A. 1983. Agglutinella, a new miliolid genus Foraminiferida. Journal of Foraminiferal Research, 13:129-133.

Endo, R. 1959. Stratigraphical and paleontological studies of the later Paleozoic calcareous algae in Japan. XIV. Fossil algae from the Nyugawa Valley in the Hida Masssif. Science Reports of the Saitama University, series $\mathrm{B}, 3: 177-207$.

Endo, R. 1969. Fossil algae from the Khao Phlong Phrab District in Thailand. Geology and Paleontology of Southeast Asia, 7:33-85.

Endo, R. and Kanuma M., 1954. Stratigraphical and paleontological studies of the later Paleozoic calcareous algae in Japan; VII. Geology of the Mino mountainland and southern part of Hida plateau with description of the algal remains found in those districts. Science Reports of the Saitama University, series $B, 1: 177-205$.

Fichten, W.M., Starcher, M.A., Buffler, R.T., and Wilde, G.L., 1995. Sequence stratigraphic framework of Lower Permian carbonate platform margins, Sierra Diablo, West Texas, p. 23-66. In Garber, R.A. and Lindsay, R.F. (eds.), Wolfcampian-Leonardian shelf margin facies of the Sierra Diablo-seismic scale model for subsurface exploration. 1995 Annual Field Trip Guidebook, West Texas Geological Society, Midland.

Filimonova, T.V. 2008. Smaller Foraminifers from type sections of the Bolorian Stage, the Lower Permian of Darvaz. Stratigraphy and Geological Correlation, 16:22-41.

Filimonova, T.V. 2010. Smaller foraminifers of the Lower Permian from Western Tethys. Stratigraphy and Geological Correlation, 18:687-811. 
Flügel, E. 1966. Algen aus dem Perm der Karnischen Alpen. Carinthia II, Sonderheft, 25:3-76.

Flügel, E. 1988. Halimeda: palaeontological record and palaeoenvironmental significance. Coral Reefs, 6:123-130.

Flügel, E. 2004. Microfacies of carbonate rocks, analysis, interpretation and application. Springer Publisher, Heidelberg, Dordrecht, London, New York.

Flügel, E., Kochansky-Devidé, V., and Ramovs, A. 1984. A Middle Permian calcisponge/algal/cement reef: Straza near Bled, Slovenia. Facies, 10:179-256.

Forsythe, T.W., Wood, R., and Dickson, J.A.D. 2002. Mass spawning in ancient reef communities: evidence from Late Paleozoic phylloid algae. Palaios, 17:615-621.

Foster, C.B., Palmieri, V., and Fleming, P.J.G. 1985. Plant microfossils, Foraminiferida, and Ostracoda, from the Fossil Cliff Formation (Early Permian, Sakmarian), Perth Basin, Western Australia. Special Publications South Australia Department Mines and Energy, 5:61-105.

Fritsch, F.E. 1945. The structure and reproduction of the Algae. Cambridge University Press, Cambridge.

Fursenko, A.V. 1958. Osnovnye etapy razvitiya faun foraminifer $v$ geologicheskom prohlom. Trudy Instituta Geologicheskikh Nauk, Akademiya Nauk Beloruskoi SSR, 1:10-29. (In Russian)

Gaillot, J. and Vachard, D. 2007. The Khuff Formation (Middle East) and time equivalents in Turkey and South China: biostratigraphy from Capitanian to Changhsingian times (Permian), new foraminiferal taxa, and palaeogeographical implications. Coloquios de Paleontología, 57:37-223.

Gargouri, S. and Vachard, D. 1988. Sur Hemigordiopsis et d'autres foraminifères porcelanés du Murghabien du Tebaga (Permien supérieur de Tunisie). Revue de Paléobiologie, Special volume 2, Benthos'86, 1:5768.

Gerke, A.A. 1952. Microfauna permskikh otlozhenii Nordvikskogo raiona $i$ ee stratigrafickeskoe znachenie. Nauchno-Issledovatel'skii Institut Geologii Arktiki (NIIGA), Trudy 28:1-209. (In Russian)

Gerke, A.A. 1959. O novom rode permskikh nodosarievidnykh foraminifer $i$ utochnenii kharakteristiki roda Nodosaria. Sbornik Statey po paleontologii i biostratigrafii, Nauchno-Issledovatel'skii Institut Geologii Arktiki (NIIGA), 17:41-59. (In Russian)

Gerke, A.A. 1967. O morfologicheskikh priznakakh dvusimmetrichnykh nodozariid (foraminifery) $i$ soderzhanii vidovykh opisany. Uchenye Zapiski NIIGA, paleontologiya i biostratigrafiya, 19:5-34. (In Russian)

Gorsky, V.P. and Kalmykova, M.A 1986. Atlas kharakternykh kompleksov permskoi fauny i flori Urala $i$ Russkoi Platformy. Trudy VSEGEI, 331:1-328. (In Russian)

Granier, B. 2012. The contribution of calcareous green algae to the production of limestones: a review. Geodiversitas, 34:35-60. doi:10.5252/g2012n1a3
Griffith, J.W. and Henfrey, A. 1875. The Micrographic Dictionary, 1, (third edition). van Voorst, London.

Groves, J.R. 1984. Biostratigraphic significance of Hemigordius harltoni Cushman and Waters, 1928 (Foraminiferida). Journal of Paleontology, 58:78-81.

Groves, J.R. 1988. Calcareous foraminifers from the Bashkirian stratotype (Middle Carboniferous, South Urals) and their significance for intercontinental correlations and the evolution of the Fusulinidae. Journal of Paleontology, 62:368-399.

Groves, J.R. 2000. Suborder Lagenina and other smaller foraminifers from uppermost Pennsylvanian-Lower Permian rocks of Kansas and Oklahoma. Micropaleontology, 46:285-326.

Groves, J.R. and Boardman, H. 1999. Calcareous smaller foraminifers from the lower Permian Council Grove Group near Hooser, Kansas. Journal of Foraminiferal Research, 29:243-262.

Groves, J.R. and Wahlman, G.P. 1997. Biostratigraphy and evolution of Late Carboniferous and Early Permian smaller foraminifers from the Barents Sea (offshore Arctic Norway). Journal of Paleontology, 71:758-779.

Grozdilova, L.P. 1956. Miliolidy verkhneartinskikh otlozhenii nizhnei Permi zapadnogo sklona Urala. Trudy VNIGRI, 98, Mikrofauna SSSR, 8:521-528. (In Russian)

Gu, S., Feng, Q., and He, W. 2005. The last Permian deep-water fauna: Latest Changhsingian small foraminifers from southwestern Guangxi, South China. Micropaleontology, 53:311-330.

Güvenç, T. 1965. Etude stratigraphique et micropaléontologique du Carbonifère et du Permien des Taurus occidentaux dans l'arrière-pays d'Alanya (Turquie). Unpublished $\mathrm{PhD}$ thesis, Université de Paris.

Güvenç, T. 1966. Description de quelques espèces d'algues calcaires (Gymnocodiacées et Dasycladacées) du Carbonifère et du Permien des Taurus occidentaux (Turquie). Revue de Micropaléontologie, 9:94-103.

Hance, L., Hou, H.F., and Vachard, D. 2011. Upper Famennian to Visean foraminifers and some carbonate microproblematica from South China, Hunan, Guangxi and Guizhou. Geological Science Press, Beijing.

Harlton, B.H. 1928. Pennsylvanian Foraminifera of Oklahoma and Texas. Journal of Paleontology, 1:305-311.

Harris, A.G., Brenckle, P.L., Baesemann, J.F., Krumhardt, A.P., and Gruzlovic, P.D. 1997. Comparison of conodont and calcareous microfossil biostratigraphy and lithostratigraphy of the Lisburne Group (Carboniferous), Sadlerochit Mountains, Northeast Brooks Range, Alaska, p. 195-219. In Dumoulin, J.A. and Gray, J.E. (eds.), Geologic studies in Alaska by the U.S. Geological Survey, 1995. U.S. Geological Survey Professional Paper, Washington. 
Henbest, L.G. 1963. Biology, mineralogy, and diagenesis of some typical late Paleozoic sedimentary foraminifera and algal-foraminiferal colonies. Cushman Foundation for Foraminiferal Research, Special Publication 6:1-44.

Henderson, C.M., Davydov, V.I., and Wardlaw, B.R. (contributors: Gradstein F.M., Hammer, O.) 2012. The Permian Period, p. 653-679. In Gradstein, F.M., Ogg, J.G., Schmitz, M.D., and Ogg, G.M. (eds.), The Geologic Time Scale 2012. Elsevier Publisher, Amsterdam.

Ho, J. 1959. Triassic Foraminifera from the Chialingchiang Limestone of South Szechuan. Acta Paleontologica Sinica, 7:387-418.

Hohenegger, J. 1997. Morphological niches as tools for phylogenetic analysis: Permian and Triassic Lagenina as a case study. Cushman Foundation for Foraminiferal Research Special Publication, 38:63-69.

Homann, W. 1972. Unter- und tief-mittelpermische Kalkalgen aus den Rattendorfer Schichten, dem Trogkofel-Kalk und dem Treßdorfer Kalk der Kanischen Alpen (Österreich). Senckenbergiana Lethaia, 53:135-313.

Howchin, W. 1895. Carboniferous foraminifera of Western Australia, with descriptions of new species. Transactions and Proceedings of the Royal Societies of South Australia, 19:198-200.

Hubmann, B. 1990. Udoteaceen (Grünalgen) aus dem Grazer Paläozoikum/Österreich (Barrandenkalke, Eifelium). Facies, 22:147-158.

Igonin, V.M. 1998. New species of foraminifers from the Lower-Upper Permian Boundary Beds in the Pechora Coal Basin. Paleontologicheskii Zhurnal, 1998(2):19-29. (In Russian)

Jenny, J. and Jenny-Deshusses, C. 1978. Dorudia dorudensis n. gen., n. sp., et les Tuberitininae du Permien de l'Elbourz oriental en Iran. Note du Laboratoire de Paléontologie de l'Université de Genève, 2:7-15

Johnson, J.H. 1946. Lime-secreting algae from the Pennsylvanian and Permian of Kansas. Geological Society of America Bulletin, 57:1080-1120.

Johnson, J.H. 1956. Archaeolithophyllum, a new genus of Paleozoic coralline algae. Journal of Paleontology, 30:53-55.

Johnson, J.H. and Kaska, H.V. 1965. Fossil algae from Guatemala. Professional Contributions Colorado School Mines, 1:1-152.

Karavaeva, N.I. and Nestell, G.P. 2007. Permian foraminifers of the Omolon Massif, northeastern Siberia, Russia. Micropaleontology, 53:161-211.

Khvorova, I.V. 1946. On new genus of algae from the Middle Carboniferous deposits of the Moscow Basin. Doklady Akademii Nauk SSSR, 53:737-739. (English translation from Russian)
Khvorova, I.V. 1951. Bioherms of foraminifers in the reefal massifs of the Ichimbaev Pre-Urals. Doklady Akademii Nauk SSSR, 78:1193-1194. (In Russian, French translation by Pietersson de Saint Aubin 374:1-3)

Kirkland, B.L., Moore, C.H.J., and Dickson, J.A.D. 1991. Aragonitic Pennsylvanian phylloid algae from New Mexico: the missing link. American Association of Petroleum Geologists Bulletin, 75(D3):610.

Kirkland, B.L., Moore, C.H.J., and Dickson, J.A.D. 1993. Well preserved, aragonitic phylloid algae (Eugonophyllum, Udoteacea) from the Pennsylvanian Holder Formation, Sacramento Mountains, New Mexico. Palaios, 8:111-120.

Kobayashi, F. 1997. Upper Permian foraminifers from the Iwai-Kanyo area, West Tokyo, Japan. Journal of Foraminiferal Research, 27:186-195.

Kobayashi, F. 2001. Faunal analysis of Permian foraminifers of the Kuma Formation in the Kurosegawa Belt of west Kyushu, Southwest Japan. News of Osaka Micropaleontologists, special volume, 12:61-77.

Kobayashi, F. 2004. Late Permian foraminifers from the limestone block in the southern Chichibu Terrane of west Shikoku, SW Japan. Journal of Paleontology, 78:62-70.

Kobayashi, F. 2006. Middle Permian foraminifers of the Izuru and Nabeyama formations in the Kuzu area, central Japan. Part 2. Schubertellid and ozawainellid fusulinoideans, and non-fusulinoidean foraminifers. Paleontological Research, 10:61-77.

Kobayashi, F. 2007. Foraminiferal fauna and lithofacies of Middle Permian limestone blocks in the middle course of Kuma River (Osakama), southern margin of the Chichibu Terrane in west Kyushu, Japan. Paleontological Research, 11:337-347.

Kobayashi, F. 2012. Middle and Late Permian foraminifers from the Chichibu Belt, Takachiho area, Kyushu, Japan: implications for faunal events. Journal of Paleontology, 86:669-687.

Kochansky-Devidé, V. 1970. Permski mikrofosili zahodnih Karavank. Geologija, Razprave in Porocila, 13:175-256.

Kochansky-Devidé, V. 1973. Ramovsia limes n. g., n. sp., (Problematica, ein Leitfossil der Grenzlandbänke (Unteres Perm). Neues Jahrbuch für Geologie, Paläontologie Monathefte, 8:462-468.

Kochansky-Devidé, V. and Sliskovic, T. 1969. Gornjopermski Mikrofosili Han Orahovice i Suljaca u Bosni s osobitim obzirom na algu Permocalculus fragilis. Geoloski Vjesnik, Instituta za Geoloska istrazivanja u Zagrebu, 22: 105-110.

Kolodka, C., Vennin, E., Vachard, D., Trocmé, V., and Goodarzi, M. 2012. Timing and progression of the end-Guadalupian crisis in the Fars province (Dalan Formation, Kuh-e Gakhum, Iran) constrained by foraminifers and other carbonate microfossils. Facies, 58:131-153. 
Konishi, K. 1955. Succodium, a new codiacean genus, and its algal associates in the Late Permian Kuma Formation of southern Kyushu, Japan. Tokyo University, Faculty of Sciences, 2:225-240.

Konishi, K. and Wray, J.L. 1961. Eugonophyllum, a new Pennsylvanian and Permian genus. Journal of Paleontology, 35:659-666.

Konovalova, M.V. 1962. Novye pozdnekamennougol'nye i rannepermskie fuzulinidy Timano-Pechorskoj provintsii (New Late Carboniferous and Early Permian fusulinids of the Timan-Pechora Province). Paleontologicheskii Zhurnal, 1962(1):47-57. (In Russian)

Kotlyar, G.V., Zakharov, Yu.D., Kropacheva, G.S., Pronina, G.P., Chediya, I.O., and Burago, V.I. 1989. Pozdnepermskii etap evolyutsii organicheskogo mira, Midinskii yarus SSSR (Late Permian steps in the evolution of the organic world, Midian stage of the USSR). Leningrad "Nauka", Leningradskoe Otdelenie. (In Russian)

Kottlowski, F.E., Flower, R.H., Thompson, M.L., and Foster, R.W. 1956. Stratigraphic studies of the San Andres Mountains, New Mexico. New Mexico Bureau of Mines and Mineral Resources, Memoir, Socorro.

Kozlowski, R. and Kazmierczak, J. 1968. On two Ordovician calcareous algae. Acta Palaeontologica Polonica, 13:325-346.

Krainer, K., Lucas, S.G., and Brose, R. 2012. Reference section of the Lower Permian San Andres Formation, Sierra County, New Mexico. New Mexico Geological Society Guidebook, 63rd Field Conference, Warm Springs Region, 395-406.

Krainer, K., Lucas, S., and Vachard, D. 2009. Facies, microfossils (smaller foraminifers, calcareous algae) and biostratigraphy of the Hueo Group, Doña Ana Mountains, southern New Mexico, USA. Rivista Italiana di Stratigrafia e Paleontologia, 115: 3-26.

Krainer, K. and Vachard D. 2011. The Lower Triassic Werfen Formation of the Karawanken Mountains (southern Austria) and its disaster survivor microfossils, with emphasis on Postcladella n. gen. (Foraminifera, Miliolata, Cornuspirida). Revue de Micropaléontologie, 54:59-85.

Krainer, K., Vachard, D., and Lucas, S.G. 2003. Microfacies and microfossil assemblages (smaller foraminifers, algae, pseudoalgae) of the Hueco Group and Laborcita Formation (Upper Pennsylvanian-Lower Permian), south-ccntral New Mexico, USA. Rivista Italiana de Stratigrafia e Paleontologia, 109:3-36.

Kulagina, E.I., Rumyantseva, Z.C., Pazukhin, V.N., and Kochetova, N.N., 1992. Granitsa nizhnego-srednego karbona na yuzhnom Urale i srednem Tyan-Shane (Lower-Middle Carboniferous boundary in the southern Urals and central Tian-Shan). Rossiiskaya Akademiya Nauk, Uralskoe Otdelenie, Bashkirskii Nauchnyi Tsentr, Institut Geologii, Moskva, Nauka. (In Russian)

Kützing, F.T. 1843. Phycologia Generalis oder Anatomie, Physiologie und Systemkunde der Tange. F. A. Brockhaus, Leipzig.
Lambert, L.L., Wardlaw, B.R., Nestell, M.K., and Nestell, G.P. 2002. Latest Guadalupian (Middle Permian) conodonts and foraminifers from West Texas. Micropaleontology, 48:343-364.

Lamouroux, J.V.F. 1812. Extrait d'un mémoire sur la classification des Polypiers coralligènes non entièrement pierreux. Nouveau Bulletin des sciences/ par la Société Philomathique de Paris, 3:181-188.

Lankester, E.R. 1885. Protozoa, p. 830-866. In Traioll, T.S. (ed.), Encyclopedia Britannica 17 (ninth edition).

Leven, E.Ya. 1992. Problems of Tethyan Permian stratigraphy. International Geology Review, 34:976-985.

Leven, E.Ya. 1993. Main events in Permian history of the Tethys and fusulinids. Stratigraphy and Geological Correlation (English translation from Stratigrafiya, Geologicheskaya Korrelyatsiya), 1:59-75.

Leven, E.Ya. 2003. The Permian stratigraphy and fusulinids of the Tethys. Rivista Italiana di Paleontologia e Stratigrafia, 109:267-280.

Li, C. and Mamet, B., 1993. Late Carboniferous and Early Permian algal microflora (Liuzhou, South China). Bulletin of Canadian Petroleum Geology, 41:70-78.

Lin, J.X. 1978. Carboniferous and Permian Foraminiferida, p. 10-43. In Hubei Institute of Geological Science and others (eds.), Paleontological atlas of Central South China (micropaleontological volume). Geological Publishing House, Beijing. (In Chinese)

Lin, J.-X. 1984. Protozoa, p. 110-177 (In Chinese), 323364 (In English). In Yichan Institute of Geology and Mineral Resources (ed), Biostratigraphy of the Yangtze Gorge area chiefly, 3)) late Paleozoic era. Museum Changzhou, Changzhou City, Jiangsu Province, Geological Publishing House, Beijing.

Lin, J.X., Li, L.X., and Sun, Q.Y. 1990. Late Paleozoic foraminifers in South China. Science Publication House. (In Chinese).

Lipina, O.A. 1949. Melkie foraminifery pogrebennykh massivov Bashkirii (Smaller foraminifers from the buried massifs of Bashkiria). Akademiya Nauk SSSR, Trudy Instituta Geologicheskikh Nauk, 105, ser. geol., 35:198-235. (In Russian; French translation BRGM, $\mathrm{n}^{\circ}$ 791).

Loeblich, A.R. and Tappan, H. 1961. Suprageneric classification of the Rhizopodea. Journal of Paleontology, 35:245-330.

Loeblich, A.R. and Tappan, H. 1964. Sarcodina, chiefly "Thecamoebians" and Foraminiferida, p. C1-C900. In Moore R.C. (ed.), Treatise of Invertebrate Paleontology, Part C, Protista 2. The Geological Society of America and the University of Kansas.

Loeblich, A.R. and Tappan, H. 1987. Foraminiferal genera and their classification. Van Nostrand Reinhold Company Publisher, (Volume 1).

Lucas, S.G. and Krainer, K. 2012. The Lower Permian Yeso Group in the Fra Cristobal and Caballo Mountains, Sierra County, New Mexico. New Mexico Geological Society Guidebook, 63 ${ }^{\text {rd }}$ Field Conference, Warm Springs Region: 63:377-394. 
Lucas, S.G., Krainer, K., and Vachard, D. 2015. The Lower Permian Hueco Group, Robledo Mountains, New Mexico (U.S.A.). New Mexico Museum of Natural History and Science Bulletin, 65:43-95.

Lucas, S.G., Krainer, K., Chaney, D.S., DiMichele, W.A., Voigt, S., Berman, D., and Henrici, A.C. 2013a. The Lower Permian Abo Formation in central New Mexico. New Mexico Museum of Natural History and Science, Bulletin, 59:161-180.

Lucas, S.G., Krainer, K., and Voigt, S. 2013b. The Lower Permian Yeso Group in central New Mexico. New Mexico Museum of Natural History and Science, Bulletin, 59:181-200.

Lucas, S.G., Krainer, K., and Brose, R.J. 2013c. The Lower Permian Glorieta Sandstone in central New Mexico. New Mexico Museum of Natural History and Science, Bulletin, 59:201-212.

Lucas, S.G., Krainer, K., and Colpitts, R.M. Jr. 2005. Abo-Yeso (Lower Permian) stratigraphy in central New Mexico. New Mexico Museum of Natural History and Science Bulletin, 31:101-117.

Macfadyen, W.A. 1939. On Ophthalmidium, and two names for Recent foraminifera of the family Ophthalmidiidae. Journal of the Royal Microscopical Society, 59: 162-169.

Magginetti, R.T., Stevens, C.H., and Stone, P. 1988. Early Permian fusulinids from the Owens Valley Group, east-central California. Geological Society of America, Special Paper, 217:1-61.

Mamet, B.L. 1996. Late Paleozoic small foraminifers (endothyrids) from South America (Ecuador and Bolivia). Canadian Journal of Earth Sciences, 33:452459.

Mamet, B. and Pinard, S. 1992. Note sur la taxonomie des petits foraminifères du Paléozoïque supérieur. Bulletin de la Société belge de Géologie, 99 (1990):373-398.

Mamet, B. and Pinard, S. 1996. Nodosinelloides potievskayae, nomen novum (foraminifère). Revue de Micropaléontologie, 39:223.

Mamet, B. and Pohler, S.M.L. 2002. Algae from the Early and Middle Devonian limestones Tamworth Belt, New South Wales, Australia. Alcheringa, 26:435-450.

Mamet, B. and Préat, A. 1985. Sur quelques algues vertes nouvelles du Givétien de la Belgique. Revue de Micropaléontologie, 28:67-74.

Mamet, B. and Préat, A. 1992. Algues du Dévonien moyen de Wellin (synclinorium de Dinant, Belgique). Revue de Micropaléontologie, 35:53-75.

Mamet, B. and Préat, A. 1994. Algues calcaires de l'Eifélien inférieur (calcaire de Couvin, synclinorium de Dinant). Revue de Micropaléontologie, 37:135159.

Mamet, B., Préat, A., and Roux, A. 1993. Présence de Gymnocodium (algue) dans le Dévonien moyen (synclinorium de Dinant, Belgique). Revue de Micropaléontologie, 27:175-180.
Mamet, B. and Roux, A. 1984. Poncetellina nomen novum (algue verte). Revue de Micropaléontologie, 27:138.

Mamet, B.L., Roux, A., and Nassichuk, W.W. 1987. Algues carbonifères et permiennes de l'Arctique canadien. Geological Survey of Canada, Bulletin, 342:1143.

Mamet, B. and Zhu Z. 2005. Carboniferous and Permian algal microflora; Tarim Basin (China). Geologica Belgica, 8:3-13.

Maslov, V.P. 1956. Iskopaemye izvestkovye vodorosli SSSR. Akademiya Nauk SSSR, Trudy Instituta Geologicheskikh Nauk, 160:1-301. (In Russian; French translation BRGM no 3517)

Maslov, V.P. 1973. Atlas porodoobrazuyub shchikh organizmov (izvestkovykh i kremnevykh). Izdatelstvo "Nauka". (In Russian)

Mello, J. 1977. Plexoramea cerebriformis n. gen. n. sp. and some other microproblematics and microfossils from Triassic limestones of the West Carpathians. Západné Karpaty, séria paleontólogia, 2-3:189-202.

Mikhailov, A. 1935. K voprosu filogenii kamennougolnykh foraminifer. Izvestiya Leningradskogo GeologoGidro-Geodezicheskogo Tresta, 2-3:38-42. (In Russian)

Mikhailov, A. 1939. K kharakteristike rodov nizhnekamennougolnykh foraminifer territorii SSSR; nizhnekamennougolnye otlozhenii severo-zapadnogo kryla Podmoskogo basseina. Sbornik Leningrad Geologicheskogo Upraleniya, Symposium, 3:47-62. (In Russian)

Mikhalevich, V.I. 1988. Sistema podklassa Miliolata (Foraminifera). Trudy Zoologicheskogo Instituta, Akademiya Nauk SSSR, 184:77-110. (In Russian)

Mikhalevich, V.I. 1993. New higher taxa of the subclass Nodosariata (Foraminifera). Zoosystematica Rossica, 2:5-8.

Mikhalevich, V.I. 1998. Makrosistema Foraminifer. Izvestiya Akademiya Nauk SSSR, seriya biologicheskaya 2, 266-271. (In Russian)

Miklukho-Maklay, A.D. 1953. K sistematike semeytsva Archaediscidae. Ezhegodnik Vsesoyuznogo Paleontologischeskogo Obshchestva (1948-1953), 14:127131. (In Russian)

Miklukho-Maklay, A.D. 1958. Novoe semeystvo foraminifer - Tuberitinidae M.-Maclay fam. nov. Voprosy Mikropaleontologii, 2:130-135. (In Russian)

Miklukho-Maklay, K.V. 1968. New Late Permian miliolids and rotaliids. Novye vidy drevnikh rasteniy $i$ bespozvonochnykh SSSR, part 2:137-146. (In Russian)

Morozova, V.G. 1949. Predstaviteli semeytsv Lituolidae $i$ Textulariidae iz verkhnekamennougolnykh $i$ artinski otlozhenii bashkirskogo Priuralya. Akademyia Nauk SSSR, Trudy Instituta Geologicheskikh Nauk, 105, geologicheskaya seriya, 35:244-275 (In Russian; French translation: BRGM, $\mathrm{n}^{\circ} 783$ ) 
Moshier, O. and Kirkland, B. 1993. Identification and diagenesis of a phylloid alga: Archaeolithophyllum from the Pennsylvanian Providence Limestone, Western Kentucky. Journal of Sedimentary Petrology, 63:1032-1041.

Mu, Xinan 1982. Some calcareous algae from Xizang. In The series of the Scientific Expedition to the QinghaiXizang Plateau. Paleontology of Xizang, Book V:205238, Science Press, Beijing. (In Chinese)

Mu, Xinan and Riding, R. 1983. Silicified gymnocodiacean algae from the Permian of Nanjing, China. Palaeontology, 26:261-276.

Nestell, G.P. and Nestell, M.K. 2006. Middle Permian (Late Guadalupian) foraminifers from Dark Canyon, Guadalupe Mountains, New Mexico. Micropaleontology, 52:1-50.

Nestell, M.K., Nestell, G.P., Wardlaw, B.R., and Sweatt, M.J. 2006. Integrated biostratigraphy of foraminifers, radiolarians and conodonts in shallow and deep water Middle Permian (Capitanian) deposits of the "Rader slide", Guadalupe Mountains, West Texas. Stratigraphy, 3:161-194.

Nestell, G.P., Sudar, M.N., Jovanovic, D., and KolarJurkovsek, T. 2009. Latest Permian foraminifers from the Vlasic Mountain area, northwestern Serbia. Micropaleontology, 55:495-513.

Nguyen, D.T. 1979. Etude micropaléontologique (foraminifères) de matériaux du Permien du Cambodge. Unpublished PhD Thesis, Université Paris Sud, Orsay.

Noé, S. 2003. Spätstadium einer sterbenden Karbonatplattform: Shelfrand- und Aubenshelf-Entwicklung der Tansill-Formation (Permian Reef Complex, New Mexico, USA). Kölner Forum für Geologie und Paläontologie, 11:1-254.

Obrhel, J. 1968. Maslovina meyenii n. gen. et n. sp., neue Codiacea aus dem Silur Böhmens. Vestnik ústred Ustavu geol, 43:367-370.

Ogilvie-Gordon, M.M. 1927. Das Grödener-, Fassa- und Enneberggebiet in den Südtiroler Dolomiten; Teil IIIPaläontologie. Abhandlungen der Geologischen Bundesanstalt, 24:1-89.

Okimura, Y. and Ishii, K.-i. 1981. Smaller foraminifera from the Abadeh Formation, Abadehian stratotype, central Iran. Reports Geological Survey Iran, 49:727.

Okimura, Y., Ishii, K-i, and Ross, C.A. 1985. Biostratigraphical significance and faunal provinces of Tethyan Late Permian smaller foraminifera, p. 115138. In Nakazawa, K. and Dickins, J.M. (eds.), The Tethys, Her Paleogeography and Paleobiogeography from Paleozoic to Mesozoic. Tokai University Press, Tokai.

Panzanelli-Fratoni, R., Limongi, P., Ciarapica, G., Cirilli, S., Martini, R., Salvini-Bonnard, G., and Zaninetti, L. 1987. Les Foraminifères du Permien supérieur remaniés dans le "Complexe Terrigène" de la formation triasique du Monte Facito, Apennin méridional. Revue de Paléobiologie, 6:293-319.
Papenfuss, G.F. 1955. Classification of the algae, p. 115224. In Kessel, E.L. (ed.), A Century of Progress in the Natural Sciences 1853-1953. California Academy of Science, San Francisco.

Parvizi, T., Rashidi, K., and Vachard, D. 2013. Middle Permian calcareous algae and microproblematica (Dalan Formation, Dena Mountain, High Zagros, SW Iran). Facies, 59:149-177, doi:10.1007/s10347-0120357-6

Pérez-Ramos, O. 1992. Permian biostratigraphy and correlation between southeast Arizona and Sonora. Boletín del Departamento de Geología de la Universidad de Sonora, 9 (2):1-74.

Pérez-Ramos, O. and Nestell, M. 2002. Permian fusulinids from Cobachi, central Sonora, Mexico. Revista Mexicana de Ciencias Geológicas, 19:25-37.

Pille, L. 2008. Foraminifères et algues calcaires du Mississippien supérieur (Viséen supérieur-Serpukhovien): rôles biostratigraphique, paléoécologique et paléogéographique aux échelles locale, régionale et mondiale. Unpublished PhD Thesis, Université Lille1, Villeneuve d'Ascq.

Pille, L., Vachard, D., and Aretz, M., 2007. Evolutionary trends in the superfamilies Archaediscoidea and Lasiodiscoidea - maximal complexity of a small, undivided tube of Carboniferous-Permian foraminifers. Journal of Stratigraphy, 31 (supplement 1):73.

Pinard, S. and Mamet, B., 1998. Taxonomie des petits foraminifères du Carbonifère supérieur-Permien inférieur du bassin de Sverdrup, Arctique canadien. Palaeontographica Canadiana, 15:1-253.

Pintigore, N.E. 1994. Identification and diagenesis of a phylloid alga; Archaeolithophyllum from the Pennsylvanian Providence Limestone, western Kentucky; discussion. Journal of Sedimentary Research, 64:923-924.

Plummer, H.J. 1945. Smaller foraminifera in the Marble Falls, Smithwick, and lower Strawn strata around the Llano uplift in Texas. Bulletin University of Texas, 4401:209-265.

Pokorny, V. 1958. Grundzüge der zoologischen Mikropaläontologie. VEB Deutscher Verlag der Wissenschaften, Berlin.

Poncet, J. 1982. L'apport des Udoteaceae (Algues vertes calcaires) dans la paléogéographie mondiale éodévonienne. Bulletin de la Société Géologique de France, 7:1087-1091.

Poncet, J. 1990. Biogeography of Devonian algae, p. 285-289. In McKerrow, W.S. and Scotese C.R. (eds.), Palaeozoic Palaeogeography and Biogeography. Geological Society London, Memoirs, London.

Potievskaya, P.D. 1962. Predstaviteli nekotorykh semeystv melkikh foraminifer iz nizhney permi severozapadnoy okrainy Donbassa. Akademiya Nauk Ukrainskoi SSR, Instituta Geologicheskikh Nauk, Trudy, seriya stratigrafii i paleontologii, 44:49-94. (In Russian) 
Pray, L.C. and Wray, J.L. 1963. Porous algal facies (Pennsylvanian), Honaker Trail, San Juan Canyon, Utah, p. 204-234. In Bass, R.O. (ed.), Shelf Carbonates of the Paradox Basin. Four Corners Geological Society Symposium, Fourth Field Conference Guidebook, Durango.

Pronina, G.P. 1988. Poznepermskie Miliolyaty Zakavkazya. Trudy Zoologicheskogo Instituta AN SSSR, 184:49-63. (In Russian)

Pronina, G.P. 1994. Sistema $i$ filogeniya otryada Hemigordiopsida (foraminifery). Paleontologicheskii Zhurnal, 1994 (3):13-24. (In Russian; English translation: Paleontological Journal, 28(3):13-27)

Pronina, G.P. 1999. Korrelyatsiya verkhnepermiskikh otlozhenii Borealnoi oblasti po melkim foraminiferam. Doklady meshdunarodnogo simpoziuma "Verkhnepermskie stratotipy Povolzhya" (Proceedings of the International Symposium: "Upper Permian stratotypes of the Volga Region"). GEOS, Moskva:182188. (In Russian)

Pronina-Nestell, G.P. and Nestell, M.K. 2001. Late Changhsingian foraminifers of the northwestern Caucasus. Micropaleontology, 47:205-234.

Radoicic, R. 2004. Permocalculus nikolapantici n. sp. (Udoteaceae?) from the Upper Turonian of the NW Serbia. Bulletin de l'Académie serbe des sciences et des arts, Classe des sciences mathématiques et naturelles, Sciences naturelles, 128:237-257.

Rauzer-Chernousova, D.M. 1949. Stratigrafiya verkhnekamennougolnykh i artinskikh otlozheniy bashirkogo Priuralya. Akademiya Nauk SSSR, Geologichevskii Intitut Trudy, 105, geologichevskaya seriya 35: 3-21. (In Russian, French translation by Pietresson de St-Aubin, Institut Français du Pétrole, des Carburants et Lubrifiants, no. 1522-747:1-18)

Rauzer-Chernousova, D.M. 1950. Fatsii verkhnekamennougolnykh $i$ artinskikh otlozhenii SterlitamakskoIshimbayskogo Priural'ya (na osnove izucheniya fuzulinid). Akademiya Nauk SSSR, Trudy Instituta Geologicheskikh Nauk, 119, geologicheskaya seriya, 43:1-109. (In Russian)

Razgallah, S. and Vachard, D. 1991. Systématique et biosédimentologie des algues constructrices permiennes Tubiphytes et Archaeolithoporella suivant l'exemple du Djebel Tebaga (Murghabien de Tunisie). Palaeontographica, B, 221:171-205.

Reichel, M. 1945. Sur un Miliolidé nouveau du Permien de l'île de Chypre. Verhandlungen der Naturforschenden Gesellschaft in Basel, 56:521-530.

Reichel, M. 1946. Sur quelques foraminifères nouveaux du Permien méditerranéen. Eclogae Geologicae Helvetiae, 38:524-560.

Reiss, Z. 1963. Reclassification of perforate Foraminifera. Bulletin of the Geological Survey of Israel, 35:1111.

Reitlinger, E.A. 1949. Melkie foraminifery nizhnei chasti srednego Karbona Srednego Urala i Prikamya. Akademiya Nauk SSSR, Izvestia, seriya geol., 6:149164. (In Russian)
Reitlinger, E.A. 1950. Foraminifery srednekamennougolnykh otlozhenii tsentralnoi chasti Russkoi platformy (isklyuchaya semeistvo Fusulinidae). Trudy Instituta Geologicheskikh Nauk, 126, geologichevskaya seriya, 47:1-126. (In Russian, French translation $\left.B R G M n^{\circ} 1456\right)$

Reitlinger, E.A. 1965. Razvitie foraminifer $v$ pozdnepermskogo $i$ rannetriasovyuf epokhi na territorii Zakavkazya. Voprosy Mikropaleontologii, 9:45-70. (In Russian)

Rettori, R. 1994. Replacement name Hoyenella, gen. n. (Triassic Foraminiferida, Miliolina) for Glomospira sinensis Ho, 1959. Bolletino della Società Paleontologica Italiana, 33:341-343.

Rhumbler, L. 1895. Entwurf eines natürlichen Systems der Thalamophoren. Nachrichten von der Gesellschaft der Wissenschaften zu Göttingen, Math.-Phys. Klasse, Jahr. 1895:51-98.

Rich, M. 1980. Carboniferous calcareous Foraminifera from northeastern Alabama, south-central Tennessee, and northwestern Georgia. Cushman Foundation for Foraminiferal Research, Special Publication, 18:1-62.

Riding, R. 1993. Shamovella obscura: the correct name for Tubiphytes obscurus: (Fossil). Taxon, 42:71-73.

Riding, R. and Barkham, S. 1999. Temperate water Shamovella from the Lower Permian of West Timor, Indonesia. Alcheringa, 23:21-29.

Riding, R. and Guo, Li 1992. Affinity of Tubiphytes. Palaeontology, 35(1):37-49.

Rietschel, S. 1966. Scribroporella, eine Dasycladacee aus dem Mitteldevon des Bergischen Landes (Rheinisches Schiefergebirge). Senckenbergiana lethaea, 47:193-213.

Rigby, K. 1958. Two new Upper Paleozoic hydrozoans. Journal of Paleontology, 32: 583-586.

Ross, C.A. 1960. Fusulinids from the Hess Member of the Leonardian Formation, Leonard Series (Permian) Glass Mountains, Texas. Contributions from the Cushman Foundation for Foraminiferal Research, 11(4):117-133.

Ross, C.A. 1962. Fusulinids from the Leonard Formation (Permian), western Glass Mountains, Texas. Contributions from the Cushman Foundation for Foraminiferal Research, 13:1-21.

Ross, C.A. 1986. Paleozoic evolution of southern margin of Permian basin. Geological Society of America Bulletin, 97:536-554.

Ross, C.A. 1995. Permian fusulinaceans, p. 167-185. In Scholle, P.A., Peryt, T.M., and Ulmer-Scholle, D.S. (eds.), The Permian of Northern Pangea. SpringerVerlag, Berlin, Heidelberg.

Ross, C.A. and Ross, J.R.P. 1987. Late Paleozoic sea levels and depositional sequences. Cushman Foundation for Foraminiferal Research, Special Publication, 38:137-149. 
Ross, C.A. and Ross, J.R.P. 1995. Permian sequence stratigraphy, p. 98-123. In Scholle, P.A., Peryt, T.M., and Ulmer-Scholle, D.S. (eds.), The Permian of Northern Pangea. Springer-Verlag, Berlin, Heidelberg.

Ross, C.A. and Ross, J.R.P. 1997. Hessian (Leonardian, Middle Lower Permian) depositional sequences and their fusulinid zones, West Texas. Cushman Foundation for Foraminiferal Research, Special Publication, 38:119-124.

Ross, C.A. and Ross, J.R.P. 2003. Sequence evolution and sequence extinction: fusulinid biostratigraphy and species-level recognition of depositional sequences, Lower Permian, Glass Mountains, West Texas, U.S.A. SEPM (Society for Sedimentary Geology,) Special Publication, 75:317-359.

Rothpletz, A. 1894. Ein geologischer Querschnitt durch die Öst-Alpen nebst Anhang über die sog. Glarner Doppelfalte. Schweizerbart Verlag, Frankfurt.

Rothpletz, A. 1908. Über Algen und Hydrozoen im Silur von Gotland und Oesel. Kungliga Svenska Vetenskapsakademiens Handlingar, 43:1-25.

Roux, A. 1985. Introduction à l'étude des algues fossiles paléozoïques (de la bactérie à la tectonique des plaques). Bulletin Centres Recherche ExplorationProduction Elf-Aquitaine, 9:465-699.

Roux, A. 1991. Révision des Gymnocodiaceae (Algues rouges, Permien-Crétacé) : taxonomie, biostratigraphie, paléobiogéographie, 2e partie : Inventaire taxonomique critique des espèces de Gymnocodiacées du Permien et du Trias. Revue de Micropaléontologie, 34:136-173.

Ruget, C. 1976. Révision des foraminifères de la collection Terquem. I-Lias : Dentalina, Marginulina, Nodosaria. Cahiers de Micropaléontologie, 1976(4):1-119.

Rzehak, A. 1885. Bemerkungen über einige Foraminiferen der Oligocän Formation. Verhandlungen des Naturforschenden Vereins in Brünn, 23:123-129.

Saidova, Kh.M. 1975. Bentosnye foraminifery Tikhogo okeana. Akademiya Nauk SSSR, Institut Okeanologii im Moscow: P.P. Shirshova, Moscow. (In Russian)

Saidova, Kh.M. 1981. O sovremennom sostoyanii sistemy nadvidovykh taksonov kaynozoyskikh bentosnykh foraminifer. Akademiya Nauk SSSR, Institut Okeanologii im Moscow: P.P. Shirshova, Moscow. (In Russian)

Saltovskaya, V.D. 1981. Siluriiskie i devonskie foraminifery Zeravchano-Gissarskoi gornoi oblasti. Voprosy Mikropaleontologii, 24:105-115. (In Russian)

Salvador, A. 1994. International stratigraphic guide. A guide to stratigraphic classification, terminology, and procedure. International Subcomission on Stratigraphic classification of IUGS, International Subcommission of Stratigraphy (Second Edition). International Union of Geological Sciences and the Geological Society of America, Boulder, Colorado.
Sano, H., Horibo, K., and Kumamoto, Y. 1990. Tubiphytes-Archaeolithoporella-Girvanella reefal facies in Permian buildup, Mino terrane, central Japan. Sedimentary Geology, 68:293-306.

Schaffner, J.H. 1922. The classification of plants XII. Ohio Journal of Science, 22:129-139.

Schellwien, E. 1898. Die Fauna des Karnischen Fusulinenkalks. Theil 2: Foraminifera. Palaeontographica (1897), 44:237-282.

Scherp, H. 1962. Foraminiferen aus dem unteren und mittleren Zechstein Nordwestdeutschlands, inbesondere der Bohrung Friedrich Heinrich 57 bei Kamp-Lintfort, p. 265-330. In Der tiefere Untergrund der Niederrheinischen Bucht. Fortschritte in der Geologie von Rheinland und Westfalen, Krefeld.

Schlagintweit, F. 2010. Gosavisiphon gen. nov. based on Halimeda paucimedullaris Schlagintweit and Ebli, 1998, a remarkable macroalga (Udoteaceae?) from the Late Cretaceous of the Northern Calcareous Alps (Austria and Germany) with affinites to Late Paleozoic and Late Triassic phylloids. Geologica Croatica, 63:27-53.

Schlagintweit, F., Krainer, K., and Lucas, S.G. 2013. The oldest record of a boring foraminifer: Early Permian of New Mexico, USA. Lethaia, 46:245-250.

Schlagintweit, F. and Sanders, D. 2007. Permocalculus (Pyrulites) theresiensteinensis $\mathrm{n}$. sp., a new calcareous alga from the Upper Cretaceous Lower Gosau Subgroup of the Northern Calcareous Alps (Austria). Jahrbuch der Geologischen Bundesanstalt, 147:607614.

Scholle, P.A. and Ulmer-Scholle, D.S. 2003. A color guide to the petrography of carbonate rocks: grains, textures, porosity, diagenesis. American Association of Petroleum Geologists Memoir, 77:1-461.

Schubert, R.J. 1908. Beiträge zu einer natürlichen Systematik der Foraminiferen. Neues Jahrbuch für Mineralogie, Geologie und Paläontologie Beilage-Band, 25:232-260.

Schubert, R.J. 1921. Paläontologische Daten zur Stammesgeschichte der Protozoen. Paläontologische Zeitschrift, 3 (1920) (2):129-188.

Schultze, M.S. 1854. Über den Organismus der Polythalamien (Foraminiferen) nebst Bemerkungen über die Rhizopoden im allgemeinen. Wielhem Engelmann, Leipzig.

Sellier de Civrieux, J.M. and Dessauvagie, T.F.J. 1965. Reclassification de quelques Nodosariidae, particulièrement du Permien au Lias. Maden Tetkik ve Arama (M.T.A.) Enstitüsü Yayinlarindan, 124:1-178.

Senowbari-Daryan, B. 1984. Mikroproblematika aus den obertriadischen Riffkalken von Sizilien. Münstersche Forschungen zur Geologie und Paläontologie, 61:181.

Senowbari-Daryan, B., Bucur, I.I., Schlagintweit, F., Sasaran, E., and Matyszkiewicz, J. 2008. Crescentiella, a new name for "Tubiphytes" morronensis Crescenti, 1969: an enigmatic Jurassic-Cretaceous microfossil. Geologica Croatica, 61:185-214. 
Senowbari-Daryan, B. and Flügel, E. 1993. Tubiphytes Maslov, an enigmatic fossil: classification, fossil record and significance through time, part I: discussion of late Paleozoic material, p. 353-382. In Barattolo F., De Castro P., and Parente M. (eds.), Studies on fossil benthic algae. Bolletino della Società Italiana, special volume, Modena.

Senowbari-Daryan, B. and Rashidi, K. 2010. The codiacean genera Anchicodium Johnson, 1946, Iranicodium nov. gen. from the Permian Jamal Formation of Shotori Mountains, Northeast Iran. Rivista Italiana di Paleontologia e Stratigrafia, 116:3-21.

Shuysky, V.P. 1985. O polozhenii paleoberezellid i drugikh segmetirovannykh vodoroslei v sisteme Siphonophyceae. In Chuvashov, B.I. (ed), Novye dannye po geologii, biostratigrafii i paleontologii Urala. Akademiya Nauk SSSR, Uralskii Nauchnyi Tsentr, Institut Geologii i Geokhimii:86-95. (In Russian)

Skinner, J.W. and Wilde, G.L. 1954. The fusulinid subfamily Boultoniinae. Journal of Paleontology, 28:434444.

Song, H., Tong, J., Chen, Z.Q., Yang, H., and Wang, Y. 2009. End-Permian mass extinction of foraminifers in the Nanpanjiang basin, South China. Journal of Paleontology, 83:718-738.

Song, H., Tong, J., and Chen, Z.Q. 2011. Evolutionary dynamics of the Permian-Triassic foraminifer size: Evidence for Lilliput effect in the end-Permian mass extinction and its aftermath. Palaeogeography, Palaeoclimatology, Palaeoecology, 308:98-110.

Sosipatrova, G.P. 1972. Upper Palaeozoic foraminifera of Spitsbergen. In Sokolov, V.N, Stratigraphy of Spitsbergen, Institut Geologi Arktiki Leningrad:1- 238. (In Russian; translated by Francis, E.T. and Klener, G. Lending Division of the British Library Board:125163).

Sosnina, M.I., 1983. Nekotorye novye predstaviteli miliolid i nodozariid pozdney permi Yuzhnogo Primorya (Foraminifery). Ezhegodnik Vsesoyuznogo Paleontologischeskogo Obshchestva, 26:29-47. (In Russian)

Sosnina, M.I. 1977. Nodozariidy pozdnei Permi Yuzhnogo Primorya. Ezhegodnik Vsesoyuznogo Paleontologicheskogo Obshchestva, 20:10-31. (In Russian)

Spandel, E. 1901. Die Foraminiferen des Permo-Karbon von Hooser, Kansas, Nord Amerika. Festschrift der naturhistorische Gesellschaft in Nürnberg:175-194.

Stevens, C.H. and Stone, P. 2007. The PennsylvanianEarly Permian Bird Spring carbonate shelf, southeastern California: fusulinid biostratigraphy, paleogeographic evolution, and tectonic implications. Geological Society of America, Special Paper, 429:182.

St Jean, J. 1957. A Middle Pennsylvanian foraminiferal fauna from Dubois Country, Indiana. Indiana Department of Conservation, Geological Survey, Bulletin, 10: 1-66.
Tappan, H. and Loeblich, A.R. 1988. Foraminiferal evolution, diversification and extinction. Journal of Paleontology, 62:695-714.

Thompson, M.L. 1948. Studies of American fusulinids. University of Kansas, Paleontological Contributions, Protozoa, Article 1:1-184.

Thompson, M.L. 1964. Fusulinacea, p. C358-C436. In Loeblich A.R. and Tappan H. (eds.), Treatise on Invertebrate Paleontology, Part C: Protista 2; Sarcodina chiefly Thecamoebians and Foraminiferida. Geological Society America and University Kansas Press, Boulder, Colarado and Lawrence, Kansas: C1-C900.

Tong, S. and Shi, G.R. 2000. Evolution of the Permian and Triassic Foraminifera in South China, p. 291307. In Yin, H., Dickins, J.M., Shi, G.R., and Tong, J. (eds.), Permian-Triassic Evolution of Tethys and Western Circum-Pacific. Elsevier, Amsterdam.

Toomey, D.F. 1972. The biota of the Pennsylvanian (Virgilian) Leavenworth Limestone, Midcontinent. part 3: distribution of calcareous Foraminifera. Journal of Paleontology, 46:276-298.

Torres, A.M. 2003. Sexual reproductive structures in the green alga Ivanovia triassica. Lethaia, 36:33-40.

Torres, A.M., West, R.R., and Sawin, R.S. 1992. Calcipatera cottonwoodensis, a new membranous Late Paleozoic alga. Journal of Paleontology, 66:678-681.

Toula, F. 1884. Geologische Untersuchungen im westlichen Theile des Balkan und in den angrenzenden Gebieten. X. Von Pirot nach Sofia, auf dem Vitos, über Pernik nach Trn und über Stol nach Pirot. Sitzungsberichte der Kaiserlichen Akademie der Wissenschaften in Wien, 88:1279-1348.

Ueno, K. and Sakagami, S. 1993. Middle Permian foraminifers from Ban Nam Suai Tha Sa-at Changwat Loei, Northeast Thailand. Transactions and Proceedings of the Palaeontological Society of Japan, n.s., 172:277-291.

Vachard, D. 1980. Téthys et Gondwana au Paléozoïque supérieur; les données afghanes : biostratigraphie, micropaléontologie, paléogéographie. Documents et Travaux IGAL, Institut Géologique Albert de Lapparent, 2, Paris.

Vachard, D. 1988. Calcareous microfossils (algae, pseudo-algae and foraminifera) from La Serre, Montagne Noire, France. Courier Forschungsinstitut Senckenberg, 100:139-147.

Vachard, D. 1993. Algues, pseudo-algues et microfaciès carbonatés du Dévonien du Domaine Ligérien (Massif Armoricain, France). Palaeontographica, $B$, 229:53-113.

Vachard, D. 1994. Foraminifères et moravamminides du Givétien et du Frasnien du domaine Ligérien (Massif Armoricain, France). Palaeontographica, A, 231:192.

Vachard, D. and Beckary, S. 1991. Algues et foraminifères bachkiriens des coal balls de la Mine Rosario (Truebano, Léon, Espagne). Revue de Paléobiologie, 10:315-357. 
Vachard, D. and Cózar, P. 2010. An attempt of classification of the Palaeozoic incertae sedis Algospongia. Revista Española de Micropaleontología, 42:129241.

Vachard, D. and Ferrière, J. 1991. Une association à Yabeina (foraminifère fusulinoïde) dans le Midien (Permien supérieur) de la région de Whangaroa (Baie d'Orua, Nouvelle-Zélande). Revue de Micropaléontologie, 34:201-230.

Vachard, D., Flores de Dios, A., Buitrón, B.E., and Grajales-Nishimura, M. 2000a. Biostratigraphie par fusulines des calcaires carbonifères et permiens de San Salvador Patlanoaya (Puebla, Mexique). Geobios, 33:5-33.

Vachard, D., Flores de Dios, A., Pantoja, J., Buitrón, B., Arellano, J., and Grajales, M. 2000b. Les fusulines du Mexique, une revue biostratigraphique et paléogéographique. Geobios, 33:655-679.

Vachard, D., Fourcade, E., Romero, J.E., Mendez, J., Cosillo, A., Alonzo, M., Requena, J., Azema, J., and Cros, P. 1997. Foraminifères et algues du Permien du Guatemala. Geobios, 30:745-784.

Vachard, D., Gaillot, J., Pille, L., and Blazejowski, B. 2006. Problems on Biseriamminoidea, MississippianPermian biserially coiled foraminifera; a reappraisal with proposals. Revista Española de Micropaleontología, 38: 453-492.

Vachard, D., Gaillot, J., Vaslet, D., and Le Nindre, Y.M. 2005. Foraminifera and algae from the Khuff Formation (late Middle Permian-Early Triassic) of central Saudi Arabia. GeoArabia, 10:137-186.

Vachard D., Gargouri-Razgallah S., and Chaouachi M.C. 1989a. Sur les biohermes à algues solénoporacées et phylloïdes du Permien supérieur de Tunisie (Murghabien du Djebel Tebaga) et sur les incidences de la diagenèse carbonatée sur la systématique algaire. Revue de Paléobiologie, 8:121-141.

Vachard, D., Haig, D.W., and Mory, A.J. 2014. Middle Visean foraminifers and algae from a shallow interior sea in Western Australia. Geobios, 47:57-74.

Vachard, D., Hauser, M., Martini, R., Zaninetti, L., Matter, A., and Peters, T. 2001. New algae and problematica of algal affinity from the Permian of the Aseelah Unit of the Batain Plain, (East Oman). Geobios, 34:375404.

Vachard, D. and Krainer, K. 2001a. Smaller foraminifers of the Upper Carboniferous Auernig Group, Carnic Alps (Austria/ltaly). Rivista Italiana di Paleontologia e Stratigrafia, 107:147-168.

Vachard, D. and Krainer, K. 2001b. Smaller foraminifers, characteristic algae and pseudo-algae of the latest Carboniferous/Early Permian Rattendorf Group, Carnic Alps (Austria/ltaly). Rivista Italiana de Paleontologia e Stratigrafia, 107:169-195.
Vachard, D., Krainer, K., and Lucas, S.G. 2012. Pennsylvanian (Late Carboniferous) calcareous microfossils from Cedro Peak (New Mexico, USA); Part 1: algae and microproblematica. Annales de Paléontologie, 98:225-252.

Vachard, D., Krainer, K., and Lucas, S.G. 2013a. Pennsylvanian (Late Carboniferous) calcareous microfossils from Cedro Peak (New Mexico, USA); Part 2: smaller foraminifers and fusulinids. Annales de Paléontologie, 99:1-42.

Vachard, D., Krainer, K., and Lucas, S.G 2013b. The Artinskian-Kungurian (upper Lower Permian) calcareous algae and smaller foraminifers of the Yeso Group and San Andres Formation (New Mexico, USA). New Mexico Museum of Natural History and Science, Bulletin, 59:347-348.

Vachard, D. and Moix, P. 2013. Kubergandian (Roadian, Middle Permian) of the Lycian and Aladag Nappes (Southern Turkey). Geobios, 46:335-356. doi:org/ 10.1016/j.geobios.2013.02.002

Vachard, D. and Montenat, C. 1981. Biostratigraphie, micropaléontologie et paléogéographie du Permien de la région de Tezak (Montagnes Centrales d'Afghanistan). Palaeontographica, B, 178(1-3):1-88.

Vachard D., Munnecke A., and Servais T., 2004. New SEM observations of keriothecal walls: implications for the evolution of Fusulinida. Journal of Foraminiferal Research, 34:232-241.

Vachard, D., Oviedo, A., Flores de Dios, A., Malpica, R., Brunner, P., Guerrero, M., and Buitrón, B.E. 1993. Barranca d'Olinalá (Guerrero): une coupe de référence pour le Permien du Mexique central ; étude préliminaire. Annales de la Société Géologique du Nord, $2^{\mathrm{e}}$ série, 2:155-162.

Vachard, D., Perret, M.-F., and Delvolvé, J.-J. 1989b. Algues, pseudo-algues et foraminifères des niveaux bachkiriens dans les secteurs d'Escarra et Aragon Subordan (Pyrénées aragonaises, Espagne). Geobios, 22:697-723.

Vachard D., Pille L., and Gaillot J. 2010. Palaeozoic Foraminifera: systematics, palaeoecology and responses to the global changes. (Les foraminifères paléozoïques: systématique, paléoécologie et réponses aux changements globaux). Revue de Micropaléontologie, 53:209-254.

Vachard, D., Rettori, R., Angiolini, L., and Checconi, A. 2008. Glomomidiella gen. n. (Foraminifera, Miliolata, Neodiscidae): A new genus from the late Guadalupian-Lopingian of Hydra Island (Greece). Rivista Italiana di Paleontologia e Stratigrafia, 114(3):349-361.

Vachard, D., Vidaurre Lemus, M., Fourcade, E., and Requena, J. 2000c. New Early Permian fusulinid assemblage from Guatemala. Comptes Rendus de l'Académie des Sciences de Paris, 331:789-796. 
Vachard, D., Zambetakis-Lekkas, A., Skourtsos, E., Martini, R., and Zaninetti, L. 2003. Foraminifera, algae and carbonate microproblematica from the Late Wuchiapingian/ Dzhulfian (Late Permian) of Peloponnesus (Greece). Rivista Italiana di Paleontologia e Stratigrafia, 109:339-358.

Vdovenko, M.V. 1971. Noviy rid foraminifer iz vizeyskikh vidkladiv veikogo Donbassa. Doprovidi Akademii Nauk Ukrainskoyi RSR, series B, Geologichni, Khimichni ta Biologichni Nauk, 1971, 10:877-879. (In Ukrainian)

Vdovenko, M.V., Rauzer-Chernousova, D.M., Reitlinger, E.A., and Sabirov, A.A. 1993. Spravochnik po sistematike melkikh foraminifer paleozoya. Rossiiskaya Akademiya Nauk, Komissiya po Mikropaleontologii, "'“Nauka”:1-128. (In Russian)

Vennin, E., Vachard, D., and Proust, J.N. 1997. Taphonomic and synecologic study of Tubiphytes. Examples from Tratau and Nizhni-Irginsk buildups from lower Permian of the Urals Mountains. Geobios, 30:635-649.

von Möller, V. 1878. Die spiral-gewundenen Foraminiferen des russischen Kohlenkalks. Mémoires de l'Académie Impériale des Sciences de Saint Pétersbourg, 7th series, 25:1-147.

von Pia, J. 1920. Die Siphoneae verticillatae vom Karbon bis zur Kreide. Abhandlungen der Zoologisch-Botanischen Gesellschaft Wien, 11:1-63 (French translation: Editions Technip:1-236).

von Pia, J. 1937. Die wichtigsten Kalkalgen des Jungpaläozoikums und ihre geologische Bedeutung. Compte Rendu du 2 e Congrès Avancement Etudes de Stratigraphie du Carbonifère, Heerlen 1935, 2:765-856.

Wang, K. 1976. The Foraminifera from the Changhsing Formation in western Guizhou. Acta Paleontologica Sinica, 15:187-195. (In Chinese)
Wang, K.L. 1982. Carboniferous and Permian Foraminifera of Xizang, In Nanjing Institute Geology Paleontology (ed.), Paleontology of Xizang. Scientific Expedition Qinghai-Xizang Plateau, Book IV. Nanjing Institute Geolology Paleontology Academia Sinica, 4:1-32. (In Chinese)

Wang, S.H., Fan, J.S., and Rigby, J.K. 1994. Archaeolithoporella and Tubiphytes: Affinities and palaeoecology in Permian reefs of South China. Science in China, 37:723-743. (In Chinese)

Wang, Y. and Jin, Y. 2000. Permian palaeogeographic evolution of the Jiangnan Basin, South China. Palaeogeography, Palaeoclimatology, Palaeoecology, 160:35-44.

Waters, J.A. 1928. A group of foraminifera from the Canyon division of the Pennsylvanian formation in Texas. Journal of Paleontology, 1:271-275.

Wilde, G.L. 1990. Practical fusulinid zonation: the species concept, with Permian Basin emphasis. West Texas Geological Society Bulletin, 29:5-15, 28-34.

Wilde, G.L. 2006. Pennsylvanian-Permian fusulinaceans of the Big Hatchet Mountains, New Mexico. New Mexico Museum Natural History and Science Bulletin, 38:1-311.

Woszczynska, S. 1987. Foraminifera and ostracods from the carbonate sediments of the Polish Zechstein. Acta Paleontologica Polonica, 32:155-205.

Wray, J.L. 1971. Algae in reefs through time. Proceedings of the North American. Paleontological Convention, Part J:1358-1373.

Yang, X., Liu, J., and Shi, G. 2004. Extinction process and patterns of Middle Permian fusulinaceans in southwest China. Lethaia, 37:139-147.

Zhang, W.T., Chen P.J., and Palmer, A.R. 2003. Biostratigraphy of China. Science Press, Beijing.

Zolotova, V.P. and Baryshnikov, V.V. 1980. Foraminifery kungurskogo yarusa stratotipicheskoi mestnosti (Foraminifers from Kungurian stage stratotype locality). Akademiya Nauk SSSR, Uralskii Nauchnyi Tsentr:72109. (In Russian) 